\title{
Chemical Genetic Analysis of Alepidea amatymbica, a traditional medicine in Africa
}

\author{
Zaccheaus Tabiling
}

A thesis submitted to Victoria University of Wellington in fulfilment of the requirements for the degree of Master of Science

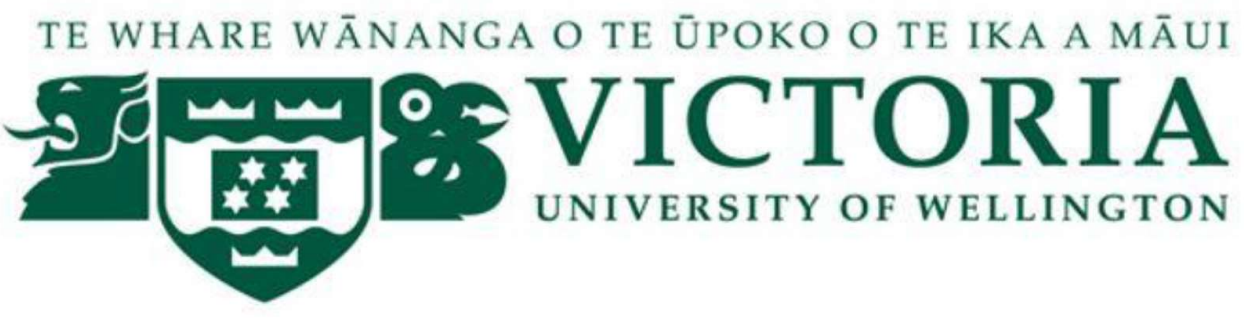

March 2022 


\section{Acknowledgement}

I would like to thank everyone who helped me throughout my thesis.

Andrew, thank you for the opportunity to do research and pursue a master's degree under your supervision. I appreciate all the support, help and guidance.

Helen, thank you for being a good Pasifika colleague and friend, and for all the advice on the project. Jeff, thank you for the blunt but helpful comments, I have learned a lot and I wish you well. Natalie, Cynthia, Tamin and the rest at Chemgen, my thanks to you all.

I would also like to thank Drs. Rob Keyzers, Joe Bracegirdle and Edwina Muleya for providing the extract to work with for my thesis.

My thanks to Stefanie, Clemmie, Ryan and the NZAid Scholarship team here at Victoria University of Wellington for being exceptionally supportive throughout my scholarship.

Mum and Dad, and the rest of family, Lois, Loreen and JohnMc thank you for the prayers and thoughts.

Last but not least, I thank God for seeing me through - “...unto him that is able to do exceeding abundantly above all that we can ask or think.."

Kabiha! 


\section{Abstract}

Natural products are a reliable source of drug leads, with plant natural products contributing some of modern medicine's most important pharmaceuticals. Africa has a rich source of medicinal plants that have not yet been heavily investigated for their therapeutic potential. One such plant is Alepidea amatymbica. The traditional use of A. amatymbica suggests a broad range of bioactivity that has yet to be fully explored. In this thesis, the mechanism of action of A. amatymbica extract and semi-purified compounds were explored using chemical genetics. Using the genetic model Saccharomyces cerevisiae (Baker's yeast), initial phenotypic screening of the crude extract and the semi-purified compound B showed that A. amatymbica is a potential substrate of the pleiotropic drug response system. A genome-wide analysis, using the haploid deletion collection in the $p d r 1 \Delta p d r 3 \Delta$ background, revealed five genes that when deleted showed significantly reduced growth in the presence of $A$. amatymbica. These were Din7, Ura5, Eft2, Glo2 and Get5. The functions of the first four genes are mitochondrial genome stability, de novo pyrimidine biosynthesis, ribosomal translocation and a function relating to glyoxalase system, respectively. The most sensitive gene, Get5, is a member of the guided-entry tail anchored protein (Get) complex involved in tail anchor (TA) protein biosynthesis. Upon further investigation, we found the entire Get family, as well as their interacting chaperones, to be bioactive in A. amatymbica. Further evaluation of the Get pathway was conducted by overexpressing Get3 in $p d r 1 \Delta p d r 3 \Delta$ get $1 \Delta$ and $p d r 1 \Delta p d r 3 \Delta$ get $2 \Delta$ coincidently with $A$. amatymbica extract treatment, where we found that Get3 overexpression confers sensitivity to A. amatymbica. A proteomic analysis using a GFP library was conducted to investigate the mislocalization of TA protein when the cells were treated with A. amatymbica extract, whereby changes in localization of ER proteins Erg9 and Cyb5 were detected. Together, these results identified genes, proteins and pathways involved in buffering the activity of $A$. amatymbica extract. 


\section{Contents}

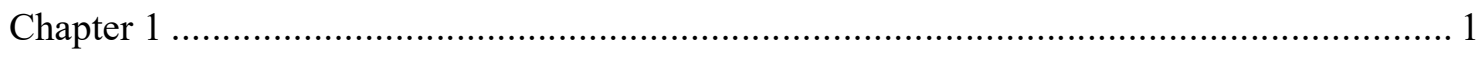

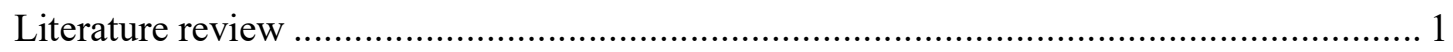

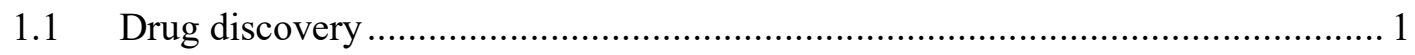

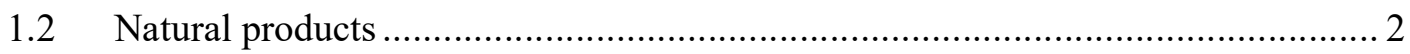

1.3 Natural products research over the years...................................................... 3

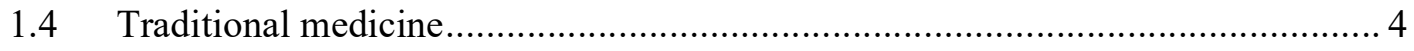

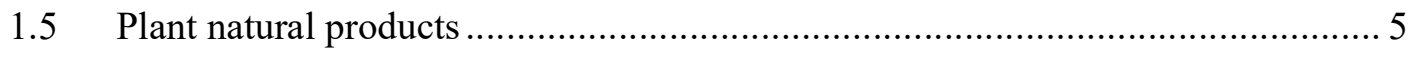

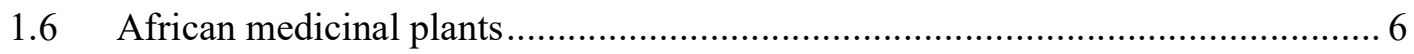

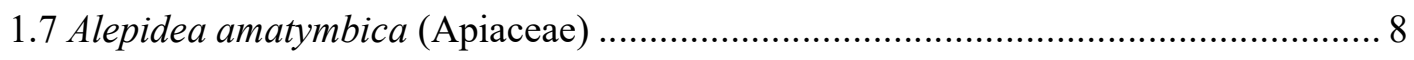

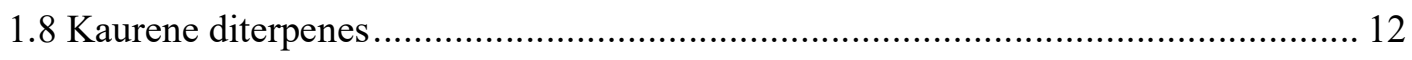

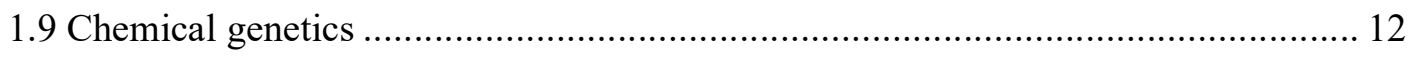

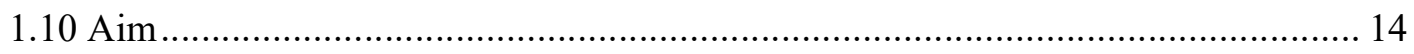

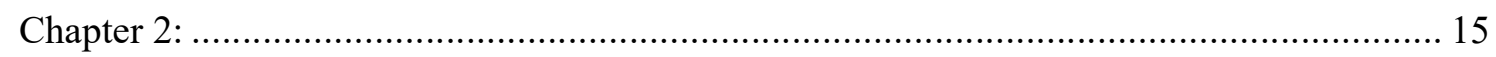

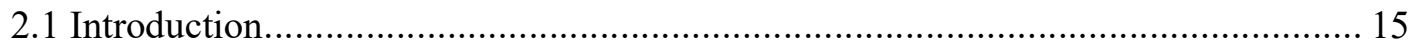

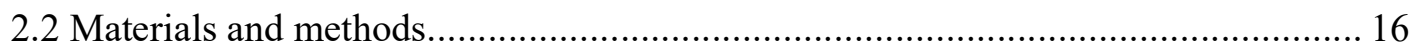

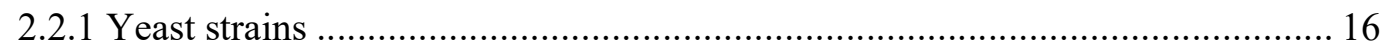

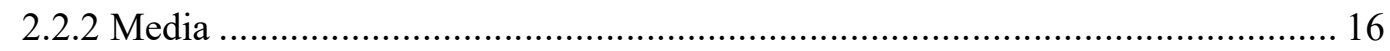

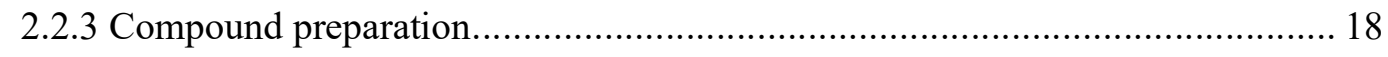

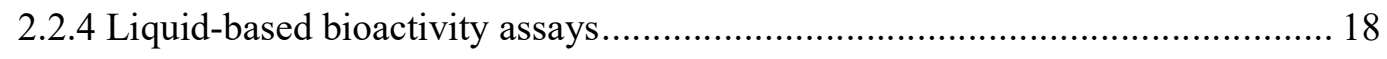

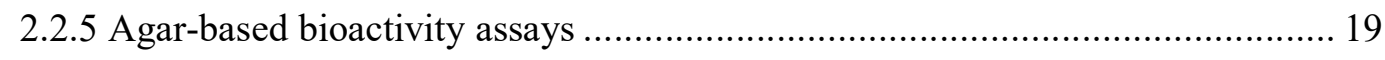


2.2.6 Genome-wide analysis 19

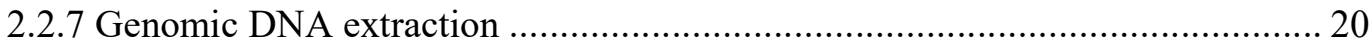

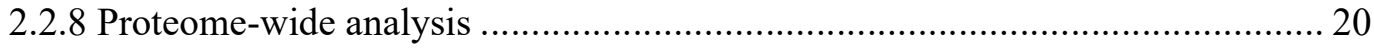

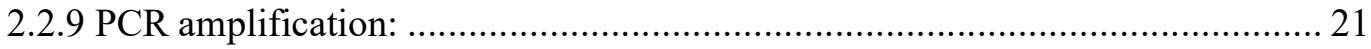

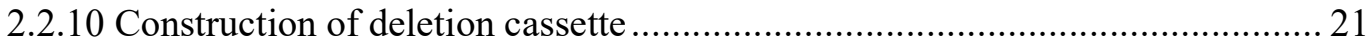

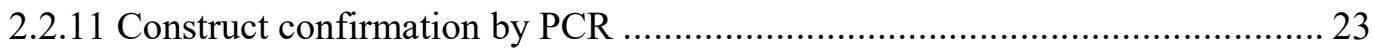

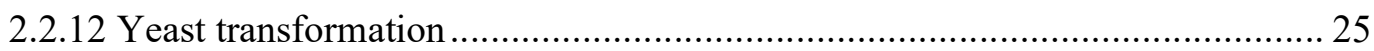

2.2.13 Bacterial plasmid DNA extraction.......................................................... 25

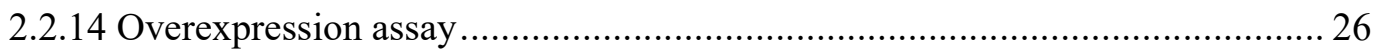

2.2.15 Dose response of compound B and semi-purified compounds ..................... 27

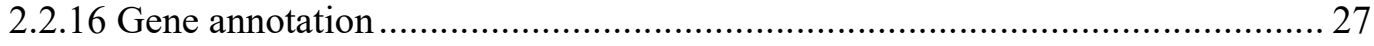

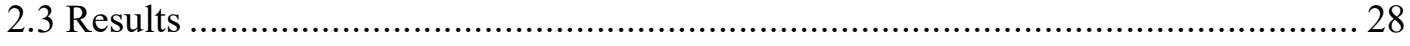

2.3.1 The A. amatymbica extract is a PDR substrate............................................... 28

2.3.2 The A. amatymbica extract was more bioactive in CM media......................... 29

2.3.3 Compound B is potent in liquid media .................................................... 30

2.3.4 The extract and compound B are bioactive in agar .................................... 31

2.3.5 Optimisation of A. amatymbica extract for genome-wide analysis in agar ........ 32

2.3.6 The A. amatymbica extract affects various biological processes ..................... 33

2.3.7 Functional annotation of genes altered by A. amatymbica extract ................... 35

2.3.8 Extract sensitivity in all members of the guided-entry tail anchored protein

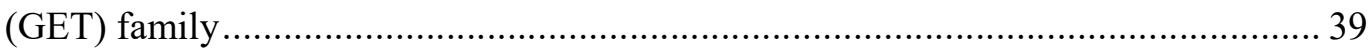


2.3.9 Compound B is less potent against guided-entry tail anchored protein (GET)

deletion strains

2.4.0 Overexpression of GET3 in get $1 \Delta$ or get $2 \Delta$ increases extract bioactivity 42

2.4.1 Get3 overexpressed in $p d r 1 \Delta p d r 3 \Delta$ get $1 \Delta$ and $p d r 1 \Delta p d r 3 \Delta$ get $2 \Delta$ background is sensitive to A. amatymbica on agar 45

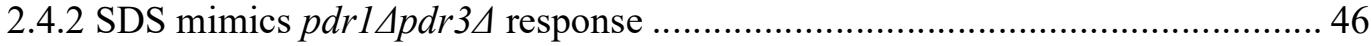

2.4.3 A. amatymbica extract does not affect GET mutants................................... 47

2.4.5 A. amatymbica affects ERG9 and CYB5 localisation ................................. 49

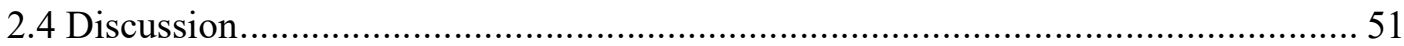

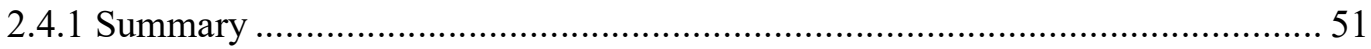

2.4.2 A. amatymbica as a PDR substrate ......................................................... 51

2.4.3 A. amatymbica potentially affects guided entry for tail-anchored protein (GET)53

2.4.4 Potential function in the TRC40 pathway................................................... 55

2.4.5 Potential function in antioxidant activity .................................................... 56

2.4.6 Potential anti-cancer activity of A. amatymbica .......................................... 57

2.4.7 Potential function for A. amatymbica in lipid metabolism ............................ 59

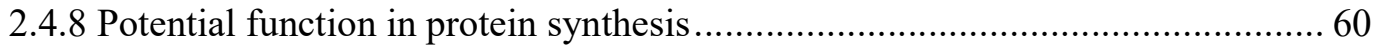

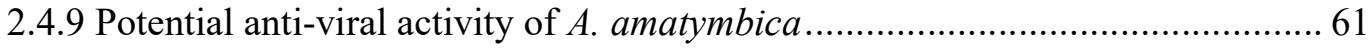

2.5.0 Potential variation in the bioactivity of $A$. amatymbica .................................. 62

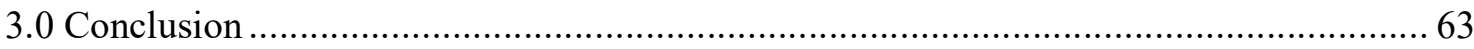

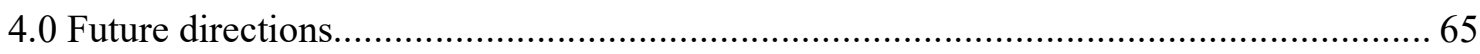

4.1 Genome-wide screen of gene deletion in a PDR-positive background ...................... 65 


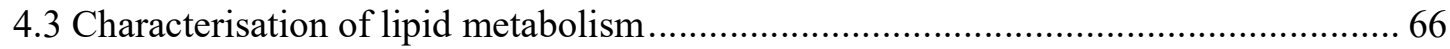

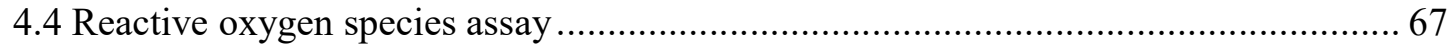

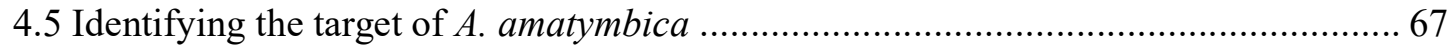

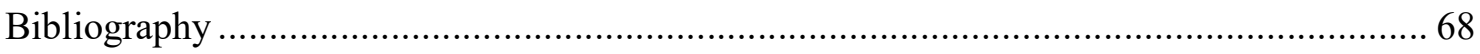




\section{List of figures}

Figure 1.1: Images of Alepidea amatymbica ........................................................... 9

Figure 1.2: Chemical structures of kaurene-type diterpenoids in Alepidea amatymbica ....... 10

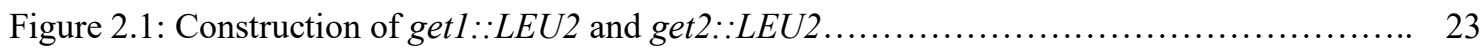

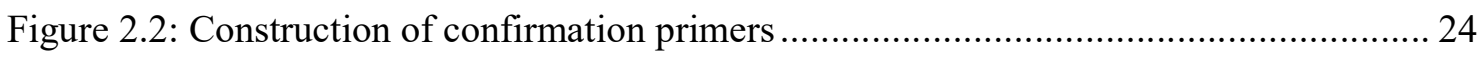

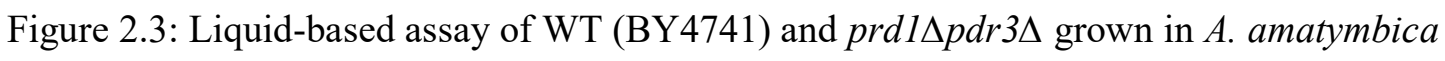

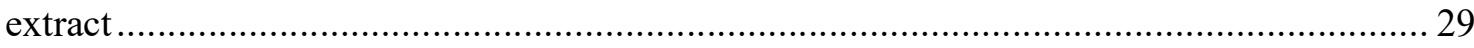

Figure 2.4: Liquid-based bioactivity assay of $p d r 1 \Delta p d r 3 \Delta$ yeast strain in different media ... 30

Figure 2.5: Liquid-based bioactivity assay of $p d r 1 \Delta p d r 3 \Delta$ in response to different semi-

purified fractions derived from the $A$. amatymbica extract......................................... 31

Figure 2.6: Agar-based dose response assay of the A. amatymbica extract and semi-purified

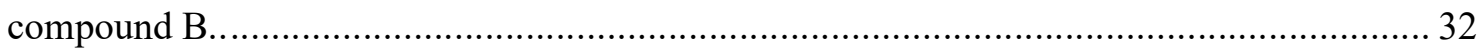

Figure 2.7: Optimisation of $A$. amatymbica extract treatment for genome-wide analysis of

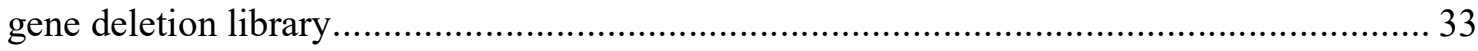

Figure 2.8: Sensitivity of 4,270 haploid gene deletion strains to the A. amatymbica extract.. 34

Figure 2.9: Low-throughput growth analysis confirms 5 gene deletion strains as sensitive to

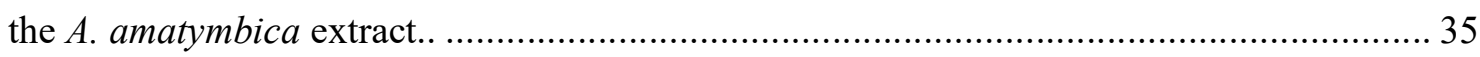

Figure 2.10: Transcriptional network regulating the five gene deletions sensitive to the $A$.

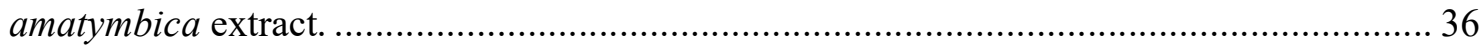

Figure 2.11: Spatial analysis for functional enrichment (SAFE) reveals enrichment for vesicle

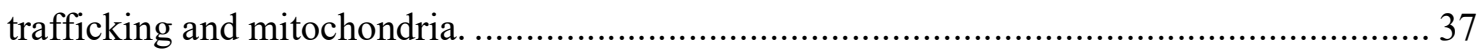

Figure 2.12: GO enrichment analysis of 5 genes sensitive to $A$. amatymbica extract........... 39

Figure 2.13: Sensitivity of genes involved in the guided entry tail anchored protein (GET)

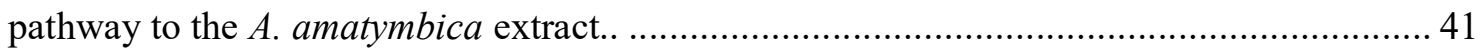


Figure 2.14: Sensitivity of genes involved in the guided entry tail anchored protein (GET)

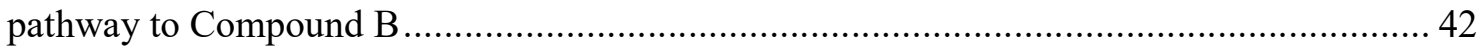

Figure 2.15: Construction of the GET1::LEU2 and GET2::LEU2 deletion cassettes............ 44 Figure 2.16: Confirmation of transformation of (A) get $1:: L E U 2$ and (B) get $2:: L E U 2$ cassettes

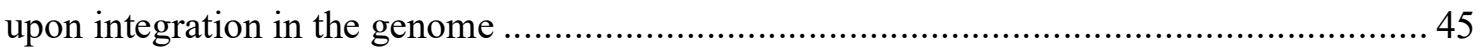

Figure 2.17: Over expressing Get3 in the presence of $A$. amatymbica on agar................... 46 Figure 2.18: Wild-type (BY4741) yeast cells treated with $0.003 \%$ SDS mimics $p d r 1 \Delta p d r 3 \Delta$

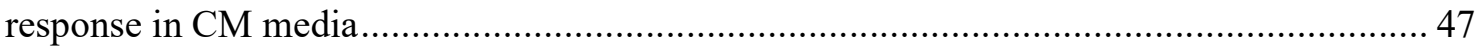

Figure 2.19: GET pathway is not affected by A. amatymbica treatment ............................ 48

Figure 2.20: ERG9 and CYB5 are affected by A. amatymbica treatment ........................... 50 


\section{List of tables}

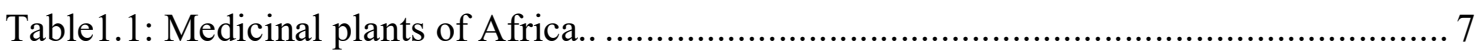

Table1.2: Compounds isolated from A. amatymbica ..................................................... 11

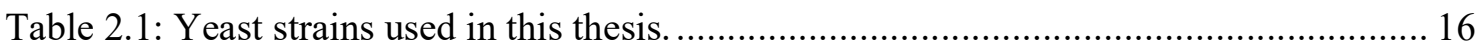

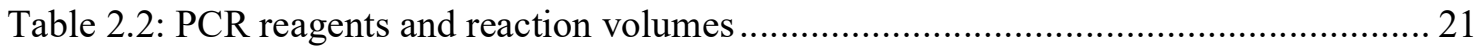

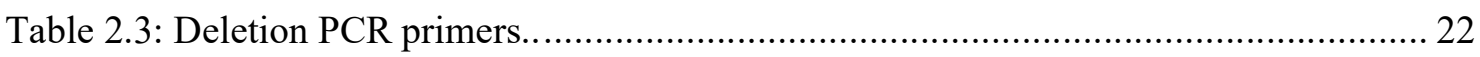

Table 2 4: PCR conditions for the deletion of GET1 and GET2 …............................... 22

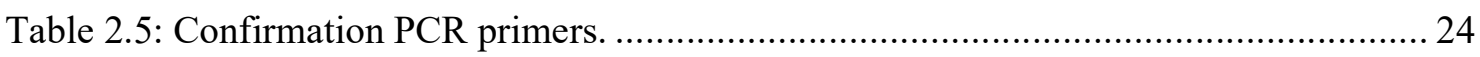

Table 2.6: PCR conditions for the confirmation of get $1::$ LEU2 and get $2::$ LEU2 $\ldots \ldots \ldots \ldots \ldots \ldots . . . . . .25$

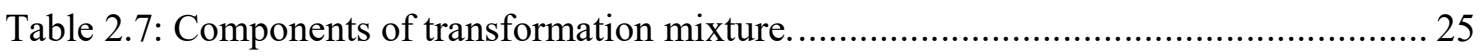

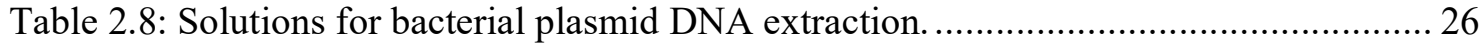

Table 2.9: Annotation of the genes that were found to be sensitive to A. amatymbica extract.. 38 


\begin{tabular}{|c|c|}
\hline \multicolumn{2}{|c|}{ Abbreviations } \\
\hline $\mathrm{ABC}$ & ATP-Binding Cassette \\
\hline $\mathrm{CM}$ & Complete Minimum \\
\hline DMA & Deletion Mutant Array \\
\hline DMSO & Dimethyl Sulfoxide \\
\hline ER & Endoplasmic Reticulum \\
\hline GET & Guided entry tail anchored protein \\
\hline GFP & Green Fluorescent Protein \\
\hline GO & Gene Ontology \\
\hline HTS & High-Throughput Screen \\
\hline NP & Natural product \\
\hline ORF & Open Reading Frame \\
\hline PDR & Pleiotropic Drug Resistance \\
\hline $\mathrm{SC}$ & Synthetic Complete \\
\hline SD & Synthetic Dropout \\
\hline TA & Tail anchored (protein) \\
\hline WT & Wild Type \\
\hline NCE & New chemical entities \\
\hline TOR & Target of rapamycin \\
\hline YPD & Yeast extract peptone dextrose \\
\hline
\end{tabular}




\section{Chapter 1}

\section{Literature review}

\subsection{Drug discovery}

New drugs are continually being needed to address unmet medical needs in our healthcare systems. For this reason, there is a perpetual need for drug discovery and development (Sinha \& Vohora, 2018). Drug discovery is both a resource and time-consuming process. Generally, the process involves target identification, hit identification, lead generation and optimization and finally the identification of a candidate for further development (Mohs \& Greig, 2017).

Drug discovery of natural products is broadly distinguished based on three different approaches. In a bioactive-guided screening approach, a known synthetic or semi-purified compound or a crude extract is screened for biological activity using cell-based assays where the cellular drug target is unknown. This is done early in the experimental process and often involves screening a large number of compounds using defined biochemical assays on biologically relevant surrogates to predict the response of the organism (Clemons, 2004). A bioactive hit prompts further study to determine the cellular target and mechanism of action (Lee et al., 2012).

In contrast, a chemical screening approach does not begin with investigating biological activity. Instead, the extract is screened for chemical novelty before a biological assay is done. For this, structural elucidation is done using sophisticated analytical methods like nuclear magnetic resonance (Bracegirdle et al., 2020) and mass spectrometry (Wohlleben et al., 2016). Presently, large databases exist where mass spectra data can be compared to determine if what is obtained is already known. In the third approach, target-oriented screening, a known molecular target is used to predict compounds that are able to interact with the target. In this 
case, the researcher has a pathology of interest in mind and the drug is meant to hit the molecular target involved in that pathology (Wohlleben et al., 2016).

\subsection{Natural products}

Natural products are chemical entities formed by living organisms, with pharmacological properties that can be used in drug discovery and design (Mathur \& Hoskins, 2017). The molecules are not essential for growth and reproduction but generally function in assisting and improving the survival of the organism such as chemical defence against predators (Baker et al., 2007). Many of these molecules are intermediates derived from basic biosynthetic pathways that have undergone modifications in response to abiotic and biotic stress (Baker et al., 2007). As a result, many secondary metabolites possess drug-like properties that have contributed to drug discovery (Clardy \& Walsh, 2004).

The testament of this is seen in today's pharmacopeia. The discovery of penicillin in 1928 began an era of modern drug discovery programmes. From 1940 onwards, many microorganisms were being screened for bacterial metabolites (Baltz, 2008). Many of these have become the mainstay of drug prescriptions in antibacterial therapeutics where they account for the majority of antibiotics used in clinics. These drugs include erythromycin, streptomycin, tetracycline and vancomycin (Katz \& Baltz, 2016). Most successful new drugs, drug leads and new chemical entities (NCE) were sourced from natural products. It is estimated that prior to the era of genomics and high-throughput screening, more than $80 \%$ of drugs were derived or inspired by natural products (Harvey, 2008). More recently, in the period spanning 1981 to $2014,38.1 \%$ of all drugs approved by the US Food and Drug Administration were either unaltered natural products, natural products derivatives or they were synthetics with natural products pharmacophore (Newman \& Cragg, 2016). In 2019, 28\% of NCE's were derived from natural products while of all small molecules approved between 1981 and 2019, 
natural products accounted for 36.3\% (Newman \& Cragg, 2020). This shows that natural products are a reliable source of new drugs or drug leads.

\subsection{Natural products research over the years}

Towards the end of the 1990 s, approximately $80 \%$ of drugs were either natural products or natural product analogues (Li \& Vederas, 2009). However, natural product research began to decline for several reasons. Regulatory concerns regarding access to biodiversity (based on the UN convention on biodiversity) thereby causing difficulty in patenting natural productsbased drugs (Harrison, 2014), incompatibility with high through-put drug screening and discovery processes (Harvey, 2008), the high rediscovery rate of known compounds (ZarinsTutt et al., 2016), and complex natural product structures leading to difficult syntheses (Harvey et al., 2015) have contributed to the waning interest, particularly in the pharmaceutical industry.

Consequently, focus began to shift towards high-throughput synthetic drug discovery utilizing man-made chemicals instead of natural ingredients (Li et al., 2019; Thomford et al., 2018). Unfortunately, this strategic shift gave an overall reduction in novel lead compounds, leading to a substantial decline in new drug approval (Li \& Vederas, 2009). Emphasis was subsequently made for more random screening, with assumptions that the low hanging fruits have all been picked and only through larger more rigorous screening can the few remaining be harvested (Monciardini et al., 2014). But as Newman and Cragg (2007) observed, this was also met with limited success with very few lead structures and drug candidates discovered over a two decade period (Newman \& Cragg, 2007). The lack of success is attributable to synthetic compounds occupying a limited chemical space unlike natural products that have higher chemical diversity and are evolutionary optimized for biochemical interactions such as binding to specific target proteins or biomolecules that are pertinent to a biological function (Rosén et al., 2009). This outcome suggested the diversity within biologically relevant 
'chemical space' might be more important than library size, prompting a re-shift towards diversity-oriented syntheses in order to improve the hit rates (Lenci et al., 2018). This inevitably brings natural products back to the forefront of drug discovery since they provide good models for chemically-diverse syntheses.

Many of the concerns associated with natural products research have been circumvented with technological advancements in analytical techniques leading to improvements in natural products compatibility in high-throughput screening, isolation, dereplication and lead optimisation, in addition to improvements in chemical syntheses (Atanasov et al., 2021; Li \& Vederas, 2009; Thomford et al., 2018). Furthermore, the emergence of genome mining and engineering have reinvigorated the field (Atanasov et al., 2021).Thus, there has been a resurgence in the use of natural products for new drug discovery and natural products research is yet again gaining traction in the field (Li et al., 2019).

\subsection{Traditional medicine}

The use of natural products in medicine dates back to antiquity, with the earliest use of medicinal plant recorded in the Paleolithic age some 60,000 years ago (Fabricant \& Farnsworth, 2001). The World Health Organization defines traditional medicine as any nonWestern medical practice (Karunamoorthi et al., 2013). The Unani and Ayurvedic medicine existed 2,500 years ago in Greece and India (Ravishankar \& Shukla, 2007; Yuan et al., 2016). Traditional medicines in Asia have flourished since 221BC (Wang et al., 2020; Yuan et al., 2016). These, and other ethno-medicines employ various natural products in the treatment of diseases. Examples of these are Cupressus sempevirens (cypress oil), cedar oils (Cedrus sp.), licorice oils (Glycyrrhiza glabra), myrrh (Commiphora sp.), poppy juice (Papaver somniferum), Spiraea ulmaria and cinchona (Patridge et al., 2016; Permin et al., 2016). 
Of these, the opium plant, Papaver somniferum, is known for the pharmacologicallyactive compound - morphine. The drug was first isolated in 1805 by Friedrich Sertuner, setting the stage for the beginning of drug discovery (Joo, 2014). Subsequently, other active compounds were uncovered including for instance in 1820, the antimalarial quinine alkaloids which interestingly followed from the traditional use of the cinchona plant from which it was isolated (Dvorkin-Camiel \& Whelan, 2008). Other drugs were later isolated from their medicinal plant sources. Most notable of these is the antimalarial drug artemisinin, which was derived from the Chinese medicinal plant Artemisia annua in 1972, and whose discovery led to the 2015 Nobel Prize in Medicine (Su, 2015).

\subsection{Plant natural products}

Plants have been valuable sources of new drugs. It is known that plants have been used as medicine for millennia. Indeed many of the drugs in use today have been derived from plant natural products (Newman \& Cragg, 2020). However, the scientific breakthrough in plant based natural products discovery perhaps occurred with the 1785 discovery of digoxin from Digitalis purpurea by William Withering (Krikler, 1985). Discovery of chemical compounds from other Digitalis spp. followed with the isolation of acetyldigoxin, digitalin, digitoxin, deslanoside, and lanatosides A, B and C from D. lanata (Lahlou, 2013).

This initiated research interests into other medicinal plants, leading to the discovery of many other plant based natural products. As mentioned earlier, this includes: morphine, quinine alkaloids and artemisinin. Initially, efforts were limited to identifying and isolating natural products from their plant sources, and later synthesis was employed to increase production and ease down costs of producing these natural products. The first of such compounds to have been synthesized was salicylic acid in 1853 (Wood, 2015). Plant-derived natural compounds have since become indispensable for modern pharmacotherapy, with prominent examples in the field 
of anticancer agents. This includes paclitaxel that was derived from the Pacific yew (Taxus) tree, vincristine and vinblastine that came from periwinkle, and camptothecin isolated from Camptotheca acuminata Decne (Kingston \& Newman, 2002).

\subsection{African medicinal plants}

The African continent is home to a rich source of plant diversity containing about $25 \%$ of the world's higher plants (van Wyk, 2008). Of these, around 5,400 medicinal plant taxa have been recorded with over 16,300 medicinal uses (Neuwinger, 2000). With high regular usage of traditional medicine in $80 \%$ of the continental population and rather costly western medicine option (Arnold et al., 2002; Okoli \& Mtunzi, 2017; Wyk \& Gericke, 2000), Africa has an informal medicine market that is worth potentially millions of dollars (Cunningham et al., 1988). Despite its popularity, there is little scientific research being done on these traditional medicines leading to a generally poor understanding of the science behind these traditional medicine. Over the years, the recognition of the importance of natural resources towards socioeconomic development (Geldenhuys \& Wyk, 2002) has reignited scientific interests in these medicinal plants.

This has led to ethnobotanical and ethnomedical surveys on commercially important plants of Africa documenting not only their traditional uses but also their developmental challenges to commercialization. Other studies have sought to investigate the bioactivities specific to medicinal plants of interest. A subset of these plants are shown in the table below. 


\begin{tabular}{|c|c|c|c|c|}
\hline $\begin{array}{l}\text { Medicinal } \\
\text { plant }\end{array}$ & $\begin{array}{l}\text { Bioactivity or } \\
\text { traditional use }\end{array}$ & Constituents & Countries & Reference \\
\hline Prunus africana & $\begin{array}{l}\text { Prostate gland } \\
\text { hypertrophy }\end{array}$ & $\begin{array}{l}\text { Sterols, } \\
\text { triterpenes, n- } \\
\text { docosanol }\end{array}$ & $\begin{array}{l}\text { Cameroon, } \\
\text { Kenya, } \\
\text { Madagascar }\end{array}$ & $\begin{array}{l}\text { (Abdullahi, } \\
\text { 2011) }\end{array}$ \\
\hline $\begin{array}{l}\text { Acacia } \\
\text { ataxacantha }\end{array}$ & $\begin{array}{l}\text { Cough, yellow } \\
\text { fever }\end{array}$ & - & Nigeria & $\begin{array}{ll}\text { Dambatta } & \& \\
\text { Aliyu, 2012) } & \end{array}$ \\
\hline $\begin{array}{l}\text { Enantia } \\
\text { chlorantha }\end{array}$ & Hepatitis & Protobeberine & Cameroon & $\begin{array}{l}\text { (Fokunang et } \\
\text { al., 2011) }\end{array}$ \\
\hline $\begin{array}{l}\text { Equisetum } \\
\text { arvense }\end{array}$ & Inflammation & - & South America & $\begin{array}{l}\text { (Madikizela et } \\
\text { al., 2017) }\end{array}$ \\
\hline Artemisia afra & $\begin{array}{l}\text { Sedative, CNS } \\
\text { related ailments }\end{array}$ & Monoterpenes & South Africa & $\begin{array}{l}\text { (Stafford et al., } \\
\text { 2005) }\end{array}$ \\
\hline $\begin{array}{l}\text { Agathosma } \\
\text { betulina }\end{array}$ & $\begin{array}{l}\text { antispasmodic, } \\
\text { antipyretic, } \\
\text { cough remedy, } \\
\text { diuretic }\end{array}$ & $\begin{array}{l}\text { limonene, } \\
\text { menthone, } \\
\text { diosphenol,1- } \\
\text { pulegone }\end{array}$ & South Africa & $\begin{array}{l}\text { (Street \& } \\
\text { Prinsloo, 2013) }\end{array}$ \\
\hline $\begin{array}{l}\text { Dalbergia } \\
\text { melanoxylon }\end{array}$ & Rashes & - & South Africa & $\begin{array}{l}\text { (Tshikalange et } \\
\text { al., 2016) }\end{array}$ \\
\hline $\begin{array}{l}\text { Alepidea } \\
\text { amatymbica }\end{array}$ & $\begin{array}{l}\text { Antimicrobial, } \\
\text { anti-fungal }\end{array}$ & Diterpenes & South Africa & $\begin{array}{l}\text { (Afolayan \& } \\
\text { Lewu, 2009) }\end{array}$ \\
\hline $\begin{array}{l}\text { Gunnera } \\
\text { perpensa }\end{array}$ & $\begin{array}{l}\text { Anti-bacterial, } \\
\text { anti-fungal }\end{array}$ & - & South Africa & $\begin{array}{l}\text { (Buwa \& van } \\
\text { Staden, 2006) }\end{array}$ \\
\hline $\begin{array}{l}\text { Combretum } \\
\text { micranthum }\end{array}$ & $\begin{array}{l}\text { Anti-bacterial, } \\
\text { antifungal }\end{array}$ & $\begin{array}{l}\text { Tannins, } \\
\text { flavonoids, } \\
\text { terpenoids, } \\
\text { stilbenoids }\end{array}$ & South Africa & $\begin{array}{l}\text { (Eloff et al., } \\
2008)\end{array}$ \\
\hline $\begin{array}{l}\text { Gladiolus } \\
\text { quartinianus }\end{array}$ & Anti-cancer & - & Cameroon & $\begin{array}{l}\text { (Kuete et al., } \\
2013 \text { ) }\end{array}$ \\
\hline $\begin{array}{l}\text { Elephantorrhiza } \\
\text { burkei }\end{array}$ & Anti-bacterial & - & South Africa & $\begin{array}{l}\text { (Madikizela et } \\
\text { al., 2017) }\end{array}$ \\
\hline
\end{tabular}

Table 1.1: Medicinal plants of Africa. The bioactivity or traditional use, the bioactive components, and geographic location indicated for each plant. -, unknown.

The use of African plants in traditional medicine can be traced as far back as 2000BC (Busia, 2005). In South Africa, like in many parts of Africa, traditional medicine represents a hidden informal economy that is less supported than its western counterpart (Cunningham et 
al., 1988). Nevertheless, South Africa has similarities with Japan in its dual system of 'western' and indigenous medicine (Busia, 2005).

It has been observed that many medicinal plants in Africa exhibit bioactivities relating to anti-inflammation and immune modulation (Gqaleni et al., 2012; Madikizela et al., 2017; Patel et al., 2018), antimicrobial and antifungal (Mulaudzi et al., 2009; Ngouana et al., 2011; Okoli \& Mtunzi, 2017; Sunday Uko et al., 2019), anti-cancer (Kuete et al., 2013; Mbaveng et al., 2017; Otang et al., 2014) as well as anti-diabetic (Ocloo \& Dongdem, 2011; Odeyemi \& Bradley, 2018).

\subsection{Alepidea amatymbica (Apiaceae)}

The plant in this study Alepidea amatymbica Eckl. \& Zeyh (also known as Alepidea aquatica Kuntze, Eryngium amatymbica, kalmoes; Iqwili; ikhathazo (Zulu) and tinsel flower),

is a herbaceous plant found throughout the African continent but more commonly in the grasslands of the Eastern and South African region (Thayer \& Austin, 1992). It is one of 27 species of the genus Alepidea, and one of six in the genus known to be used as traditional medicine (Lahlou, 2013). The plant is robust and erect with dark green leaves arising from a single or branched rhizome that has a toothed and bristle margin. It grows up to two metres in height and carries a flowering stalk holding numerous small flowers arranged in dense, rounded heads (Fig. 1.1) (Afolayan \& Lewu, 2009).

Its traditional medicinal use covers a range of general treatments such as cold, chest pain, asthma, influenza, diarrhoea, abdominal cramp, sore throat and rheumatism (Wintola \& Afolayan, 2014). An infusion or decoction of the bark is taken as cure to these mentioned conditions (Maroyi, 2008). Alternatively, the rhizomes and roots are chewed or smoked (Afolayan \& Lewu, 2009). Its use has been recorded in six countries across Southern and 
Eastern Africa, including South Africa, Swaziland, Lesotho, Zimbabwe Kenya and Ethiopia. It is particularly popular in South Africa where it is commercially traded under the Zulu name 'Ikhathazo' (Afolayan \& Lewu, 2009). Preliminary studies on the extract of A. amatymbica indicate bioactivity relating to anti-microbial, anti-fungal, anti-helminthic, anti-plasmodial, anti-hypertensive, anti-inflammatory and anti-viral activities (Wintola \& Afolayan, 2014). In traditional medicine, the extract is highly regarded as a remedy for respiratory tract infections, asthma, sore throat, gastrointestinal complaints, fever, rheumatism, bleeding wounds, and headache as well as activity against HIV (Louvel et al., 2013). However, there is a dearth in scientific studies investigating the underlying bioactivity for drug development beyond these folklore uses (Wintola \& Afolayan, 2014). For instance, antifungal studies conducted on Candida albicans, Aspergillus flavus and, Aspergillus niger yielded inconclusive results (Muleya et al., 2017).

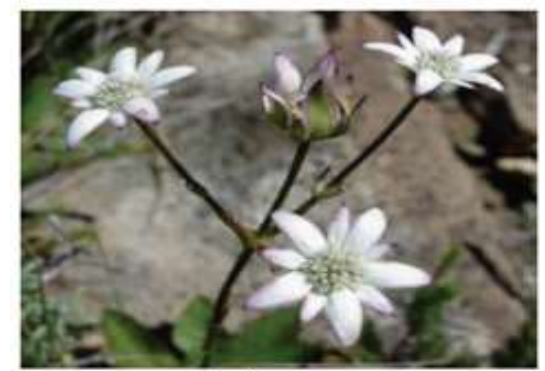

(A)

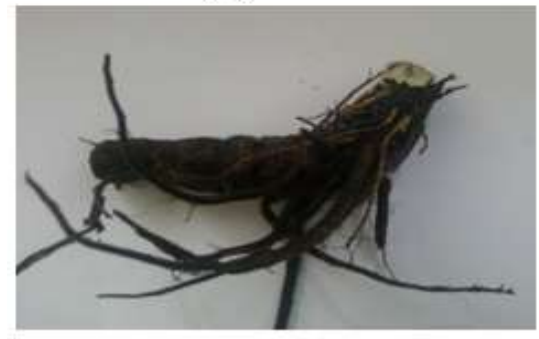

(c)

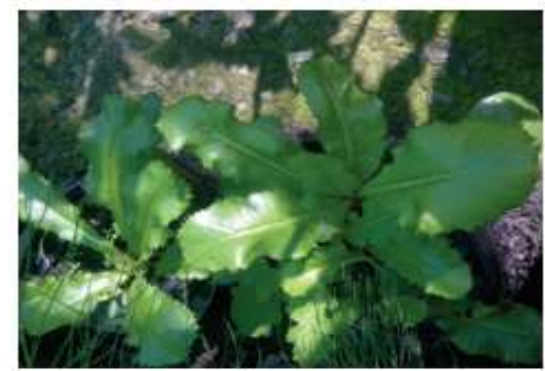

(B)

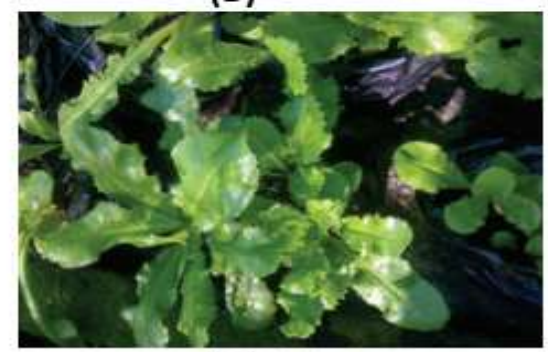

(D)

Figure 1.1: Images of Alepidea amatymbica (A-B) In its natural habit, (C) as a dried rhizome (D) growing in the nursery (Afolayan \& Lewu, 2009). 


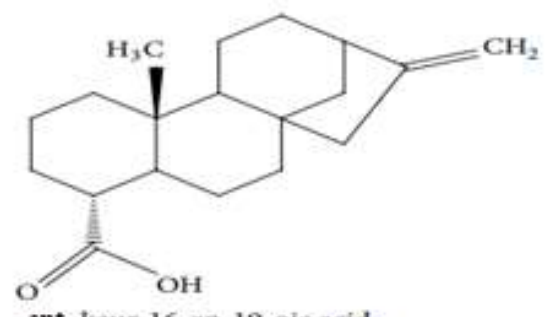

ent-kaur-16-en-19-oic acid

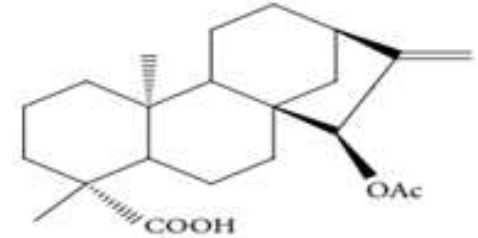

15 $\beta$-Acetoxy-(-)-kaur-16-en-19-oic acid

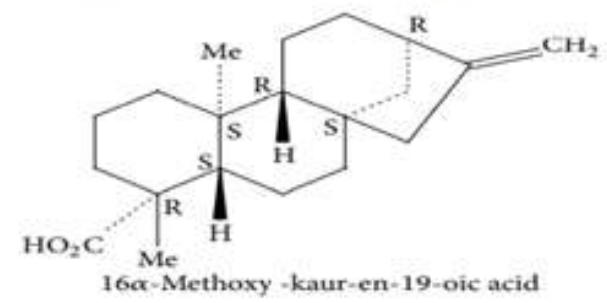

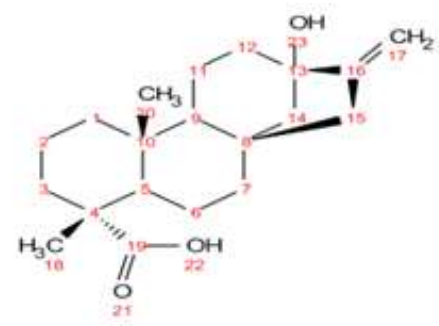

13-hydroxy-kaur-16-en-19-oicacid

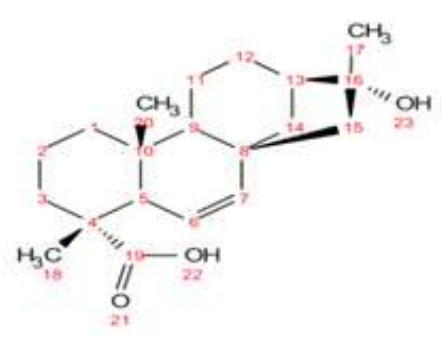

16-hydroxy-kaur-6-en-19-oic-acid

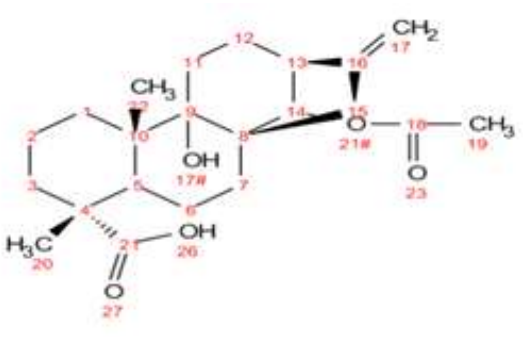

14-acetoxy-ent-kaur-16-en-19-oic acid

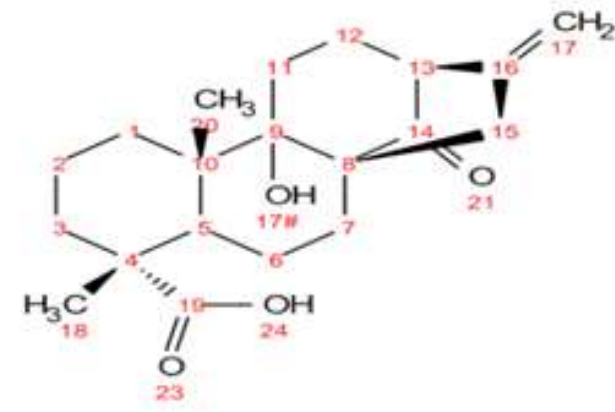

14-oxokaur-16-en-19-oic acid

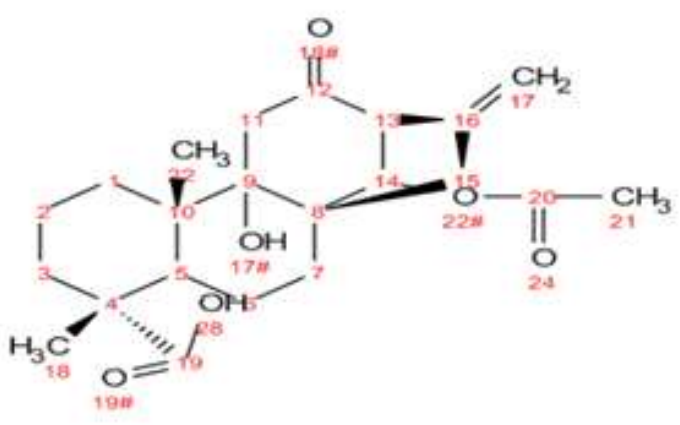

14-acetoxo-12-oxokaur-16-en-19-oic acid

Figure 1.2: Chemical structures of kaurene-type diterpenoids in Alepidea amatymbica (Afolayan \& Lewu, 2009; Muleya et al., 2017). 


\begin{tabular}{|c|c|c|c|}
\hline Phytochemicals & Compound & Plant source & Reference \\
\hline \multirow[t]{9}{*}{$\begin{array}{l}\text { Terpenes (kaurene- } \\
\text { type diterpenes) }\end{array}$} & $\begin{array}{l}\text { ent-9, (11)-dehydro- } \\
\text { 16-kauren-19-oic acid }\end{array}$ & Rhizomes, root & $\begin{array}{l}\text { (Rustaiyan \& Sadjadi, } \\
\text { 1987) }\end{array}$ \\
\hline & $\begin{array}{l}\text { ent-16-kauren-19-oic } \\
\text { acid }\end{array}$ & Dried rhizomes & $\begin{array}{l}\text { (Rustaiyan \& Sadjadi, } \\
\text { 1987) }\end{array}$ \\
\hline & $\begin{array}{l}\text { Wedelia seco- } \\
\text { kaurenolide }\end{array}$ & Dried rhizomes & $\begin{array}{l}\text { (Rustaiyan \& Sadjadi, } \\
\text { 1987) }\end{array}$ \\
\hline & 13-acetoxy & Dried rhizomes & $\begin{array}{l}\text { (Rustaiyan \& Sadjadi, } \\
\text { 1987) }\end{array}$ \\
\hline & $\begin{array}{l}\text { 13-hydroxy-kaur-16- } \\
\text { en-oicacid }\end{array}$ & Dried roots & (Muleya et al., 2017) \\
\hline & $\begin{array}{l}\text { 16-hydroxy-kaur-6-en- } \\
\text { 19-oic-acid }\end{array}$ & Dried roots & (Muleya et al., 2017) \\
\hline & $\begin{array}{l}\text { 14-acetoxy ent-kaur- } \\
\text { 16-en-19-oic acid }\end{array}$ & Dried roots & (Muleya et al., 2017) \\
\hline & $\begin{array}{l}\text { 14-oxo-16-en-19-oic } \\
\text { acid }\end{array}$ & Dried roots & (Muleya et al., 2017) \\
\hline & $\begin{array}{l}\text { 14-acetoxo-12- } \\
\text { oxokaur-16-en-19-oic } \\
\text { acid }\end{array}$ & Dried roots & (Muleya et al., 2017) \\
\hline Phenolic acid & Phenolic acid & Rhizomes & (Louvel et al., 2013) \\
\hline Rosmarinic acid & $\begin{array}{l}3^{\prime} \\
-\mathrm{O}-\beta \text {-d- } \\
\text { Glucopyranosyl } \\
\text { rosmarinic acid }\end{array}$ & Rhizomes & (Louvel et al., 2013) \\
\hline
\end{tabular}

Table 1.2: Compounds isolated from $A$. amatymbica 


\subsection{Kaurene diterpenes}

It has been hypothesized that the bioactivities of $A$. amatymbica can be attributed to kaurene-type diterpenoids and their derivatives (Fig. 1.2; Table 1.2) which constitute 11.8\% of rhizome and root dry mass (Wintola \& Afolayan, 2014). However, most of these compounds have not been tested individually (Afolayan \& Lewu, 2009).

A study of five diterpenic acids isolated from A. amatymbica showed all were antimicrobial (Muleya et al., 2017). These diterpenoids (13-hydroxy-16-kauren-19-oic acid, 16-hydroxy-kaur-6-en-19-oic acid, 14-acetoxy ent-kaur-16-en-19-oic acid, 14-oxokaur-16-en19-oic acid, and 14-acetoxo-12-oxokaur-16-en-19-oic acid), inhibited the growth of Psuedomonas aeruginosa and Enterococcus faecalis. One of them, 14-acetoxo-12-oxokaur16-en19-oic acid, showed potency against Staphylococcus aureus, E. faecalis and Escherichia coli, and a relatively high lipoxygenase inhibition activity. The isolated diterpenoids were also shown to be toxic to cancer cell lines. This suggests that the diterpenic acids might be responsible for the biological activities of A. amatybica extract in traditional medicine.

\subsection{Chemical genetics}

In drug discovery, understanding the mechanism of action of a bioactive compound or extract is important (Parsons et al., 2004). Chemical genetics is an approach used to study genes involved in extract/compound bioactivity (Cong et al., 2012).

In combination with a tractable model organism and molecular toolkit, chemical genetics is a powerful technique in deducing cellular drug targets (Cong et al., 2012). One such model organism is the unicellular eukaryote Saccharomyces cerevisiae (Baker's yeast), where a genome-wide collection of defined gene deletion mutants is exposed to a compound and the fitness of individual mutants is measured to determine the contribution of each gene to 
bioactivity. Gene deletions that render cells hypersensitive to a drug/extract identify the importance of that gene and associated pathways to the mode of action (Giaever \& Nislow, 2014). This is based on the concept that the primary effect of a drug is to bind a gene product in a manner that inhibits its function (O'Connor et al., 2011). Hence by deleting the corresponding gene target, the primary effect of the drug can be mimicked (O' Connor et al., 2011). Since it is a genome-wide analysis, the technique provides an unbiased view of the cellular response (Piotrowski et al., 2017). Overall, the mode of action of thousands of compounds and extracts has been elucidated using chemical genetic analyses in yeast (Piotrowski et al., 2017)

The use of yeast as a chemical genetic tool has had a profound impact in the field due to its known genome and available genomic reagents and tools (Piotrowski et al., 2017). Libraries comprised of deletions of non-essential genes, knockdowns of essential genes, overexpressions of non-essential and essential genes, and fluorescently tagged non-essential and essential proteins are all vital tools to genome-wide analyses in yeast. Not only is the organism amenable to genetic manipulations, it also has a relatively short doubling time and is cheap and can be easily cultured. Also, it has been observed that $23 \%$ of yeast genes have homology to human genes (Liu et al., 2017). This conservation between human and yeast genes makes yeast an ideal organism for study of human conditions.

Chemical genetic analysis identifies a chemical genetic interaction, whereby a chemical probe (a bioactive compound) results in the growth defect of a gene deletion mutant compared to growth in the absence of the chemical probe. Further, a gene deletion collection can be utilized for elucidation of compound mechanism of action by subjecting it to the chemical probe. A chemical genetic profile can be created from gene deletion mutants exhibiting a growth defect or sensitivity as a result of exposure to the chemical perturbation to predict mode of action for a compound/extract (Boone et al., 2007). Further, when an array of mutants is 
challenged with a compound and monitored for fitness defects, chemical-genetic interaction profile can be generated that provides a quantitative, unbiased description of the cellular function(s) perturbed by the compound (Simpkins et al., 2018).

\subsection{Aim}

Since little is known about the chemistry and biology mediating the traditional use of A. amatymbica, this thesis aims to characterise the chemical biology of the A. amatymbica extract to further understand its traditional use. The specific aims are the following: Aim 1: To identify the most potent bioactive compound in the A. amatymbica extract. Aim 2: To determine the potential mechanism of action of the A. amatymbica extract using chemical genetic analysis in yeast. 


\section{Chapter 2:}

\subsection{Introduction}

The A. amatymbica extract was prepared by Drs Edwina Muleya and Joe Bracegirdle and Robert Keyzers in a collaboration between Victoria University of Wellington and Midlands State University in Zimbabwe. Here we use chemical genetics to investigate the genes, and pathways underlying the molecular mechanism of the extract. The use of gene deletions, gene overexpressions and GFP-tagged proteins allows us to investigate mechanism of action at the gene and protein level. The yeast deletion collection consists of $\sim 4,300$ strains each having a different gene deletion was used to identify genes required to buffer the bioactivity of the extract. A GFP library consisting of $\sim 400$ strains each having a uniquely tagged protein, was used to identify proteins that altered in response to the addition of the extract. Together, these were used to deduce the mechanism of action of the extract. 


\subsection{Materials and methods}

\subsubsection{Yeast strains}

All S. cerevisiae strains were derived from the wild-type (WT) Y7092 strain (Table 2.1)

\begin{tabular}{|c|c|c|}
\hline Strain & Genotype & Reference \\
\hline Y7092 & 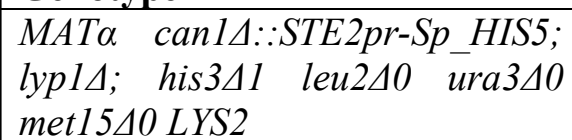 & (Tong \& Boone, 2007) \\
\hline $\begin{array}{l}\text { pdr1 } 1 p d r 3 \Delta \\
\text { (Y7092 derived) }\end{array}$ & 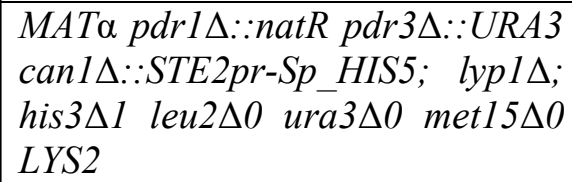 & (Coorey et al., 2015) \\
\hline $\begin{array}{l}\text { pdr1 } 4 p d r 34 \\
\text { collection (Y7092 derived) }\end{array}$ & 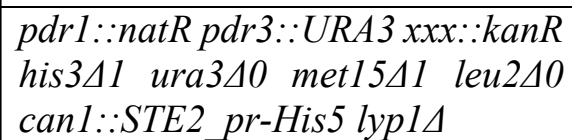 & (Coorey et al., 2015) \\
\hline BY4741 & 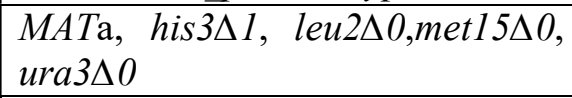 & $\begin{array}{l}\text { (Baker Brachmann et } \\
\text { al., 1998) }\end{array}$ \\
\hline SWAT-NOP1pr-GFP & 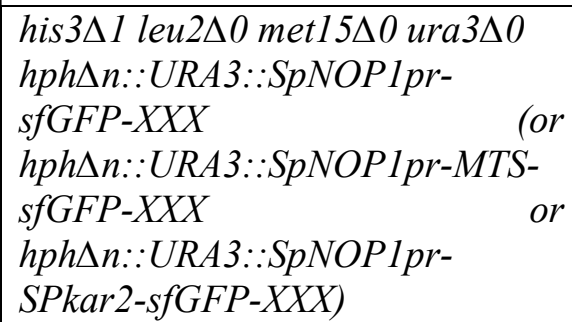 & (Ast et al., 2013) \\
\hline
\end{tabular}

Table 2.1: Yeast strains used in this thesis.

\subsubsection{Media}

\section{Amino acid composition for Synthetic complete (SC) media:}

$3 \mathrm{~g}$ adenine, $2 \mathrm{~g}$ alanine, $2 \mathrm{~g}$ asparagine, $2 \mathrm{~g}$ aspartic acid, $2 \mathrm{~g}$ cysteine, $2 \mathrm{~g}$ glutamic acid, $2 \mathrm{~g}$ glutamine, $2 \mathrm{~g}$ glycine, $2 \mathrm{~g}$ histidine, $2 \mathrm{~g}$ inositol, $2 \mathrm{~g}$ isoleucine, $10 \mathrm{~g}$ leucine, $2 \mathrm{~g}$ lysine, $2 \mathrm{~g}$ methionine, $0.2 \mathrm{~g}$ para-aminobenzoic acid, $2 \mathrm{~g}$ phenylalanine, $2 \mathrm{~g}$ proline, $2 \mathrm{~g}$ serine, $2 \mathrm{~g}$ threonine, $2 \mathrm{~g}$ tryptophan, $2 \mathrm{~g}$ tyrosine, $2 \mathrm{~g}$ uracil and $2 \mathrm{~g}$ valine.

\section{SC agar media composition:}

$0.1 \%(\mathrm{w} / \mathrm{v})$ monosodium glutamate, without acids or ammonium sulphate (Sigma-Aldrich), $0.17 \%(\mathrm{w} / \mathrm{v})$ Yeast Nitrogen Base (Formedium), 0.2\% (w/v) amino acid mixture to suit 
(Formedium), 2\% (w/v) glucose (Sigma-Aldrich) and 2\%(w/v) granulated bacteriological grade agar (Formedium).

\section{Synthetic dropout (SD) agar:}

SC agar with the absence of specific amino acid(s).

\section{Synthetic dropout (SD) broth:}

SC broth with the absence of specific amino acid(s).

\section{Complete Minimum (CM) media composition:}

$0.2 \%(\mathrm{w} / \mathrm{v})$ amino acid mixture (Sigma-Life Sciences) at pH 5.8 and 2\% (w/v) glucose (SigmaAldrich).

\section{CM agar media composition:}

$0.2 \%(\mathrm{w} / \mathrm{v})$ amino acid mixture (Sigma-Life Sciences) at $\mathrm{pH} 5.8,2 \%(\mathrm{w} / \mathrm{v})$ glucose (SigmaAldrich) and 2\% (w/v) granulated bacteriological grade agar (Formedium).

\section{Yeast peptone dextrose (YPD) media composition:}

$2 \%(\mathrm{w} / \mathrm{v})$ yeast extract (Formedium), 2\% (w/v) peptone (Formedium), 0.012\% (w/v) adenine (Formedium) and 2\% glucose (Sigma-Aldrich).

\section{YPD agar media composition:}

2\% (w/v) yeast extract (Formedium), 2\% (w/v) peptone (Formedium), 0.012\% (w/v) adenine (Formedium), 2\% (w/v) agar granulated bacteriological grade (Formedium) and 2\% glucose (Sigma-Aldrich).

\section{LB agar:}

$0.5 \%(\mathrm{w} / \mathrm{v})$ yeast extract (Formedium), $1 \%(\mathrm{w} / \mathrm{v})$ tryptone (Formedium), $0.5 \%(\mathrm{w} / \mathrm{v})$ sodium chloride (Thermo Fisher Scientific) and 2\% (w/v) agar granulated bacteriological grade (Formedium). 


\section{LB broth:}

$0.5 \%(\mathrm{w} / \mathrm{v})$ yeast extract (Formedium), $1 \%(\mathrm{w} / \mathrm{v})$ tryptone (Formedium) and $0.5 \%(\mathrm{w} / \mathrm{v})$ sodium chloride (Thermo Fisher Scientific).

\subsubsection{Compound preparation}

The A. amatymbica extract and all semi-purified compounds (including compound B) were prepared by Drs. Edwina Muleya, Joe Bracegirdle and Rob Keyzers at Victoria University of Wellington. The extracts and compounds were dissolved in DMSO.

\subsubsection{Liquid-based bioactivity assays}

Bioactivity was assessed by quantifying the growth of yeast as described previously (Treco \& Winston, 2008). Yeast strains were freshly streaked from frozen stocks onto YPD agar and incubated at $30^{\circ} \mathrm{C}$ for $48 \mathrm{~h}$. A single colony was inoculated into $2 \mathrm{~mL}$ of relevant media and incubated at $30^{\circ} \mathrm{C}$ for $16-18 \mathrm{~h}$ with constant rotation. Optical density (OD) of the overnight culture was measured at $660 \mathrm{~nm}$ using a spectrophotometer (Jenway Genova MK3), and then diluted in $1 \mathrm{~mL}$ of relevant media to give a final OD of 0.1 . In a 96-well tissue culture plate (Biofill), $99 \mu \mathrm{L}$ of CM media containing the yeast cells was added, followed by $1 \mu \mathrm{L}$ of either the A. amatymbica extract, a semi purified compound or DMSO vehicle control in triplicates. The plates were shaken on a MixMate plate shaker (Eppendorf) for $30 \mathrm{sec}$ at 1,000 rpm. An initial absorbance reading was taken at time zero (T0) using an Envision 2102 Multilabel plate reader (Perkin Elmer) at $590 \mathrm{~nm}$. The plates were then incubated at $30^{\circ} \mathrm{C}$, and OD readings were later taken after $18 \mathrm{~h}$ and every hour thereafter until OD 0.4 (mid-log phase) was reached in the control wells. OD readings were normalized by subtracting the T0 OD readings from each time point. Residual growth of the yeast was calculated based on the growth 
of the cells in the treated wells in comparison to untreated wells. A two-tailed student t-test was performed to assess significant differences in growth.

\subsubsection{Agar-based bioactivity assays}

Growth in agar was quantified as previously described (Wagih et al., 2013). In 24-well tissue culture plates (Biofill), $1 \mu \mathrm{L}$ of extract or compound B was mixed with $1 \mathrm{~mL}$ of molten agar $\left(\sim 60^{\circ} \mathrm{C}\right)$ via gentle pipetting. The plates were left to set at room temperature for $1 \mathrm{~h}$. Cells of overnight cultures were then diluted to three different concentrations $\left(1 \times 10^{7}\right.$ cells $/ \mathrm{mL}, 1 \mathrm{x}$ $10^{5}$ cells $/ \mathrm{mL}$ and $1 \times 10^{3}$ cells $/ \mathrm{mL}$ ), and $2 \mu \mathrm{L}$ of each concentration was spotted onto each well. The plates were left to dry for approximately 1 hour before incubation at $30^{\circ} \mathrm{C}$. Photographs were taken at $24 \mathrm{~h}$ and $48 \mathrm{~h}$ using a digital camera (Canon EOS 600D) and differences in growth were based on visual observation.

\subsubsection{Genome-wide analysis}

Sensitivity of gene deletion strains in a genome-wide library was measured as previously described (Parsons et al., 2006) . The 4,300 strains in the homozygous haploid deletion library were replicated using an automated replicator (Singer Rotor, HDA) onto 40 $\mathrm{mL}$ of CM agar with A. amatymbica extract or DMSO vehicle control. Plates were incubated at $30^{\circ} \mathrm{C}$ for $24 \mathrm{~h}$, photographs were taken using a digital camera (Canon EOS 600D), and growth was quantified using SGA tools (Wagih et al., 2013). All deletion mutants with Z-score

greater than 1 or less than -1 were chosen for validations using liquid growth assays as previously described. 


\subsubsection{Genomic DNA extraction}

Genomic DNA extractions were performed as described previously (Sobanski \& Dickinson, 1995). First, $1 \mathrm{~mL}$ of overnight grown yeast culture was centrifuged in a $1.5 \mathrm{~mL}$ tube. Then $200 \mu \mathrm{L}$ of DNA breaking buffer and $100 \mu \mathrm{L}$ of beads were added onto the pellets, followed by the addition of $200 \mu \mathrm{L}$ of phenol:chloroform:isoamyl alcohol (25:24:1), and the tubes were vortexed for $5 \mathrm{~min}$, and centrifuged for $5 \mathrm{~min}$. The aqueous phase was added to a tube with $1 \mathrm{~mL} \mathrm{95 \%} \mathrm{ethanol} \mathrm{and} \mathrm{then} \mathrm{centrifuged} \mathrm{for} 5 \mathrm{~min}$ before the supernatant was discarded and the pellets were dried, resuspended in $40 \mu \mathrm{L} \mathrm{TE}$, and stored in $-20^{\circ} \mathrm{C}$.

\subsubsection{Proteome-wide analysis}

Using a green fluorescent protein (GFP) library of S. cerevisiae strains (Weill et al., 2018), localization of 320 proteins in response to the A. amatymbica extract was monitored using confocal fluorescent microscopy. The 320 strains were pinned in 384 colony format on $\mathrm{SC}$ agar, grown for $16 \mathrm{~h}$ at $30^{\circ} \mathrm{C}$, and then pinned into a Cell Carrier optically clear bottom 384 well plate (Perkin Elmer) treated with $0.003 \% \mathrm{SDS}$, and incubated at $30^{\circ} \mathrm{C}$ for $4 \mathrm{~h}$. The plates were then treated with either vehicle control $(0.5 \% \mathrm{DMSO})$ or three extract treatments (15 $\mu \mathrm{g} / \mathrm{mL}, 20 \mu \mathrm{g} / \mathrm{mL}$ or $25 \mu \mathrm{g} / \mathrm{mL}$ ), shaken for $15 \mathrm{sec}$ at 2,000 rpm with a MixMate plate shaker (Eppendorf), and incubated at $30^{\circ} \mathrm{C}$ for $2 \mathrm{~h}$. GFP fluorescence was imaged using an IN Cell Analyzer 7.3, 6500 HS high-throughput confocal microscope (General Electric), with the following specifications: Objective: Nikon 60X/0.95, Imaging mode: 2D, green excitation: 488 nm, emission: $524 \mathrm{~nm}$, exposure: $1000 \mathrm{~ms}$, laser Power: 100\%, brightfield: default values using, DIC filter, and images analysed by eye (specifically two independent persons). 


\subsubsection{PCR amplification:}

All PCRs were performed using BIO RAD T100 ${ }^{\mathrm{TM}}$ Thermal Cycler (Bio-Rad Laboratories) with reagents and volume given in Table 2.2. The reaction conditions are given in Table 2.4 and Table 2.5. Specifically $5 \mu \mathrm{L}$ of PCR products were electrophoresed on a $1 \%$ agarose gel stained with ethidium bromide and visualised under UV to ensure the PCR products were of the correct size when compared to $1 \mathrm{~kb}$ Plus DNA Ladder (Thermo Scientific ${ }^{\mathrm{TM}}$ ).

\begin{tabular}{|l|l|}
\hline Reagent & Reaction volume $(\boldsymbol{\mu L})$ \\
\hline $\mathrm{H}_{2} 0$ & 18.875 \\
\hline $10 \mathrm{X}$ Buffer & 2.5 \\
\hline dNTPs & 2 \\
\hline $\begin{array}{l}\text { Deletion primer (Forward) or confirmation } \\
\text { primer forward external }\end{array}$ & 0.5 \\
\hline $\begin{array}{l}\text { Deletion primer (Reverse) or confirmation } \\
\text { primer reverse external }\end{array}$ & 0.5 \\
\hline rTaq & 0.125 \\
\hline Plasmid DNA & 0.5 \\
\hline
\end{tabular}

Table 2.2: PCR reagents and reaction volumes

\subsubsection{Construction of deletion cassette}

The LEU2 deletion cassette was constructed by amplifying the gene from $p U G 73$ plasmid with deletion primers listed in Table 2.3. Each 68 base pair deletion primer consists of an 18 bp region with homology to the 5' or 3' ends of the LEU2 cassette and the remaining 50 bp region with homology to the 5' or 3' flanking genomic regions of the GET2 or GET2 locus. The GET1 and GET2 locus were replaced by LEU2 cassette by homologous recombination resulting in get $1:: L E U 2$ and get $2:$ LEU2 mutants (Fig. 2.1). The LEU2 gene in the mutants permits selection in media lacking the amino acid leucine. 


\begin{tabular}{|l|l|}
\hline \multirow{2}{*}{ Primer } & Sequence 5' to 3' \\
\hline \multirow{2}{*}{ forward deletion primer } & TTGCAATCCTTGAACTACGTCTAGTTGATTGA \\
\cline { 2 - 2 } GET1 deletion primer & AATAGGAGAAATGAGCTGAAGCTTCGTACGC \\
\cline { 2 - 2 } reverse & TGTAATAACACTACATAGGCCACTAGTGGATCTG \\
\hline \multirow{2}{*}{ fET2 deletion primer } & AGCGCAGATTACTAAGAGAAAGGAGACAGAAGAAGT \\
\cline { 2 - 2 } forwatA & TTAGCAATGAGCTGATGAAGCTTCGTACGC \\
\hline \multirow{2}{*}{ reverse deletion primer } & TCAGGTTGGCGACGGGAATTACTCCCTCGGGCACCAGTG \\
\cline { 2 - 2 } & AAACTACATAGGCCACTAGTGGATCTG \\
\hline
\end{tabular}

Table 2.3: Deletion PCR primers. The deletion primers were designed with 50 bp of homology to the 5' or 3' flanking regions of Get 1 or Get2 loci and 18 bp with homology to Leu2 cassette.

\begin{tabular}{|l|l|l|l|}
\hline PCR phase & Temperature $\left({ }^{\mathbf{0}} \mathbf{C}\right)$ & Time & Number of cycles \\
\hline Initial denaturation & $94^{0} \mathrm{C}$ & 5 minutes & 1 \\
\hline Denaturation & $94{ }^{0} \mathrm{C}$ & 30 seconds & 36 \\
\hline Annealing & $58{ }^{0} \mathrm{C}$ & 1 minute & 36 \\
\hline Extension & $68{ }^{0} \mathrm{C}$ & 3 minutes & 36 \\
\hline Final extension & $72{ }^{0} \mathrm{C}$ & 10 minutes & 1 \\
\hline
\end{tabular}

Table 2.4: PCR conditions for the deletion of GET1 and GET2 
(A)

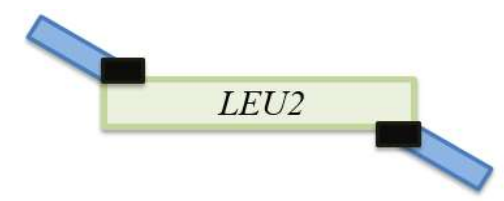

(B)

(C)

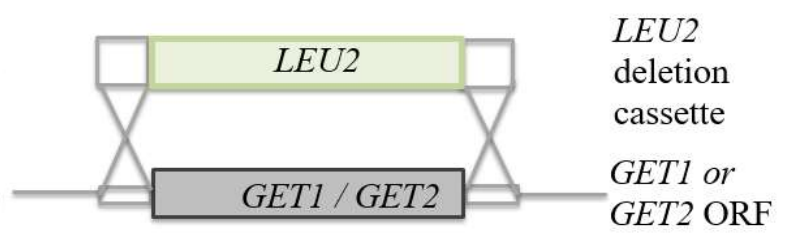

(D)

LEU2
LEU2 cassette and deletion primers

LEU2

deletion

cassette

GET2 ORF

get $1 \triangle:: L E U 2$ or

get $2 \Delta:: L E U 2$

1Figure 2.1 : Construction of get $1:: L E U 2$ and get $2:$ LEU2. (A) Blue bar represents $50 \mathrm{bp}$ sequence of the deletion primer homologous to the 5' or 3' flanking region of the GET1 or GET2 locus. Black bar represents 18 bp sequence of the deletion primer homologous to the LEU2 cassette. (B) LEU2 deletion cassette from the PCR reaction using the deletion primers and $L E U 2$ cassette. (B-C) Schematic diagram of recombination event between $L E U 2$ gene deletion cassette and GET1 or GET2 locus leading to (D) get $1:$ LEU2 or get $2:: L E U 2$ mutant.

\subsubsection{Construct confirmation by PCR}

Genomic DNA was harvested from a single colony of get $1:$ LEU2 and get $2: \because L E U 2$, and 5' and 3' genomic flanking regions of the deletion cassette were amplified using PCRbased strategy illustrated in Fig. 2.2. Confirmation primers are listed in Table 2.5 and PCR conditions given in Table 2.6. 


\begin{tabular}{|c|c|}
\hline Primer & Sequence (5' to 3') \\
\hline $\begin{array}{l}\text { Confirmation primer } \\
\text { reverse external } \\
\text { get } 1:: L E U 2\end{array}$ & CACCAATTTACAGATTCGGATTAAC \\
\hline $\begin{array}{lr}\text { Confirmation } & \text { primer } \\
\text { forward } & \text { external } \\
\text { get } 1: \text { :LEU2 } & \end{array}$ & TTACTAAAGTTTGGTGACAGGAAGC \\
\hline $\begin{array}{lr}\text { Confirmation } & \text { primer } \\
\text { reverse } & \text { external } \\
\text { get } 2:: L E U 2 & \\
\end{array}$ & GAGCATTACTCTCTTTGTGAAAAGG \\
\hline $\begin{array}{lr}\text { Confirmation } & \text { primer } \\
\text { forward } & \text { external } \\
\text { get } 2:: L E U 2 & \end{array}$ & TATACATCGATTTTTCACGAACTCA \\
\hline
\end{tabular}

Table 2.5: Confirmation PCR primers. All primers were constructed according to a few references (Baudin et al., 1993; Wach et al., 1994).

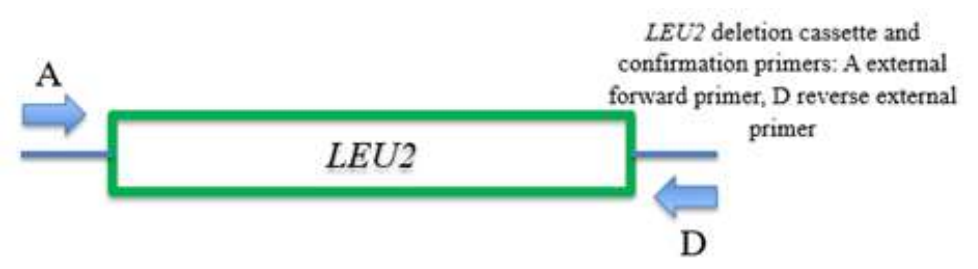

Figure 2.2: Construction of confirmation primers. Strategy used to confirm the correct insertion of $L E U 2$ deletion cassettes into respective GET1 and GET2 loci. 25 bp confirmation primers were used to amplify sequences overlapping the 5' and 3' flanking regions of the deletion cassettes. Direction of the arrows designates the direction of primer extension. Primers denoted as A external forward primer and D reverse external primer (sequences given in Table 2.5). 


\begin{tabular}{|l|l|l|l|}
\hline PCR phase & Temperature $\left({ }^{\mathbf{0}} \mathbf{C}\right)$ & Time & Number of cycles \\
\hline Initial denaturation & $92^{0} \mathrm{C}$ & 5 minutes & 1 \\
\hline Denaturation & $94{ }^{0} \mathrm{C}$ & 30 seconds & 36 \\
\hline Annealing & $58{ }^{0} \mathrm{C}$ & 30 seconds & 36 \\
\hline Extension & $72{ }^{0} \mathrm{C}$ & 3 minutes 30 seconds & 36 \\
\hline Final extension & $72{ }^{\circ} \mathrm{C}$ & 10 minutes & 1 \\
\hline
\end{tabular}

Table 2.6: PCR conditions for the confirmation of get1::LEU2 and get2::LEU2

\subsubsection{Yeast transformation}

All transformations were performed as previously described (Gietz \& Schiestl, 2007)

(Table 2.7). Overnight cultures of get $1 \Delta$ and get $2 \Delta$ was sub-cultured in YPD broth to obtain an $\mathrm{OD}$ of 0.2 , and the culture was grown with shaking at $250 \mathrm{rpm}$ at $30^{\circ} \mathrm{C}$ until cells were harvested when an OD of 0.8 was achieved. Cells were first washed with $25 \mathrm{~mL}$ of dd $\mathrm{H}_{2} \mathrm{O}$ and then $10 \mathrm{~mL}$ of $1 \mathrm{M} \mathrm{LiOAc-TE}$, and then resuspended in $1 \mathrm{~mL}$ of LiOAc-TE. $360 \mu \mathrm{L}$ of the transformation mixture was added to $100 \mu \mathrm{L}$ of cells, with $4 \mu \mathrm{L}$ of pBY011 plasmid or water control. Cells were then heat-shocked at $42^{\circ} \mathrm{C}$ for $40 \mathrm{~min}$, harvested by centrifugation, and resuspended in $1 \mathrm{~mL}$ water, of which $300 \mu \mathrm{L}$ was then plated onto SD-Ura agar using a cell spreader and incubated at $30^{\circ} \mathrm{C}$ for two days.

\begin{tabular}{|l|l|}
\hline Transformation mixture components & Volume $(\mu \mathrm{L})$ \\
\hline PEG $50 \% \mathrm{w} / \mathrm{v}$ & 240 \\
\hline LiAc & 36 \\
\hline SS-carrier DNA & 50 \\
\hline Plasmid DNA & 4 \\
\hline $\mathrm{H}_{2} \mathrm{O}$ & 30 \\
\hline Total volume & 360 \\
\hline
\end{tabular}

Table 2.7: Components of transformation mixture.

\subsubsection{Bacterial plasmid DNA extraction}

The overexpression bacterial plasmid in the pBY011 vector was extracted from Escherichia coli (Birnboim \& Doly, 1979). E. coli was streaked onto LB+ampicillin agar and incubated at $37^{\circ} \mathrm{C}$ for $24 \mathrm{~h}$. A single colony was transferred into $2 \mathrm{~mL}$ LB+ampicillin and 
incubated for $24 \mathrm{~h}$ at $37^{\circ} \mathrm{C}$ with vigorous shaking. The culture was centrifuged, pellets were dried and, resuspended in $100 \mu \mathrm{L}$ ice-cold solution I, then in $200 \mu \mathrm{L}$ of freshly prepared icecold Solution II, followed by $150 \mu \mathrm{L}$ of ice-cold solution III. The mixture was centrifuged, the supernatant precipitated in absolute alcohol, allowed to stand at $4^{\circ} \mathrm{C}$ for $5 \mathrm{~min}$, then centrifuged, and the supernatant was removed, pellets rinsed in $70 \%$ ethanol, centrifuged, air dried, resuspended in $1 \mathrm{x}$ TE and stored in $-20^{\circ} \mathrm{C}$. Solutions I, II and III were prepared as previously described (Birnboim \& Doly, 1979) (Table 2.8).

\begin{tabular}{|l|l|l|}
\hline Solution I & Solution II & Solution III \\
\hline $1 \mathrm{M}$ Glucose $-5 \mathrm{~mL}$ & $0.4 \mathrm{M}$ Sodium & $5 \mathrm{M} \mathrm{Potassium}$ \\
$1 \mathrm{M}$ Tris-Cl $(\mathrm{pH} 8.0)-25 \mathrm{~mL}$ & hydroxide $-1 \mathrm{~mL}$ & acetate- $60 \mathrm{~mL}$ \\
$0.5 \mathrm{M}$ EDTA $(\mathrm{pH} 8.0)-2 \mathrm{~mL}$ & $2 \%$ SDS- $1 \mathrm{~mL}$ & Glacial acetic acid - \\
$\mathrm{ddH}_{2} \mathrm{O}-68 \mathrm{~mL}$ & & $11.5 \mathrm{~mL}$ \\
& & $\mathrm{ddH}_{2} \mathrm{O}-28.5 \mathrm{~mL}$ \\
\hline
\end{tabular}

Table 2.8: Solutions for bacterial plasmid DNA extraction.

\subsubsection{Overexpression assay}

Overexpression of genes under the regulation of a galactose promoter was investigated as previously described (Reynolds et al., 1997). pdr1 $\operatorname{pdr} 3 \Delta e t 1 \Delta$ and $p d r 1 \Delta p d r 3 \Delta$ get $2 \Delta$ transformed with pBY011 overexpression plasmid were grown overnight at $30^{\circ} \mathrm{C}$ in synthetic drop out media in $2 \%$ raffinose, and then: (1) plated on agar containing $2 \%$ glucose (repression) or $2 \%$ galactose (overexpression) with appropriate concentrations of $A$. amatymbica extract or compound $\mathrm{B}$, incubated at $30^{\circ} \mathrm{C}$ for $24 \mathrm{~h}$, and imaged using a digital camera (Canon EOS 600D); (2) grown in SD-URA and $2 \%$ galactose (overexpression) in the presence of $A$. amatymbica. 


\subsubsection{Dose response of compound B and semi-purified compounds}

Bioactivity of semi-purified fractions was measured on agar or in liquid as previously described (2.2.4 and 2.2.5).

\subsubsection{Gene annotation}

Genes found to be sensitive to A. amatymbica were analysed using online tools to better understand the mechanism of action of the extract. Spatial Analysis of Functional Enrichment (SAFE) (https://thecellmap.org/) was used to determine processes and pathways critical within those sensitive gene set (Usaj et al., 2017). The YEASTRACT+ information system (http://www.yeastract.com/ ) was used to predict transcription regulators associated with the sensitive input gene set (Monteiro et al., 2019). GENEONTOLOGY (http://geneontology.org/) was used to map the gene ontology (GO) categories that were statistically over represented within the sensitive input genes (Ashburner et al., 2000). 


\subsection{Results}

\subsubsection{The $A$. amatymbica extract is a PDR substrate}

The pleiotropic drug resistance (PDR) network in yeast is comprised of drug efflux transporters encoded by the ATP binding cassette (ABC) and major facilitator superfamily (MFS) genes (Kolaczkowska \& Goffeau, 1999). The system functions to remove xenobiotics from the cells, leading to less compound accumulating in the cell (DeRisi et al., 2000). The ABC transporters are controlled by the transcription factors Pdr1 and Pdr3. Hence, in PDRattenuated yeast strains lacking the $\mathrm{Pdr} 1$ and $\mathrm{Pdr} 3$, the expression of $\mathrm{ABC}$ transporters is reduced leading to greater drug sensitivity (Coorey et al., 2015).

To determine if the A. amatymbica extract was a substrate of the PDR network, the growth of the PDR-attenuated strain $p d r 1 \Delta p d r 3 \Delta$ was compared to wild type (BY4741) in the presence and absence of the extract (Fig. 2.3). The cells were inoculated in SC media treated with the extract in triplicates at concentrations ranging from $2.4 \times 10^{-3} \mu \mathrm{g} / \mathrm{mL}$ to $10 \mu \mathrm{g} / \mathrm{mL}$. A vehicle control (DMSO) was included as a baseline for normal growth. Growth was measured based on absorbance and residual growth was calculated as the mean percentage of growth in the treated compared to the untreated controls. Based on $40 \%$ growth inhibition ( $60 \%$ residual growth) as a cut-off for bioactivity in $p d r 1 \Delta p d r 3 \Delta$ the extract exhibited bioactivity at 2.5 $\mu \mathrm{g} / \mathrm{mL}$ while in WT bioactivity was observed at $10 \mu \mathrm{g} / \mathrm{mL}$. Overall, the extract was bioactive in both WT and $p d r 1 \Delta p d r 3 \Delta$, with more potency observed in $p d r 1 \Delta p d r 3 \Delta$. Based on this growth defect, the extract is a likely substrate of the PDR drug efflux pumps. Hence further experiments were conducted using the $p d r 1 \Delta p d r 3 \Delta$ background. 


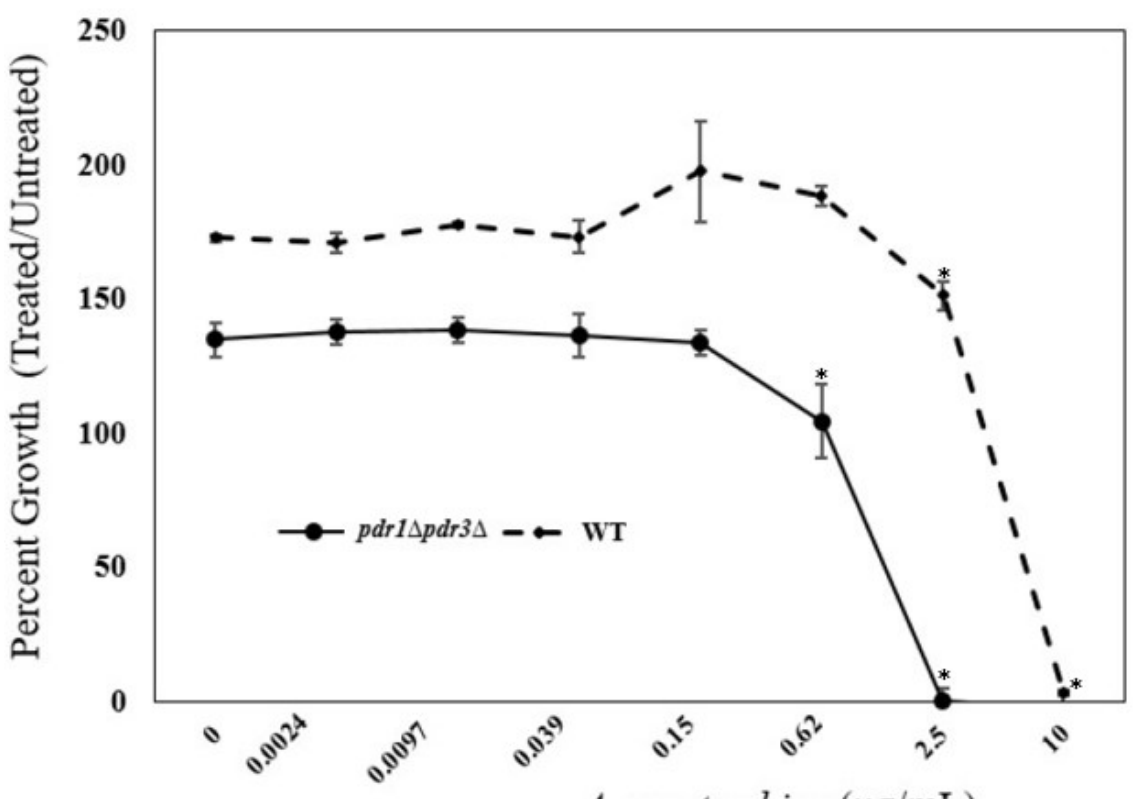

A. amatymbica $(\mu \mathrm{g} / \mathrm{mL})$

Figure 2.3: Liquid-based assay of WT (BY4741) and $p r d 1 \Delta p d r 3 \Delta$ grown in A. amatymbica extract. Cells were inoculated in SC media treated with increasing concentrations of extract. The growth was measured based on $\mathrm{OD}_{590}$ absorbance in treated compared to vehicle control cells. Error bars represent mean \pm SD. ${ }^{*}, \mathrm{p} \leq 0.05$, student t- test relative to control.

\subsubsection{The $A$. amatymbica extract was more bioactive in CM media}

To determine in which liquid media the A. amatymbica extract was most bioactive, the growth of $p d r 1 \Delta p d r 3 \Delta$ was evaluated in SC media and CM media (Fig. 2.4). The CM media has fewer nutrients compared to SC media, and ensures that the physiological condition is buffered at $\mathrm{pH} 5.8$, since bioactivity can be influenced by many factors. The residual growth of $p d r 1 \Delta p d r 3 \Delta$ inoculated in either $\mathrm{SC}$ or $\mathrm{CM}$ was calculated at various concentrations of extract. Bioactivity in $\mathrm{CM}$ was observed at $0.44 \mu \mathrm{g} / \mathrm{mL}$ of extract with $\sim 60 \%$ residual growth, while bioactivity in SC media was observed around 10 times that concentration at $4 \mu \mathrm{g} / \mathrm{mL}$ 
(Fig.2.4). These results indicate that the extract was more bioactive in CM media, thus further experiments were conducted in CM media.

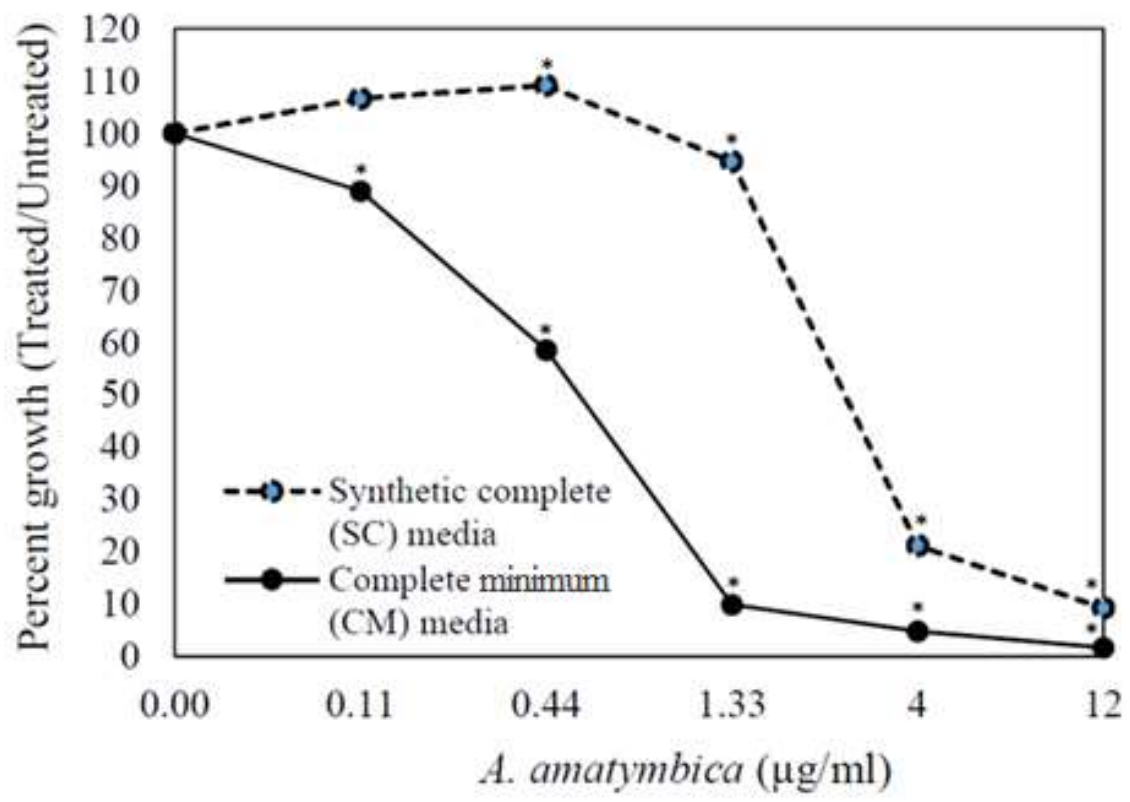

Figure 2.4: Liquid-based bioactivity assay of $p d r 1 \Delta p d r 3 \Delta$ yeast strain in different media.

Cells were inoculated in SC or CM media treated with increasing concentrations of the $A$. amatymbica extract. The growth was measured based on $\mathrm{OD}_{590}$ absorbance in treated compared to vehicle control cells (DMSO). Error bars represent mean \pm SD. $* p \leq 0.05$, student t- test relative to control.

\subsubsection{Compound B is potent in liquid media}

To determine which of the compounds in the A. amatymbica extract were bioactive, the growth of $p d r 1 \Delta p d r 3 \Delta$ in CM media was evaluated in the presence of five different semipurified fractions generated by chemistry student Joe Bracegirdle (Fig. 2.5). These compounds were used here at concentrations ranging from $0.004 \mu \mathrm{g} / \mathrm{mL}$ to $10 \mu \mathrm{g} / \mathrm{mL}$. Relative to the $0.5 \%$ DMSO vehicle control, growth in fraction-treated cells was measured at mid-log growth phase. 
Based on the criterion of $40 \%$ growth inhibition for bioactivity, compound B was potently bioactive at $3.33 \mu \mathrm{g} / \mathrm{mL}$ and $10 \mu \mathrm{g} / \mathrm{mL}$ where these concentrations were nearly lethal. In contrast, compounds $\mathrm{C}, \mathrm{E}, \mathrm{F}$ and $\mathrm{G}$ were not bioactive at any concentration. Hence, compound $\mathrm{B}$ is the most potent of the semi-purified compounds, suggesting a role of compound B in the bioactivity of the A. amatymbica extract.

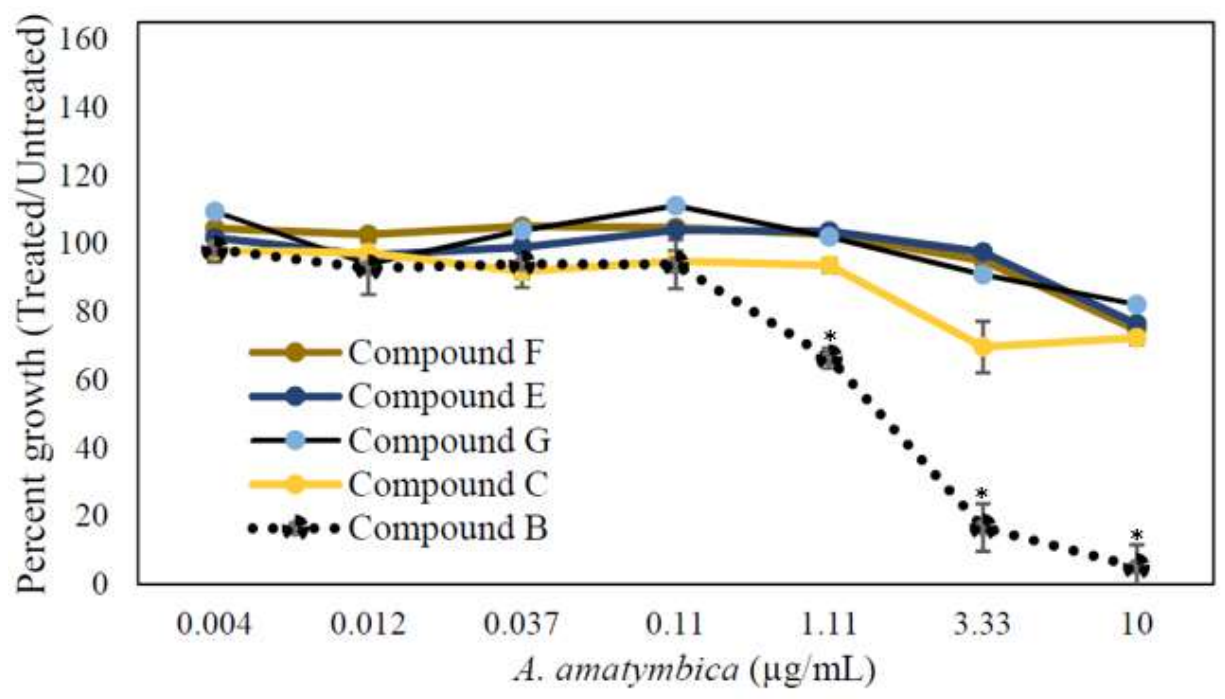

Figure 2.5: Liquid-based bioactivity assay of $p d r 1 \Delta p d r 3 \Delta$ in response to different semipurified fractions derived from the A. amatymbica extract. Liquid-based bioactivity assay of $p d r 1 \Delta p d r 3 \Delta$ yeast strain in different media. Cells were inoculated in CM media treated with increasing concentrations of the semi-purified fractions. The growth was measured based on $\mathrm{OD}_{590}$ absorbance in treated compared to vehicle control cells. Error bars represent mean \pm SD. ${ }^{*}, \mathrm{p} \leq 0.05$, student $\mathrm{t}$ test relative to control.

\subsubsection{The extract and compound $B$ are bioactive in agar}

Genome-wide analyses using mutant libraries of yeast have been used to successfully identify mechanism of action of extracts and compounds in agar (Giaever et al., 2004; Parsons et al., 2006). Compounds that are bioactive in liquid media may not be bioactive in agar, or 
alternatively, these compounds may be less potent in agar. Therefore, to determine the bioactivity of the A. amatymbica extract and compound B in agar, growth of serial dilutions of pdr1 $1 \Delta p d r 3 \Delta$ was evaluated on $\mathrm{CM}$ agar treated with the extract and compound $\mathrm{B}$ at concentrations ranging from 0.375 to $6 \mathrm{mg} / \mathrm{mL}$ (Fig. 2.6). Relative to control, the crude extract and compound B were both bioactive with very little growth at $6 \mathrm{mg} / \mathrm{mL}$. At 1.5 and $3 \mathrm{mg} / \mathrm{mL}$, the growth in extract-treated cells was comparable to control while there was very little growth in compound B-treated cells compared to control. These results established that the $A$. amatymbica extract and compound B were both bioactive in agar, albeit with the latter being more potent than the former.

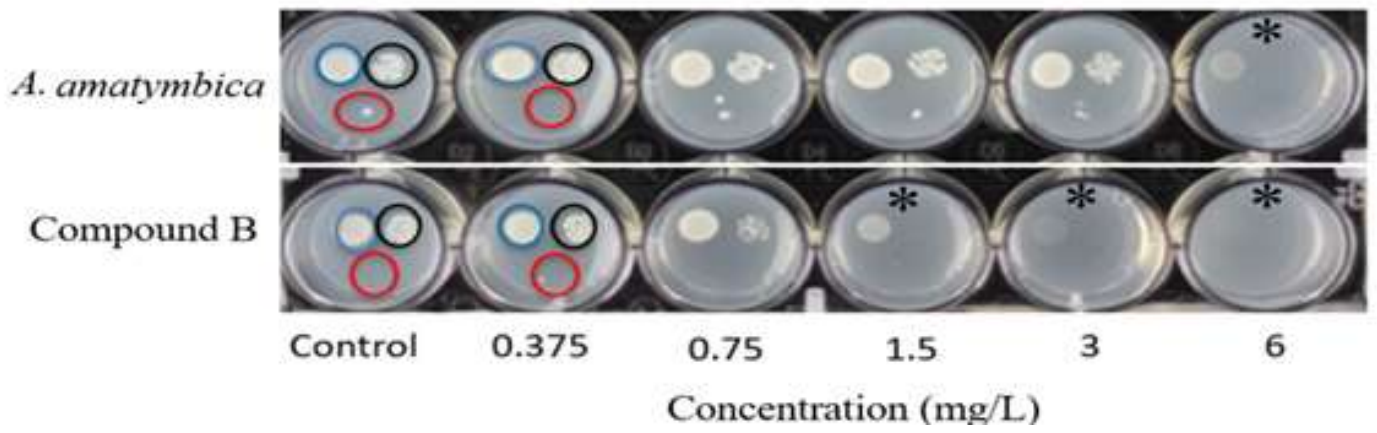

Figure 2.6: Agar-based dose response assay of the A. amatymbica extract and semi-purified compound B. Serial dilutions ( $1 \times 10^{3}$ (red), $1 \times 10^{5}$ (blue) or $1 \times 10^{7}$ cells $/ \mathrm{mL}$ (Fischli et al.)) of $p d r 1 \Delta p d r 3 \Delta$ were spotted on agar treated with varying concentrations of extract or semipurified compound, incubated for 24 hours and imaged using a digital camera. *, Visibly distinct growth inhibition.

\subsubsection{Optimisation of $A$. amatymbica extract for genome-wide analysis in agar}

To conduct a viability-based genome-wide analysis of the gene deletion library in the pdr1 $1 p d r 3 \Delta$ background, a concentration was first identified that yielded $10-20 \%$ growth inhibition in the $p d r 1 \Delta 3 \Delta$ strain in the same format used in the genome-wide analysis. This 
concentration ensures there is a large window (80-90\%) to detect additional growth inhibition due to the gene deletion. Using a representative library plate in 1,536 colony format, growth was quantified using SGA tools (Wagih et al., 2013). At $38 \mu \mathrm{g} / \mathrm{mL}$ of the aqueous extract, approximately $20 \%$ of growth was inhibited across all 1,536 colonies in the entire treated plate compared to the vehicle control (Fig. 2.7). Unfortunately, there was not enough compound B to conduct a genome-wide analysis.

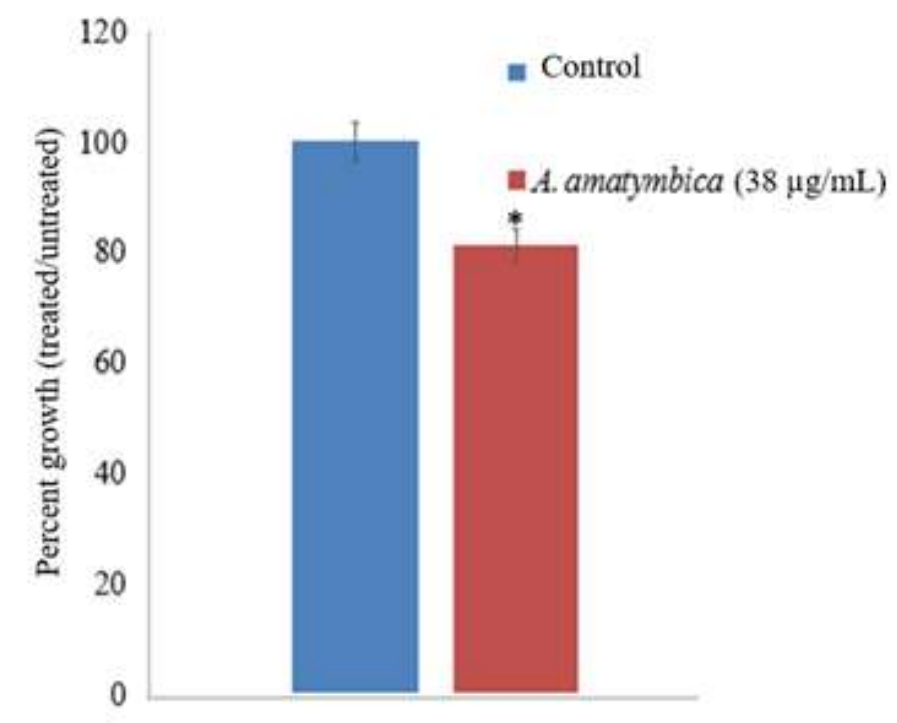

Figure 2.7: Optimisation of $A$. amatymbica extract treatment for genome-wide analysis of gene deletion library. A random plate from the gene deletion library (comprised of 1,536 colonies) was grown on agar containing $38 \mu \mathrm{g} / \mathrm{mL}$ of extract or vehicle control, incubated for 24 hours, and imaged using a digital camera. SGAtools was used to calculate average colony size and standard deviation across the plate for each media. Error bars represent mean $\pm \mathrm{SD}, *$, $\mathrm{p} \leq 0.05$, student $\mathrm{t}$ - test relative to control.

\subsubsection{The $A$. amatymbica extract affects various biological processes}

Hypersensitivity of gene deletion strains to an extract or compound indicates that gene and its associated pathway or process is involved in the bioactivity (Boone et al., 2007). Out of 
4,300 gene deletion strains in the $p d r 1 \Delta p d r 3 \Delta$ background, it was determined that 98 gene deletion mutants had significantly altered growth in $38 \mu \mathrm{g} / \mathrm{mL}$ A. amatymbica extracts compared to the vehicle control (Fig. 2.8). There were 54 and 44 mutants where growth was increased and decreased with the extract, respectively. As false positive results may exist in high-throughput assays, sensitivity was then validated using a low-throughput liquid growth assay. Each deletion mutant was treated with $25 \mu \mathrm{g} / \mathrm{mL}$ in liquid $\mathrm{CM}$ media, as this concentration gave approximately $20 \%$ growth inhibition in $p d r 1 \Delta p d r 3 \Delta$ in liquid, and residual growth was calculated compared to untreated controls of each strain. Of the 61 mutants that exhibited reduced growth in the high-throughput assay, five were confirmed to have significant growth defects when treated with A. amatymbica extract in the low-throughput assay (Fig. 2.9).

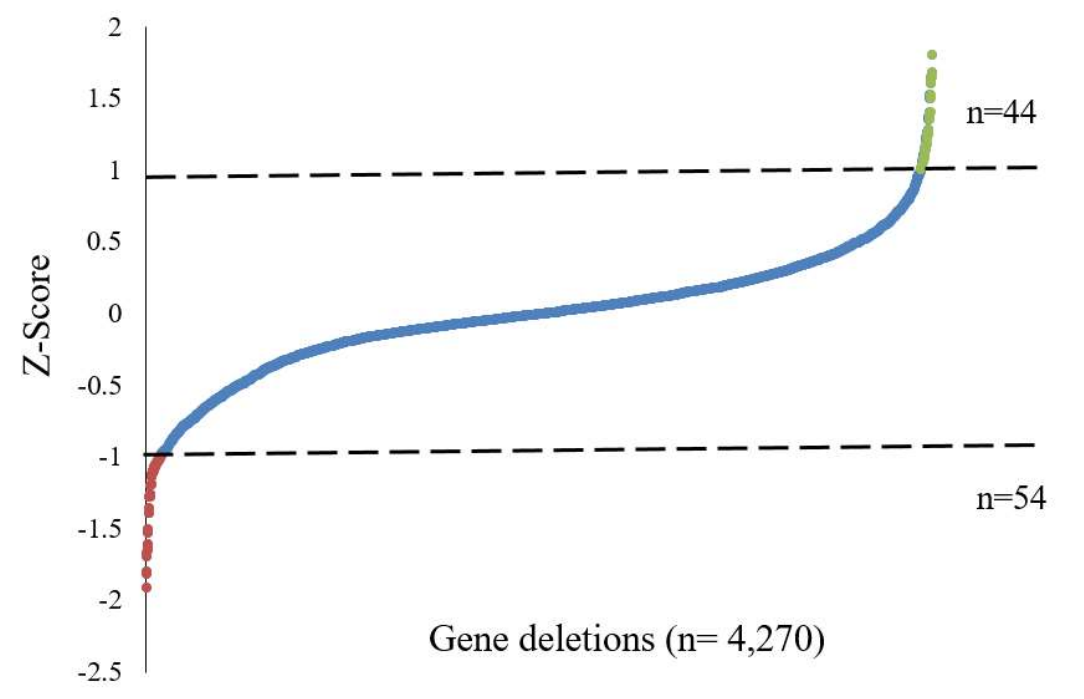

Figure 2.8: Sensitivity of 4,270 haploid gene deletion strains to the A. amatymbica extract. Each strain was quantified in quadruplicate where the growth ratio of treated to untreated cells is represented in the $\mathrm{Z}$-score; $\mathrm{Z}<-1$ reflects reduced growth in the extract (red) and $\mathrm{Z}>1$ reflects increased growth in the extract (green). Growth not significantly different in treated and untreated media were indicated in blue. 


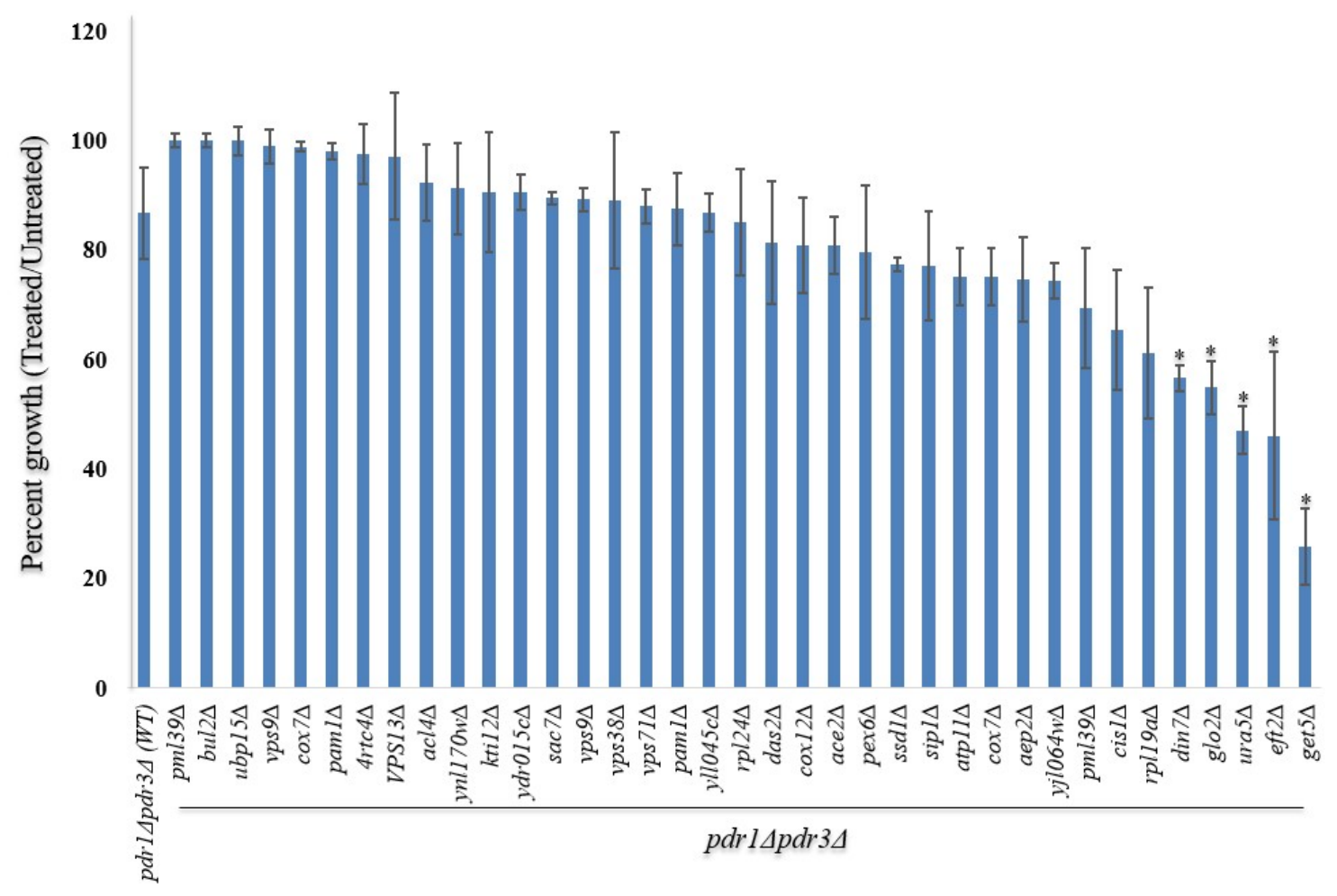

Figure 2.9: Low-throughput growth analysis confirms 5 gene deletion strains as sensitive to the $A$. amatymbica extract. Cells were inoculated in CM media treated with $25 \mu \mathrm{g} / \mathrm{mL}$ of the A. amatymbica extract. The growth was measured based on $\mathrm{OD}_{590}$ absorbance in treated compared to untreated cells. Error bars represent mean $\pm \mathrm{SD} .{ }^{*}, \mathrm{p} \leq 0.05$, student t- test relative to control.

\subsubsection{Functional annotation of genes altered by $A$. amatymbica extract}

The five gene deletion mutants sensitive to the A. amatymbica extract were processed through several enrichment analysis programs to annotate and understand the mechanism of action of the A. amatymbica extract. First, we searched for transcriptional regulation networks based on GO terms that are over-represented in the five genes relative to a random set of genes (Monteiro et al., 2019). The system classifies a list of input genes based on their regulatory associations with known transcription factors. 57, 26, 25, 24 and 42 transcription factors were associated with Get5, Din7, Glo2, Ura5 and Eft2 respectively. Nine of these regulators (Ino2, 
Yap1, Pdr3, Rpn4, Met32, Gcn4, Pdr1, Ndt80 and Cbf1) interact with all five sensitive genes (Fig. 2.10).

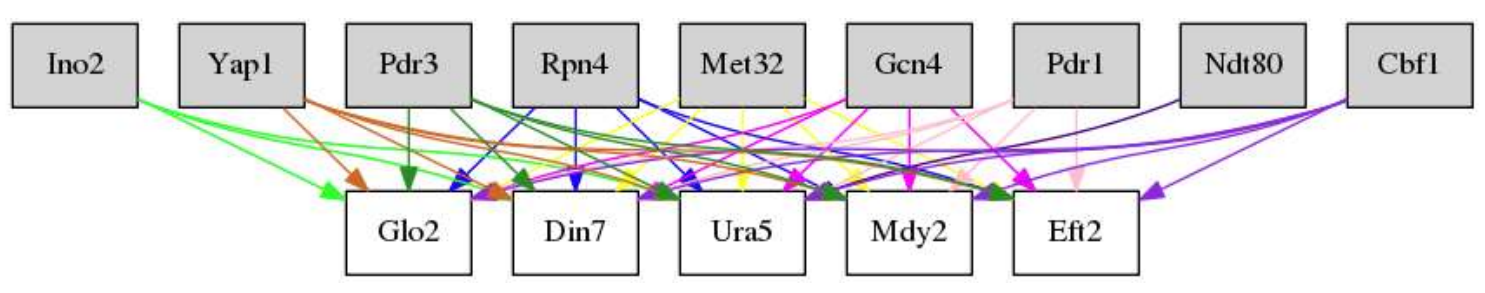

Figure 2.10: Transcriptional network regulating the five gene deletions sensitive to the $A$. amatymbica extract. Nine transcription factors (grey) either positively or negatively interact with the five sensitive genes.

A Spatial Analysis of Functional Enrichment (SAFE) analysis was also conducted on the five sensitive genes in the context of the yeast genetic interaction network. SAFE places a gene set into major functional domains (Baryshnikova et al., 2010; Usaj et al., 2017). Genetic interactions of the A. amatymbica extract gene set occurred within the domains of cytokinesis, tRNA wobble modification, peroxisome, mitochondria, vesicle trafficking and ribosome biogenesis (Fig. 2.11). Of which, vesicle traffic, peroxisome and mitochondria were significant $(\mathrm{P}<0.05)$ 


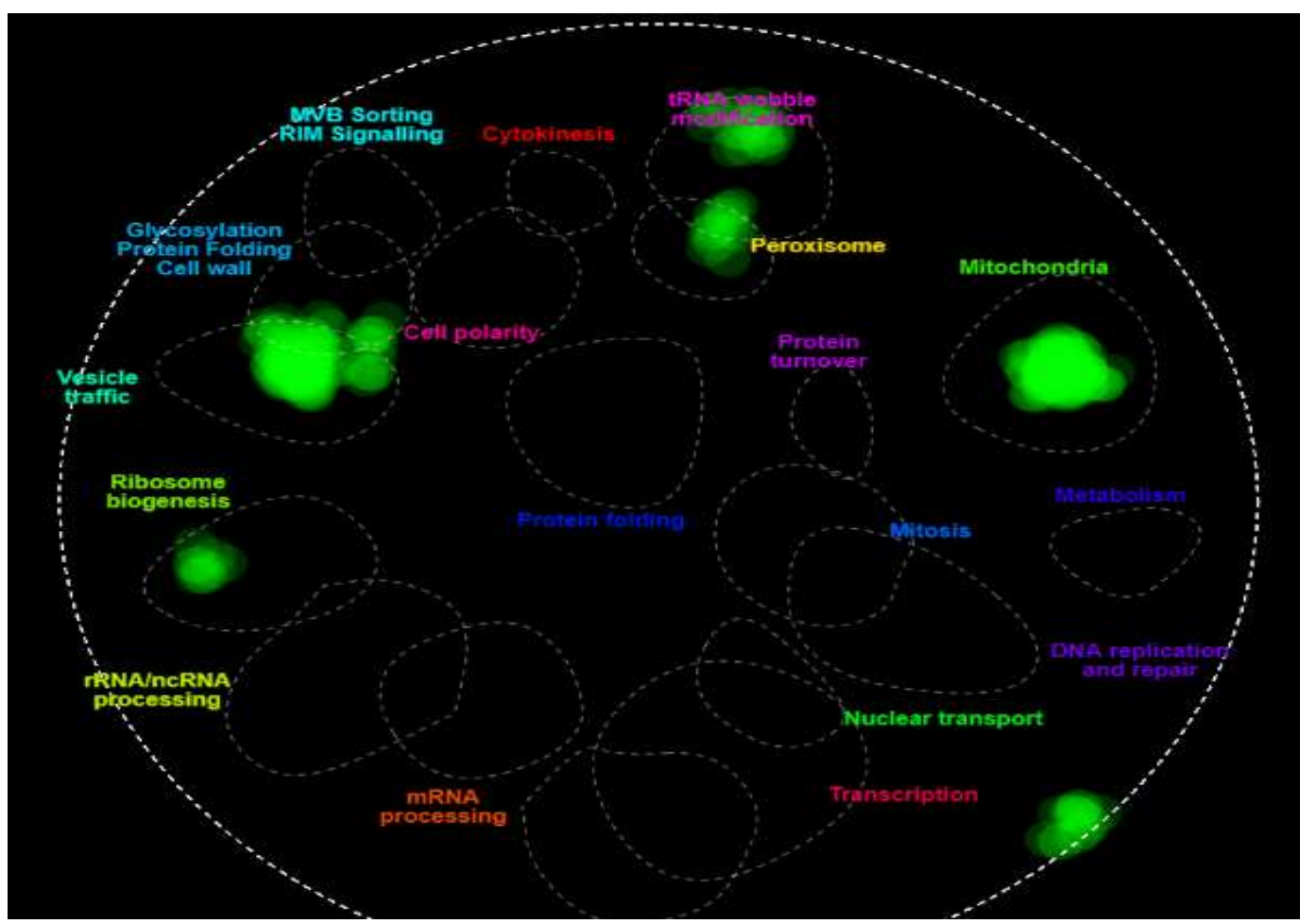

Figure 2.11: Spatial analysis for functional enrichment (SAFE) reveals enrichment for vesicle trafficking and mitochondria. The five sensitive genes were mapped to an annotated network. The increase in size and density of the green colour indicates association of the extract-sensitive genes and their interactions within the indicated functional domain in the network. 


\begin{tabular}{|l|l|}
\hline Gene & Description \\
\hline GET5 & $\begin{array}{l}\text { Protein with a role in insertion of tail-anchored proteins into the ER membrane; forms a } \\
\text { complex with Get4p; required for efficient mating; involved in shmoo formation and } \\
\text { nuclear migration in the pre-zygote; associates with ribosomes }\end{array}$ \\
\hline EFT2 & $\begin{array}{l}\text { Elongation factor 2 (EF-2), also encoded by EFT1; catalyzes ribosomal translocation } \\
\text { during protein synthesis; contains diphthamide, the unique posttranslationally modified } \\
\text { histidine residue specifically ADP-ribosylated by diphtheria toxin }\end{array}$ \\
\hline GLO2 & $\begin{array}{l}\text { Cytoplasmic glyoxalase II, catalyzes the hydrolysis of S-D-lactoylglutathione into } \\
\text { glutathione and D-lactate }\end{array}$ \\
\hline URA5 & $\begin{array}{l}\text { Major orotate phosphoribosyltransferase (OPRTase) isozyme that catalyzes the fifth } \\
\text { enzymatic step in de novo biosynthesis of pyrimidines, converting orotate into orotidine- } \\
5 \text { '-phosphate; minor OPRTase encoded by URA10 } \\
\text { DIN7 }\end{array}$ \\
$\begin{array}{l}\text { Mitochondrial nuclease functioning in DNA repair and replication, modulates the } \\
\text { suring meiosis at a time nearly coincident with commitment to recombination }\end{array}$ \\
\hline
\end{tabular}

Table 2.9: Annotation of the genes that were found to be sensitive to A. amatymbica extract.

Descriptions for each gene was obtained from Saccharomyces Genome Database (SGD).

The five gene deletion strains that showed significant reduced growth in the presence of the extract were analysed using gene ontology at three levels of classification (molecular function, biological process and cellular component). At the biological process level, there was significant enrichment for metabolic process (Fig. 2.12A). For the cellular component category, enrichment was significant for unclassified and mitochondrion (Fig. 2.12B), while there were significant enrichments for hydrolase activity and ion binding in the molecular function category (Fig. 2.12C). 


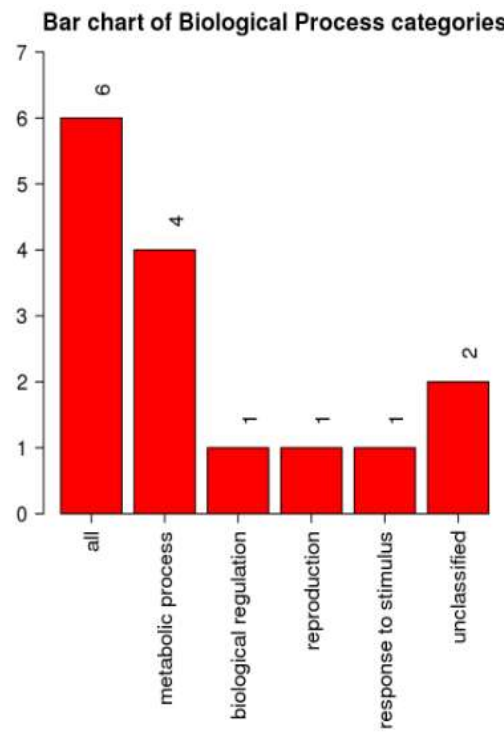

A

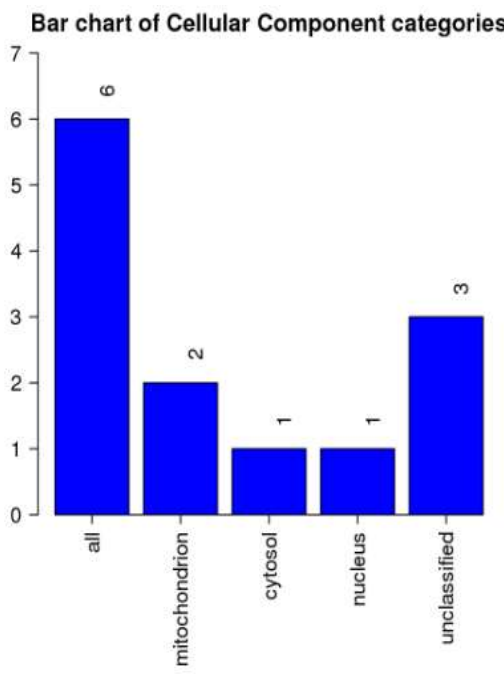

B

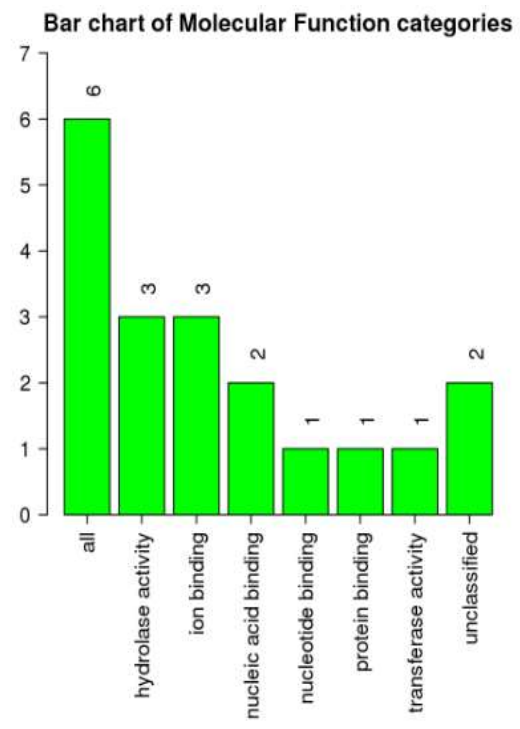

$\mathrm{C}$

Figure 2.12: GO enrichment analysis of 5 genes sensitive to A. amatymbica extract reveals several processes to be enriched for (A) molecular functions, (B) biological processes and (C) cellular components. Numbers above each bar indicate the number of genes associated with that category.

\subsubsection{Extract sensitivity in all members of the guided-entry tail anchored protein (GET)} family

The genome-wide analysis revealed one of the genes sensitive to A. amatymbica to be Get5 (Mdy2) (Fig. 2.9). Interestingly, Get5 has been implicated in tail anchored (TA) protein synthesis (Jonikas et al., 2009; Schuldiner et al., 2008). The guided entry tail anchored protein (GET) pathway uses several proteins (Get 1-5) to transport tail anchored proteins to the endoplasmic reticulum (Simpson et al., 2010). To determine if the GET complex was affected by $A$. amatymbica, a liquid assay was conducted on each member of the GET complex (Get 15) as well the chaperones Sgt2, Ssa1 and Ydp1 known to be involved in the GET pathway 
(Schuldiner et al., 2008). Relative to $80 \%$ residual growth in $p d r 1 \Delta 3 \Delta$, the $p d r 1 \Delta p d r 3 \Delta$ get $5 \Delta$ strain was most sensitive at $\sim 30 \%$ residual growth while $p d r 1 \Delta p d r 3 \Delta$ get $1 \Delta$ was less sensitive, albeit still significantly sensitive, at around $\sim 50 \%$ residual growth (Fig. 2.13). All chaperones were also sensitive where $p d r 1 \Delta p d r 3 \Delta s g t 2 \Delta, p d r 1 \Delta p d r 3 \Delta s s a 1 \Delta$ and $p d r 1 \Delta p d r 3 \Delta y d p 1 \Delta$ were each significantly sensitive with only $25-34 \%$ residual growth (Fig. 2.13). These results confirm the importance of the GET pathway and its associated chaperones in buffering the bioactivity of the $A$. amatymbica extract. 


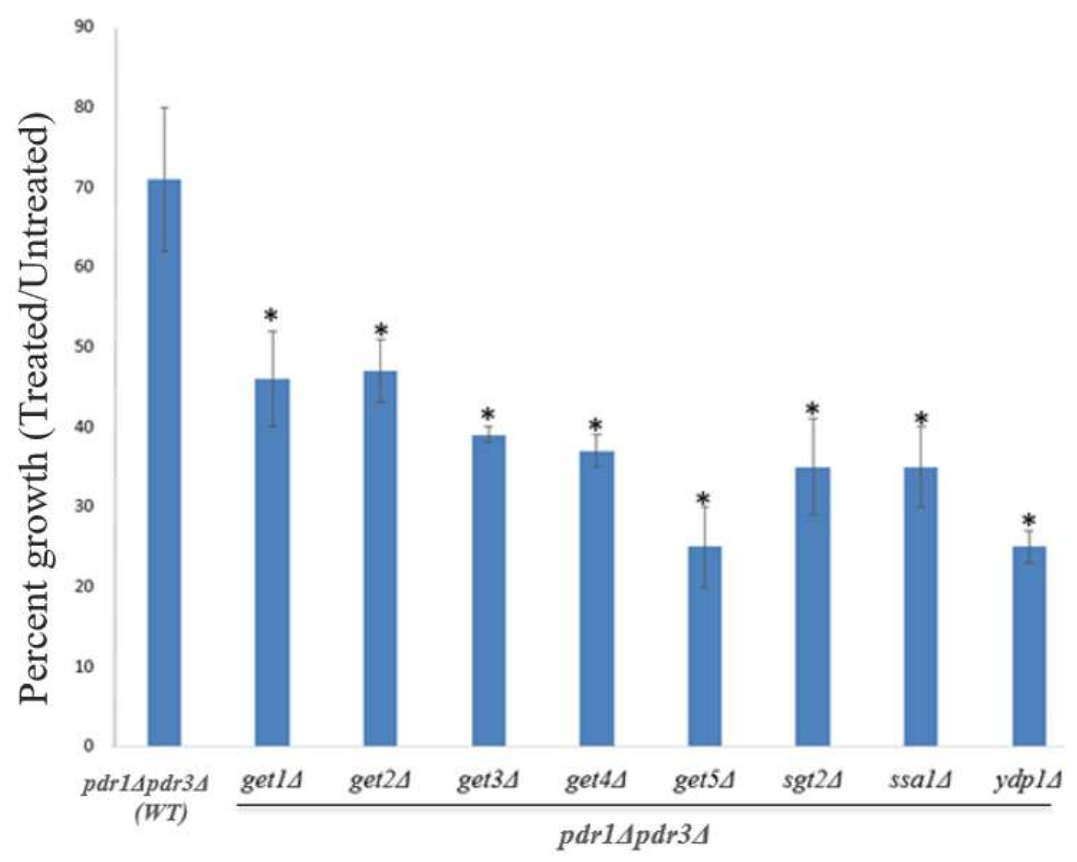

Figure 2.13: Sensitivity of genes involved in the guided entry tail anchored protein (GET) pathway to the A. amatymbica extract. Cells were inoculated in CM media treated with 25 $\mu \mathrm{g} / \mathrm{mL}$ of the $A$. amatymbica extract. The growth was measured based on $\mathrm{OD}_{590}$ absorbance in treated compared to untreated cells. Error bars represent mean $\pm \mathrm{SD} .^{*}, \mathrm{p} \leq 0.05$, student t-test relative to control.

\subsubsection{Compound B is less potent against guided-entry tail anchored protein (GET) deletion strains}

Since compound B was the most bioactive semi-purified fraction of the A. amatymbica extract (Fig. 2.5), it is plausible that compound B is the major bioactive specifically the compound mediating the sensitivity of the GET gene deletion strains. To determine if compound B was potent against the five GET gene deletions, a liquid growth assay was conducted. Relative to approximately $80 \%$ residual growth of $p d r 1 \Delta p d r 3 \Delta, p d r 1 \Delta p d r 3 \Delta$ get $1 \Delta$, $p d r 1 \Delta p d r 3 \Delta g e t 2 \Delta, p d r 1 \Delta p d r 3 \Delta g e t 3 \Delta$ and $p d r 1 \Delta p d r 3 \Delta$ get $4 \Delta$ exhibited residual growths at 
approximately $60 \%, 60 \%, 45 \%$ and $30 \%$ respectively (Fig. 2.14). pdr $1 \Delta p d r 3 \Delta$ get $5 \Delta$ was sensitive at around $30 \%$ residual growth. These results reveal that the GET complex buffers the effect of compound B, albeit compound B is not as potent as the A. amatymbica extract.

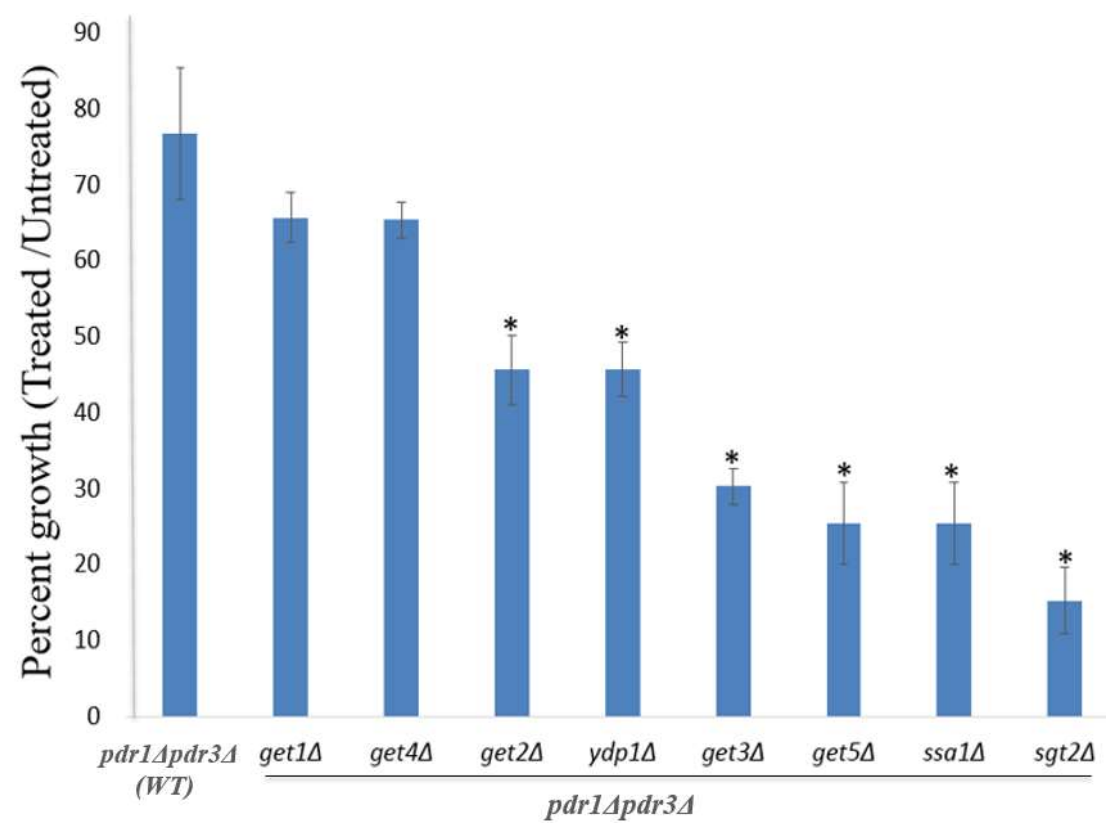

Figure 2.14: Sensitivity of genes involved in the guided entry tail anchored protein (GET) pathway to Compound B. Cells were inoculated in CM media treated with $25 \mu \mathrm{g} / \mathrm{mL}$ of compound B. The growth was measured based on $\mathrm{OD}_{590}$ absorbance in treated compared to untreated cells. Error bars represent mean $\pm \mathrm{SD}$. *, $\mathrm{p} \leq 0.05$, student t-test relative to control.

\subsubsection{Overexpression of GET3 in get1 $\Delta$ or get $2 \Delta$ increases extract bioactivity}

Overexpression of Get3 in the get $1 \Delta$ background has been observed to be lethal in the presence of GET substrates (Schuldiner et al., 2008). Get3 recognition is a key step in the biosynthesis of tail anchored (TA) proteins whose loss can lead to defective insertion of TA proteins into mitochondria (Schuldiner et al., 2008). In the absence of Get 1 and Get2, Get3-TA complexes aggregate in the cytosol leading defects in TA protein biogenesis (Schuldiner et al., 2008). To overexpress Get3 in $p d r 1 \Delta p d r 3 \Delta g e t 1 \Delta$ and $p d r 1 \Delta p d r 3 \Delta g e t 2 \Delta$ backgrounds, the gene 
deletions and overexpression had to be engineered, particularly since the pdr1 $\operatorname{pdr} 3 \Delta$ get $1 \Delta$ and pdr1 $4 p d r 3 \Delta g e t 2 \Delta$ strains used above could not be transformed with the Get3 overexpression plasmid containing uracil selection.

First, Get1 and Get2 genes were deleted using PCR-based gene deletion strategy (Baudin et al., 1993). GET1::LEU2 and GET2::LEU2 deletion cassettes were constructed using the $p U G 73$ plasmid as template and confirmed via electrophoresis on agarose gel where an expected 2,428bp was observed (Fig. 2.15). The PCR products were then transformed in $p d r 1 \Delta p d r 3 \Delta$. The genomic DNA of transformants was extracted, and PCR products specific for the gene deletions were amplified and electrophoresed on agarose gel where 2,949 bp expected bands confirmed the Get1 deletion (Fig. 2.16A) and 3,005 bp confirmed the Get2 deletion (Fig. 2.16B).

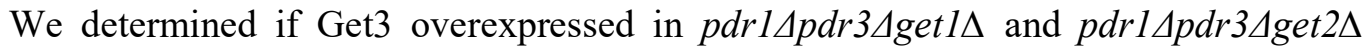
background was lethal in the presence of the A. amatymbica extract using an overexpression plasmid under the control of the GAL1 promoter. The $p d r 1 \Delta p d r 3 \Delta g e t 1 \Delta$ and $p d r 1 \Delta p d r 3 \Delta g e t 2 \Delta$ strains were grown overnight in raffinose where the GAL inducible GET3 was repressed, and then grown in either galactose (to induce GET3 overexpression) or glucose (to repress GET3 overexpression). Using agar medium that is more conventionally used in yeast with the GAL1 promoter, we determined if GET3 overexpression enhanced bioactivity of the A. amatymbica extract in $p d r 1 \Delta p d r 3 \Delta g e t 1 \Delta$ and $p d r 1 \Delta p d r 3 \Delta g e t 2 \Delta$ strains (Fig. 2.17). Overnight cultures grown in raffinose were inoculated on agar media containing glucose (to repress GET3 overexpression) or galactose (to induce GET3 overexpression). Relative to the empty vector where there was visible growth of $p d r 1 \Delta p d r 3 \Delta$ get $1 \Delta$ and $p d r 1 \Delta p d r 3 \Delta$ get $2 \Delta$ strains in galactose media with the $A$. amatymbica extract, there was no visible growth in these strains overexpressing GET3 in galactose media with the A. amatymbica extract (Fig. 2.17). This 
distinction was not seen in glucose media, thus these results reinforce the importance of the GET pathway as a mechanism buffering the bioactivity of the A. amatymbica extract.

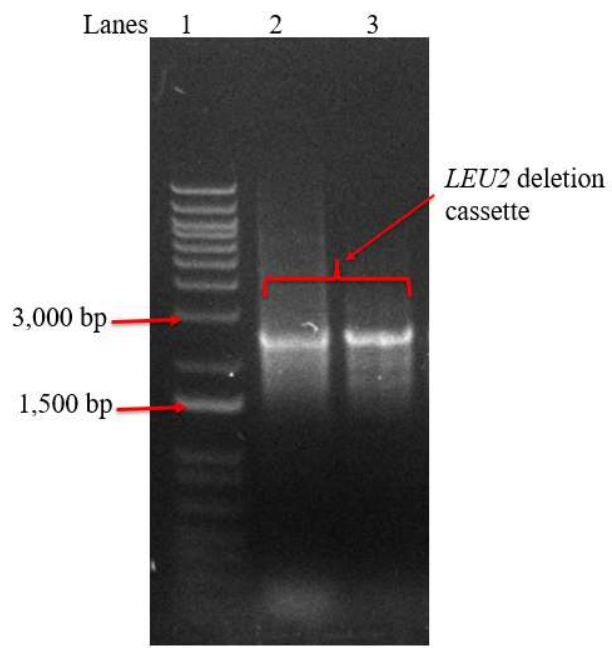

Figure 2.15: Construction of the GET1::LEU2 and GET2::LEU2 deletion cassettes. The deletion cassettes were amplified using the $p U G 73$ plasmid as template and PCR products were electrophoresed on 1\% agarose gel. Lane 1:1 -kb plus DNA ladder; Lane 2: GET1::LEU2 deletion cassette; Lane 3: GET2::LEU2 deletion cassette. 
A

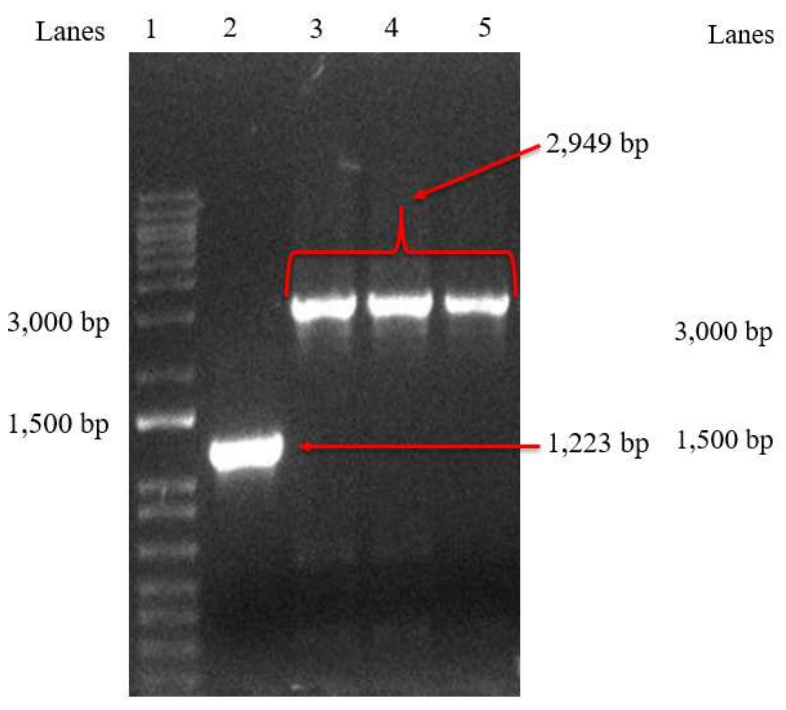

B

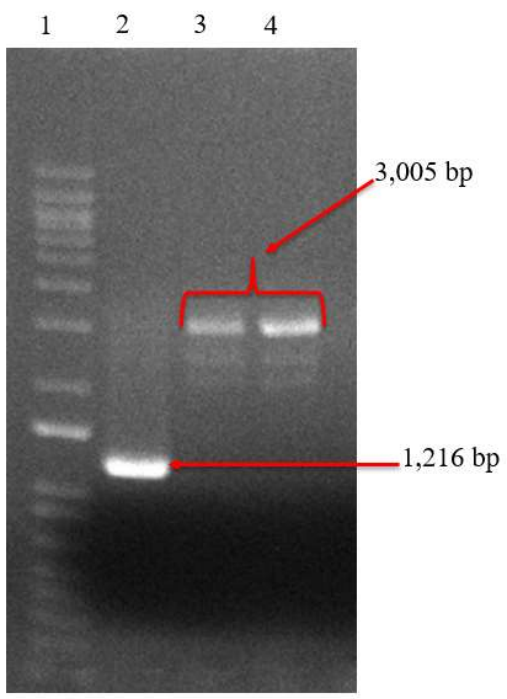

Figure 2.16: Confirmation of transformation of (A) get $\because: L E U 2$ and (B) get $2: \because L E U 2$ cassettes upon integration in the genome. The PCR products were amplified using primers specific for each locus in the genome and electrophoresed on 1\% agarose gel. (A) Lane 1: $1 \mathrm{~kb}$ plus DNA ladder; Lane 2. Wild type (no integration control); Lanes 3-5: Three independent transformants. (B) Lane 1: $1 \mathrm{~kb}$ plus DNA ladder; Lane 2. Wild type (no integration control); Lanes 3-4: Two independent transformants.

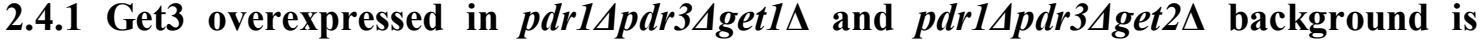
sensitive to $A$. amatymbica on agar

To see if overexpression of Get 3 in get $1 \Delta$ and get $2 \Delta$ background would be potent in a different media, the assay was conducted on agar. At $38 \mu \mathrm{g} / \mathrm{mL}$ of $A$. amatymbica the growth of Get3 overexpressed in get $1 \Delta$ background is visibly inhibited compared to glucose treatment and DMSO (Fig. 2.17). Growth inhibition is also seen when Get3 is overexpressed in get $2 \Delta$ background. 


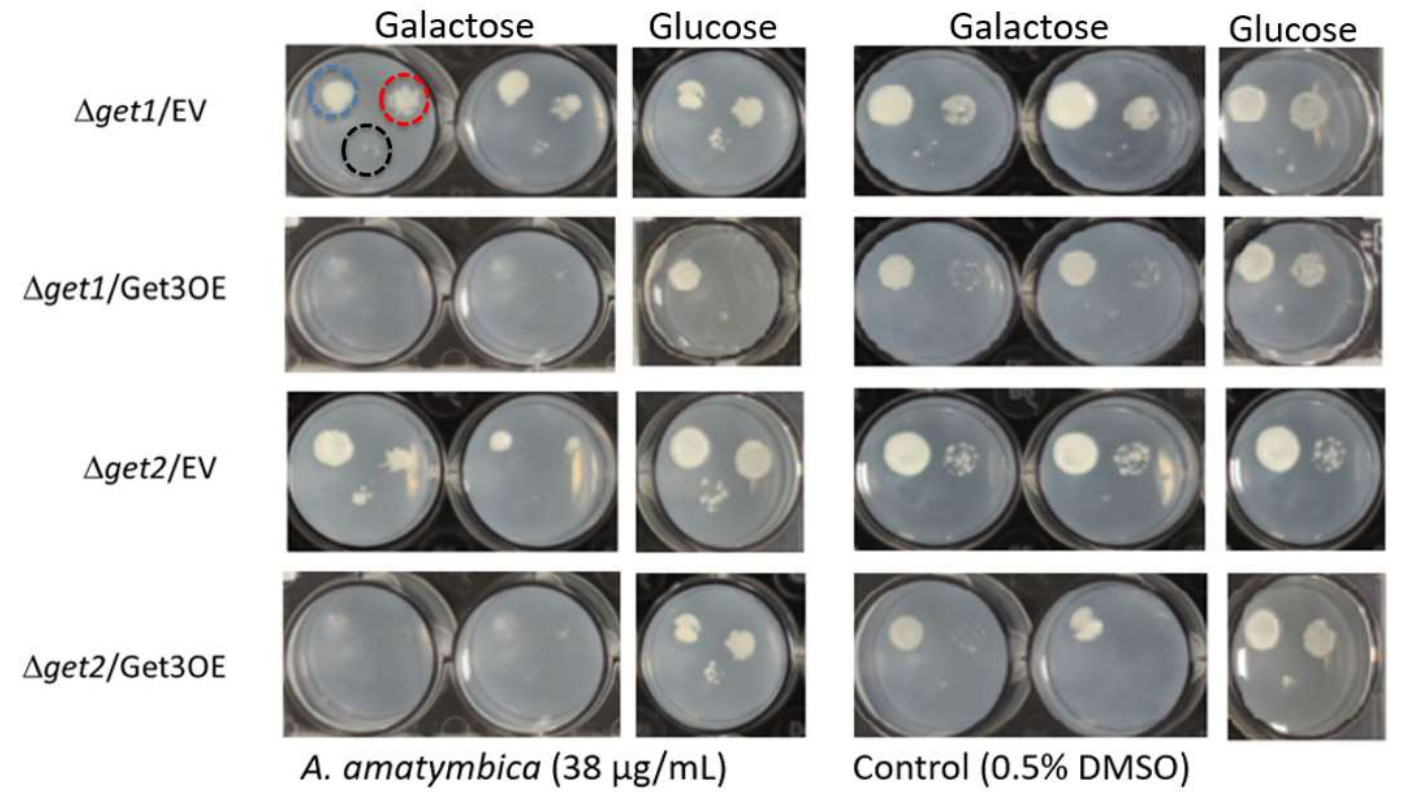

Figure 2.17: Over expressing Get3 in the presence of $A$. amatymbica on agar. Cells were spotted on agar treated with A. amatymbica or DMSO in either galactose or glucose. Spots represent 3 concentrations : $1 \times 10^{7}$ (blue), $1 \times 10^{5}$ (red) and $1 \times 10^{3}$ (Fischli et al.). Images were taken at $24 \mathrm{~h}$. EV, cells with empty vector plasmid. OE, cells with overexpression plasmid.

\subsubsection{SDS mimics pdr14pdr34 response}

With the results above confirming the importance of the GET pathway, we next sought to monitor localisation of the proteins specifically transported via the GET pathway. A libray of such GFP-tagged proteins exists (Weill et al., 2018); however, this library does not exist in the $p d r 1 \Delta p d r 3 \Delta$ background. We thus attempted to mimic the PDR-attentuated response by treating wild-type (BY4741) cells with sodium dodecyl sulfate (SDS). The addition of a small amount of SDS along with L-proline in the growth medium leads to a transient opening of the cell wall/membrane, thus increasing yeast cell permeability (Liu et al., 2007). Growth of wildtype cells treated with SDS was compared to $p d r 1 \Delta p d r 3 \Delta$ in CM media, whereby the $0.003 \%$ 
SDS treatment in BY4741 elicited a response similar to PDR-attentuated strain (Fig 2.18). Hence $0.003 \%$ SDS was used to investigate the impact of the A. amatymbica extract in the GFP-tagged strains in the BY4741 background.

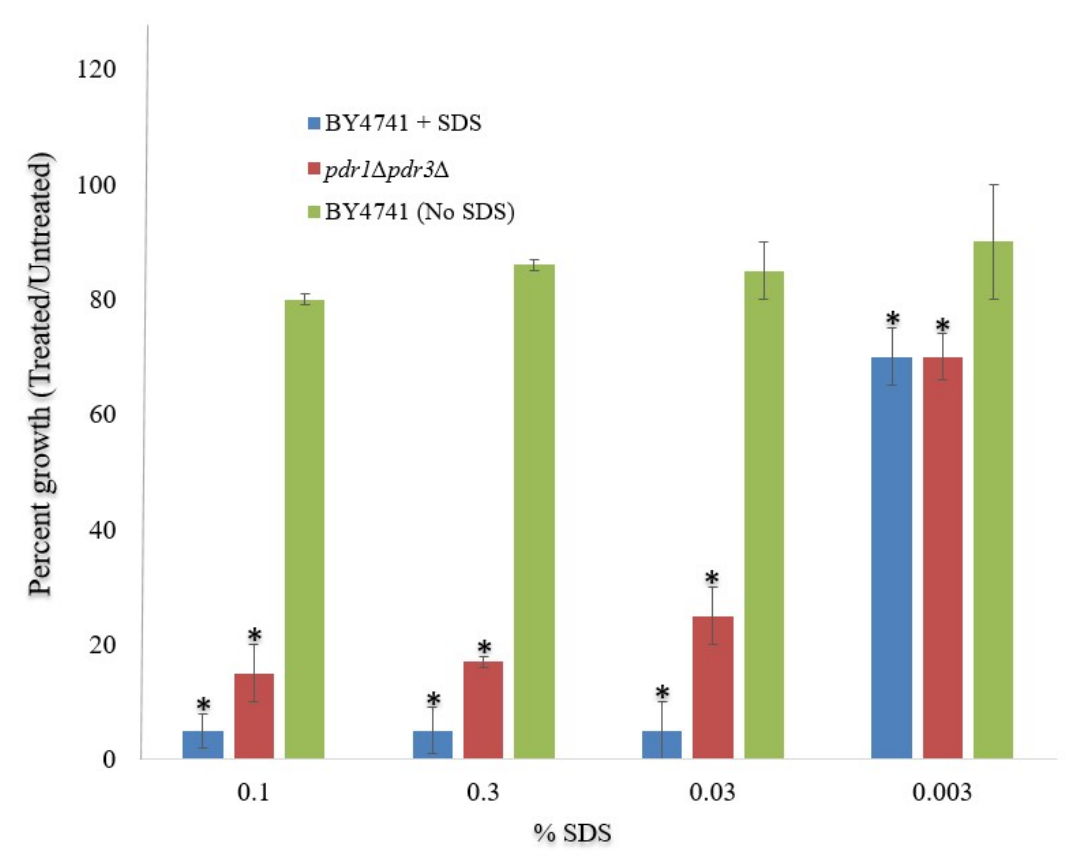

Figure 2.18: Wild-type (BY4741) yeast cells treated with $0.003 \%$ SDS mimics $p d r 1 \Delta p d r 3 \Delta$ response in CM media. BY4741 yeast cells were grown in SDS. pdr1 $1 p d r 3 \Delta$ was grown without SDS. Error bars represent mean \pm SD. ${ }^{*} \mathrm{p} \leq 0.5$, student $\mathrm{t}$ test compared to no SDS treatment.

\subsubsection{A. amatymbica extract does not affect GET mutants}

To investigate proteomic changes induced by $A$. amatymbica, a high throughput microscopy screen monitoring protein localisation was performed. Changes in protein localisation in response to chemical perturbation has been used to understand mechanisms of action (Tkach et al., 2012). Since the Get complex is important in mediating efficient targeting of TA proteins into the ER (Schuldiner et al., 2008), it is important to consider whether a defect 
in a Get gene in the presence of $A$. amatymbica leads to off-targeting of the TA protein. Using a SWAT NOP1promoter-GFP library (Weill et al., 2018), with GFP proteins tagged at the amine $(\mathrm{N})$ terminal, Get strains were observed under A. amatymbica treatment (Fig. 2.19). The images were analysed by eye to determine if there was an obvious change in localisation and were crossed checked by two different individuals for validation. Get3 and Get4 showed no obvious change in cytosolic localization of GFP between control and treatment. Likewise, no change in the expected ER localisation was observed in Get1 and Get2.

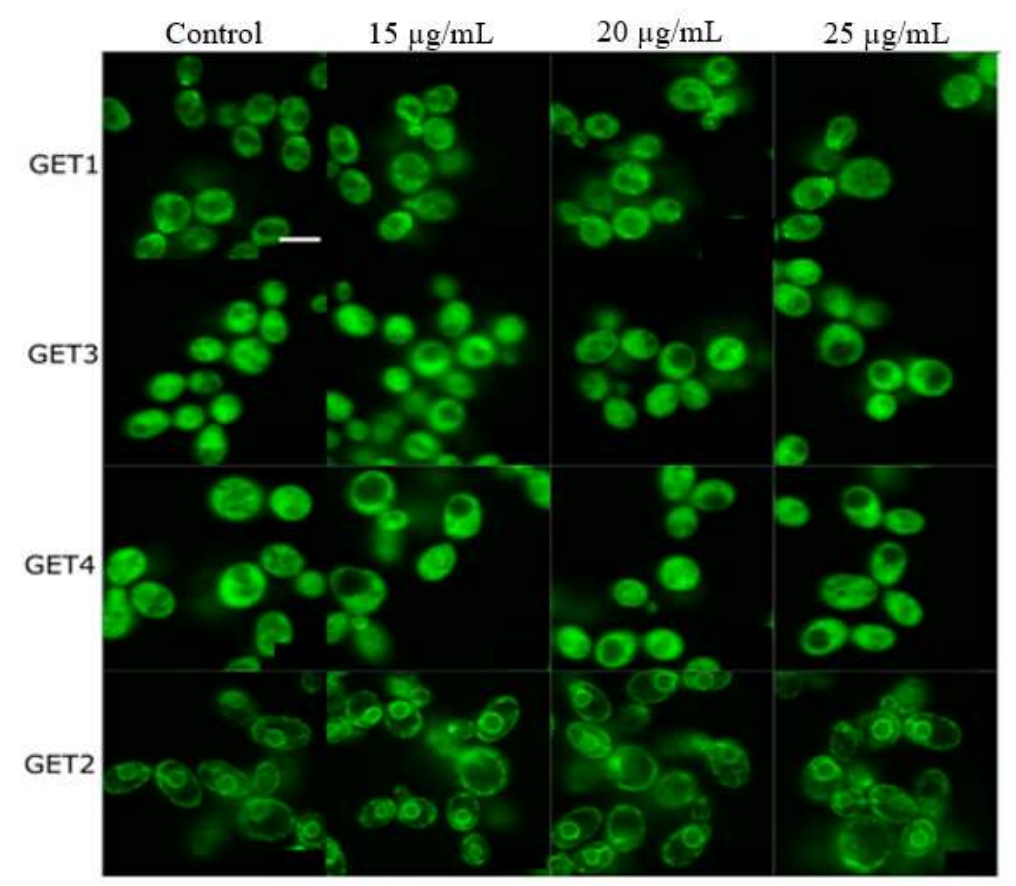

Figure 2.19: GET pathway is not affected by A. amatymbica treatment. Cells were treated with SDS for $2 \mathrm{~h}$ in CM media prior to A. amatymbica treatments at $15 \mu \mathrm{g} / \mathrm{mL}, 20 \mu \mathrm{g} / \mathrm{mL}$ and 25 $\mu \mathrm{g} / \mathrm{mL}$ and DMSO control for $4 \mathrm{~h}$. Images were visualised using a fluorescent microscope. Scale bar $=5 \mu \mathrm{m}$. 


\subsubsection{A. amatymbica affects ERG9 and CYB5 localisation}

Since targeting of TA proteins into the ER is mediated by the Get pathway (Schuldiner et al., 2008), it is important to consider whether TA proteins are mislocalized when treated with the A. amatymbica extract. Using the SWAT NOP-1promoter-GFP library (Weill et al., 2018), I screened 315 predicted TA proteins. This library is designed so that TA proteins are tagged with a GFP at the amine (N) terminal instead of the carboxyl (C) terminal end. This allows for more accurate targeting signal of TA proteins since C-tagged TA proteins are known to being wrongly localized or degraded (Weill et al., 2018). A change in predominant localisation from perinuclear ER to cortical ER was observed for both ERG9 and CYB5 at $20 \mu \mathrm{g} / \mathrm{mL}$ and 25 $\mu \mathrm{g} / \mathrm{mL}$ concentrations of $A$. amatymbica, compared to control (Fig. 2.20), while no change in punctate localization was observed in ERG6. Interestingly, ERG9 and CYB5 are both involved in lipid metabolism (Karst \& Lacroute, 1977; Truan et al., 1994). 


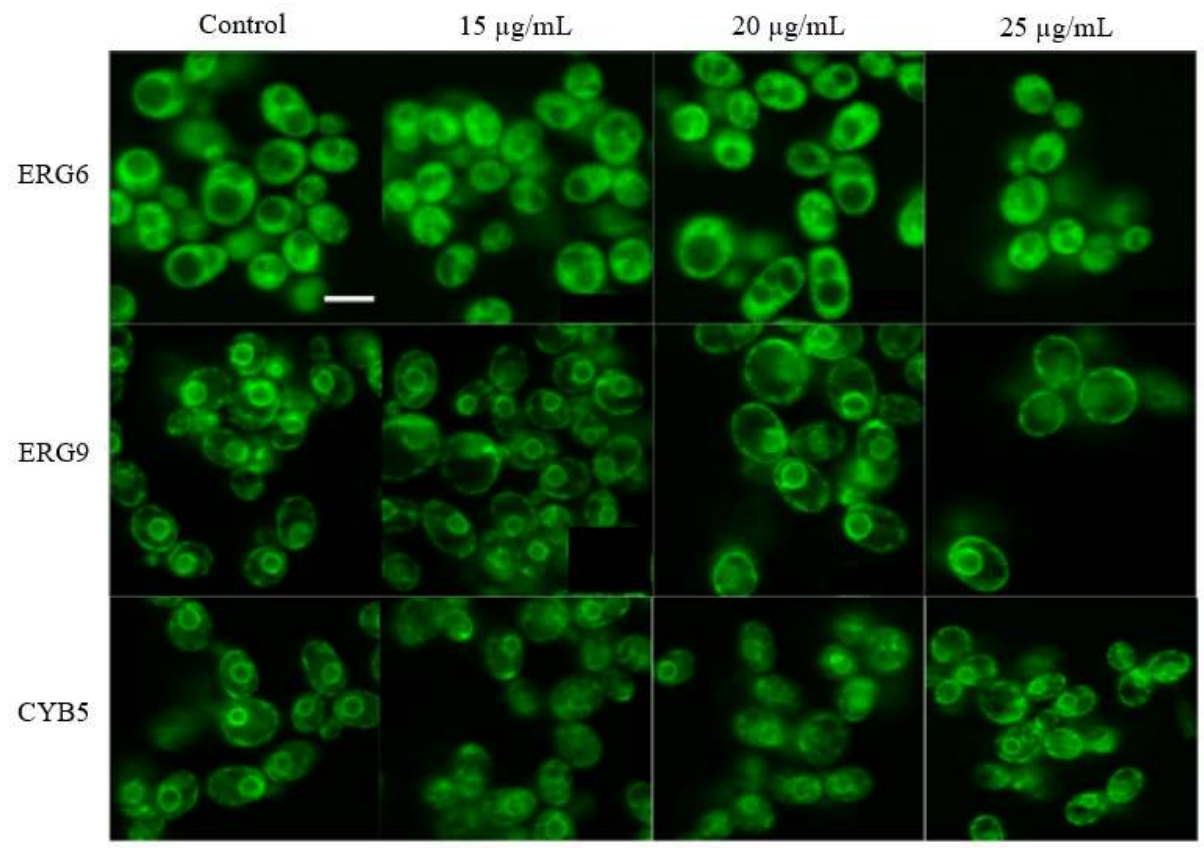

Figure 2.20: ERG9 and CYB5 are affected by A. amatymbica treatment. Cells were treated with SDS for $2 \mathrm{~h}$ in CM media prior to A. amatymbica treatments at $15 \mu \mathrm{g} / \mathrm{mL}, 20 \mu \mathrm{g} / \mathrm{mL}$ and $25 \mu \mathrm{g} / \mathrm{mL}$ and DMSO control for $4 \mathrm{~h}$. Images were visualised using a fluorescent microscope. Scale bar $=5 \mu \mathrm{m}$. 


\subsection{Discussion}

\subsubsection{Summary}

The aim of the thesis was to characterise the mechanism of action of the A. amatymbica extract and determine the most potent component of the extract. The A. amatymbica extract inhibited the growth of the PDR-attenuated yeast strain $p d r 1 \Delta p d r 3 \Delta$, showing that the extract is a potential substrate of the PDR drug efflux system. The unbiased approach of genome-wide analysis led to further analysis revealing mode of action for A. amatymbica involving the guided entry tail anchored (GET) protein pathway in yeast, orthologous transmembrane to the recognition complex (TRC) in humans. Gene deletions sensitive to A. amatymbica were also implicated in protein synthesis and pyrimidine synthesis. Furthermore, localisation of GFPtagged proteins regulated by the GET pathway showed a potential function of A. amatymbica in antioxidant activity and lipid metabolism. In addition, it was noted that compound B, a semipurified component of the $A$. amatymbica extract inhibited yeast growth similar to the crude extract of $A$. amatymbica, indicating that this compound is potentially the most potent component of bioactivity of $A$. amatymbica and potentially the major bioactive compound in the extract.

\subsubsection{A. amatymbica as a PDR substrate}

Increased xenobiotic sensitivity due to loss of function mutations in either the drug efflux transporters or their transcriptional regulators is a well-studied phenomenon (Coorey et al., 2015). The PDR network is comprised of an array of highly inducible drug efflux transporters encoded by the ATP binding cassette (ABC) superfamily and major facilitator superfamily (MFS) genes (Kolaczkowska \& Goffeau, 1999). The network is mainly controlled by two transcription factors: the binuclear $\mathrm{Zn}_{2} \mathrm{Cys}_{6}$ zinc finger protein $\mathrm{Pdr} 1 \mathrm{p}$ and its homolog 
Pdr3p and to a lesser extent by the bZIP family regulators Yrrlp and Yap1p. The PDR attenuated response allows for mechanism of action of xenobiotics that are PDR substrates, to be studied at a lower concentration (Coorey et al., 2015). Consistent with established PDR substrates including cycloheximide, fluconazole, ketoconazole, quercetin, amphotericin B and the natural products latrunculin A and plakortolide X (Coorey et al., 2015), the inhibition of pdr1 $\triangle p d r 3 \Delta$ at a lower $A$. amatymbica concentration (Fig. 2.3) compared to BY4741 suggests that A. amatymbica is potentially a substrate of the PDR. This is supported by the analysis showing Pdr1p and Pdr3p both interacting with five genes that are sensitive to A. amatymbica (Fig. 2.10). Compound B also inhibits the growth of $p d r 1 \Delta p d r 3 \Delta$ more so than BY4741 (Fig. 2.5) suggesting that compound $B$ is also a potential substrate of the PDR network. Taken together, this suggests that both the crude extract of $A$. amatymbica and compound $\mathrm{B}$ induce a xenobiotic stress response where the cells lacking the PDR1 and PDR3 master regulators of the PDR system, are not able to successfully pump out xenobiotics.

The involvement of the PDR system in the bioactivity of $A$. amatymbica has not been previously reported. A. amatymbica is known to inhibit the growth of Aspergillus flavus, Aspergillus niger, Penicillium notatum and Candida albicans (Afolayan \& Lewu, 2009). In these studies, the role of the drug efflux system was not reported where concentrations of 0.1 $5 \mathrm{mg} / \mathrm{mL}$ inhibited $50-80 \%$ growth of WT strains of these species presumably with functional PDR systems (Afolayan \& Lewu, 2009; Mulaudzi et al., 2009). For studies done on agar, Mulaudzi et al (2009) found 50\% growth inhibition growth on potato dextrose agar for Aspergillus flavus, Aspergillus niger and Penicillium notatum in $0.1-5 \mathrm{mg} / \mathrm{mL}$ A. amatymbica (Mulaudzi et al., 2009). 50-80\% growth inhibition observed previously at $5 \mathrm{mg} / \mathrm{mL}$, albeit in different fungal species, seem comparable with observations in this thesis where visible inhibition was observed at $6 \mathrm{mg} / \mathrm{mL}$ A. amatymbica (Fig.2.6). Difference in fungal species aside, the comparability in A. amatymbica potency between presumably PDR-replete and PDR- 
attenuated strains could be explained by possible differences in sourcing of plant material since extracts made from wild plants are more potent than extracts made from cultivated plants (Rustaiyan \& Sadjadi, 1987). Hence, the down-regulation of the PDR system does not necessarily negate the traditional use of A. amatymbica in treating antifungal infections (Afolayan \& Lewu, 2009), or alternatively raises concern about concentrations used in traditional medicine compared to yeast cells in this thesis. The bioactivity of A. amatymbica in both the presence and absence of the drug efflux pump suggests a broad range of cellular targets underlying its traditional use. Further laboratory assays of the crude extract and active compounds will be required in order to better understand the involvement of the PDR system in the bioactivity of $A$. amatymbica, relative to its traditional use.

\subsubsection{A. amatymbica potentially affects guided entry for tail-anchored protein (GET)}

In the presence of A. amatymbica, all five GET mutant strains (pdr1 1 pdr3 $\Delta$ get1 1 , pdr1 $4 p d r 3 \Delta g e t 2 \Delta, p d r 1 \Delta p d r 3 \Delta g e t 3 \Delta, p d r 1 \Delta p d r 3 \Delta g e t 4 \Delta, p d r 1 \Delta p d r 3 \Delta g e t 5 \Delta$ ) showed reduced growth (Fig. 2.13). The guided entry of tail anchored protein (GET) pathway uses these 5 genes to post-translationally conduct tail-anchored (TA) proteins to the endoplasmic reticulum (ER) where they are inserted into the lipid bilayer before they are directed to their respective destinations in the secretory pathway (Simpson et al., 2010). Hence, reduced growth when these genes are absent, suggests these gene deletions buffer the effect of $A$. amatymbica extract.

Briefly, the GET pathway begins with Sgt2 recognizing a TA protein emerging from the ribosome, forming Sgt2-TA complex (Chang et al., 2012; Zhang et al., 2021). Next, Get4 and Get5 form a 'scaffolding complex' where Sgt2-TA complex is recruited at the Get5 domain, while Get4 recruits Get3 (Chang et al., 2012). A “hand-off” reaction follows resulting in TA protein transfer from Sgt2 to Get3 (Mateja \& Keenan, 2018). Get3 then dissociates from 
Get4 and is directed to the Get1/Get receptor complex located at the ER. At the ER, Get1/2 disrupts the TA protein binding site in Get3, releases the TA protein for insertion into the ER and Get3 is recycled to the cytosol to initiate a new round of targeting (Rabu et al., 2009).

Consistent with this model, $p d r 1 \Delta p d r 3 \Delta g e t 1 \Delta$ and $p d r 1 \Delta p d r 3 \Delta g e t 2 \Delta$ show similar sensitivity in the presence of the crude extract of A. amatymbica (Fig. 2.13), although this appears not to be the case with compound B (Fig. 2.14). This suggests the functions of Get1/Get2 are potentially required to buffer the effects of A. amatymbica. However, the

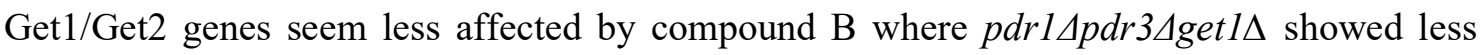
growth inhibition in comparison to crude $A$. amatymbica extract (Fig. 2.14). It is plausible that due to redundancy in TA insertion pathway, other pathways are recruited in the presence of compound B but not in crude A. amatymbica extract. One such pathway is the chaperonedependent pathway (Chang et al., 2010). This is supported by lower sensitivity of the chaperone mutant strain $y d p 1 \Delta$ in compound B (Fig. 2.14) compared to crude $A$. amatymbica extract (Fig. 2.13). Another pathway known to serve as back up to GET in yeast, is the signal recognition independent targeting pathway, which involves Snd1, Snd2 and Snd3. These genes were found to synthetically compensate for the loss of both the signal recognition particle and GET pathways, and act as a backup targeting system (Aviram et al., 2016). Hence, in the presence of these alternative pathways, there is a possibility of TA targeting occurring independently of GET leading to differences in sensitivities in the GET genes to A. amatymbica in this study.

Since Get1/Get2 receptor is required for recruiting Get3-TA protein complexes, and the loss of either Get1 or Get2 causes Get3-TA complexes to aggregate in the cytosol (Schuldiner et al., 2008), we sought to investigate whether overexpressing Get3 when either Get1 or Get2 is absent, would increase sensitivity to the A. amatymbica extract. As predicted, mutants overexpressing Get3 in both $p d r 1 \Delta p d r 3 \Delta$ get $1 \Delta$ and $p d r 1 \Delta p d r 3 \Delta g e t 2 \Delta$ background were more sensitive to A. amatymbica compared to mutants lacking the Get3 overexpression plasmid 
(Fig.2.17). This suggests Get1/Get2 is potentially involved in buffering the activity of $A$. amatymbica.

Furthermore, the sensitivity of $p d r 1 \Delta p d r 3 \Delta g e t 5 \Delta$ to both the crude A. amatymbica extract (Fig. 2.13) and compound B (Fig. 2.14), and that of pdr1 $\Delta p d r 3 \Delta \operatorname{sgt} 2 \Delta$ (Fig. 2.13) suggests the activity of $A$. amatymbica is buffered by the functions of Get5 and Sgt2 which occurs further upstream in the GET pathway. With chaperones also sensitive (Fig. 2.13), and none of the deletion strains showing significant resistance, this supports the earlier mentioned possibility that other pathways are simultaneously involved in buffering the activity of $A$. amatymibca with regards to TA biosynthesis. The redundancy in pathways is common in yeast, where genes performing related functions are distributed on alternate pathways to compensate for the blockage of one pathway (Li et al., 2010). For A. amatymbica, this study has shown one of the pathways buffering its effect, potentially with regards to TA biosynthesis, to be the GET pathway.

\subsubsection{Potential function in the TRC40 pathway}

As mentioned earlier, Get3 is an important component of the GET pathway (Schuldiner et al., 2008), whose sensitivity to A. amatymbica (Fig. 2.13; Fig. 2.14) has not been previously studied. In mammalian cells, the orthologue of Get3, known as TRC40 or Asna1, is a component of transmembrane recognition complex (Bozkurt et al., 2009; Colombo et al., 2016), known to be inhibited by a number of compounds (Van Puyenbroeck \& Vermeire, 2018).

Since A. amatymbica extract and compound B both led to sensitivity in the GET mutants (Fig. 2.13; Fig. 2.14), it is important to consider the potential effects the extract and compound may have in the transmembrane recognition complex pathway. Interestingly, Sec61, 
a gene encoding membrane proteins that mediate ER protein translocation (Potenza et al., 1992), is a known drug target in the transmembrane recognition complex pathway (McKenna et al., 2016). Mycolactone, a natural product produced by Mycobacterium ulcerans, is known to inhibit the transmembrane complex by non-selectively inhibiting Sec61-dependent translocation across ER (McKenna et al., 2016), while suppressing the inflammatory cytokine (Grotzke et al., 2017). Similarly, the Pseudomonas aeruginosa protein, exotoxin A, is known to indirectly target the Sec61 channel, keeping it in a closed state by competing with the cytosolic protein calmodium for binding site on Sec61 $\alpha$ (Wirth et al., 2003). The fungal macrocycle, cotransin, prevents access of proteins to the ER lumen by inhibiting signal peptidedependent gating of the Sce61 (Klein et al., 2015). Apratoxin A, a secondary metabolite isolated from a marine cyanobacterium, has been hypothesized to inhibit co-translational translocation by down-regulating a subset of membrane proteins (Liu et al., 2009). Sec61 is also a known target of eeyarestatin I, which prevents nascent chain transfer to Sec61 in the signal recognition pathway (Cross et al., 2009).

Since drugs often share molecular targets (AY et al., 2007), and pathways in yeast are conserved in higher eukaryotes (Aviram et al., 2016), future studies could compare mechanisms of action for A. amatymbica with these other compounds that work through the TRC40 pathway. These experiments could occur in yeast or mammalian cells.

\subsubsection{Potential function in antioxidant activity}

Din7 is a mitochondrial nuclease involved in DNA repair and replication and modulates the stability of the mitochondrial genome (Table 2.9). This activity is supported by functional annotation analysis showing significant enrichment for mitochondria (Fig. 2.11; Fig. 2.12B). A possible factor relating to this activity is the defective insertion of the TA proteins into 
mitochondrial membrane in the absence of a functional Get1/Get2 receptor at the ER (Vitali et al., 2018). Since this was not confirmed by protein localization assay (Fig. 2.19), it is plausible that our treatment (concentration or time) was not potent enough to mimic genetic deletions in that publication, or alternatively, that the off-targeting did not occur as predicted.

Considering that $\operatorname{din} 7 \Delta$ is sensitive to $A$. amatymbica (Fig. 2.9), it is plausible that $A$. amatymbica elicits an antioxidant response. Though antioxidant activity of $A$. amatymbica has not been well studied, the antioxidant properties of ent-kaurene diterpenes, the type of compound that is compound B, have been suspected (Thirugnanasampandan et al., 2008). Ent kaurene diterpenoid melissoidesin, isolated from the acetone extract of the leaves of Isodon wightii, exhibited promising antiacetylcholinesterase and antioxidant properties that can be used in food and drug preparations (Thirugnanasampandan et al., 2008). Thus the potential antioxidant properties of $A$. amatymbica could be attributed to Compound B- a kaurene diterpene.

Furthermore, the anti-oxidant potential of A. amatymbica is consistent with previous studies examining the anti-inflammatory activity of the extract (Mulaudzi et al., 2009), since the antioxidant activities of phenolic and flavonoid compounds are known to also exhibit antiinflammatory activity (Arulselvan et al., 2016). Taken together, this provides preliminary evidence to validate the traditional use of A. amatymbica as an anti-inflammatory agent (Afolayan \& Lewu, 2009).

\subsubsection{Potential anti-cancer activity of $\boldsymbol{A}$. amatymbica}

Glo2 is part of the glyoxalase system, which detoxifies methylglyoxal and other endogenous harmful metabolites into non-toxic $d$-lactate, protecting the cell from damage and apoptosis (Antognelli et al., 2017). Yeast cells lacking Glo2 gene were sensitive to $25 \mu \mathrm{g} / \mathrm{mL}$ 
of $A$. amatymbica (Fig. 2.9). Since Glo2 gene has been implicated in various types of cancers (Antognelli et al., 2017; de Bari et al., 2021; Hosoda et al., 2015) and the gene is under the regulatory control of Yap1p (Fig. 2.10), a potent oncogene that is amplified in these cancerous cells (Huang et al., 2005), it is important to consider the potential anti-cancer activity of $A$. amatymbica.

The glyoxalase system is an enzymatic network found in the cytosol of all mammalian cells consisting of Glo2, Glo1 and reduced glutathione (He et al., 2020). The system has been associated with various conditions including neurodegenerative disorders and cancer (He et al., 2020). Dysregulation of Glo2 is known to cause prostate tumorigenesis (Xu \& Chen, 2006) and lung cancer (Antognelli et al., 2017), and has been found to be mediated by the natural product oleuropein, a polyphenolic compound enriched in olive oil (de Bari et al., 2021).

The anti-cancer activity of $A$. amatymbica has previously been studied in various cancer cell lines where anti-cancer activity was suspected to be attributed to the inhibition of lipoxygenase activities (Muleya et al., 2017) and the antioxidant activity of A amatymbica (Wintola \& Afolayan, 2014). The known interplay between anti-cancer and antioxidant activities (de Bari et al., 2021) complements the results of this study which suggests a potential function of $A$. amatymbica in both of these activities. However, the anti-cancer activity of $A$. amatymbica has not previously been studied in the context of glyoxalase activity. Future studies could investigate the glyoxalase system as a potential pathway for anti-cancer activity of $A$. amatymbica. This will further support the traditional use of the plant as a cancer prevention treatment (Wintola \& Afolayan, 2014). 


\subsubsection{Potential function for $A$. amatymbica in lipid metabolism}

Lipids have gained much attention recently due to their involvement in health and disease (Klug \& Daum, 2014). Lipid metabolism involves a number of organelles mainly the ER, the Golgi apparatus, and the mitochondria (Fagone \& Jackowski, 2009). A class of membrane lipids, the sterols, are primarily synthesized in the ER prior to transport (Peretti et al., 2008). In yeast, the major sterol is ergosterol (Erg), which is the end product of the yeast sterol biosynthetic pathway, the equivalent of mammalian cholesterol (Henneberry \& Sturley, 2005). The ergosterol pathway involves a number of ERG genes interacting with different pathways (Jordá \& Puig, 2020) including, interestingly, cytochrome b5 (Cyb5), a known electron donor (Lamb et al., 1999).

When exposed to A. amatymbica extract, GFP tagged- Erg9 and Cyb5 both showed to a slight decrease in protein abundance and a slight change in localisation from perinuclear ER to cortical ER for Erg9 (Fig. 2.20). Eukaryotic cells are known to rapidly adjust the size, shape, and composition of organelles when met with changing physiological demands (Schmidt et al., 2019). Although such phenotypes possibly relate to ER membrane expansion associated with unfolded-protein response (UPR) (Schuck et al., 2009), UPR was not investigated in this study. However, the involvement of Erg9 and Cyb5 with this phenotype, genes which are involved in lipid metabolism and ER membrane biogenesis (Papagiannidis et al., 2021), suggests $A$. amatymbica potentially buffers the processes in these pathways.

Since Erg9 and Cyb5 are each involved in sterol and lipid biosynthesis (Karst \& Lacroute, 1977; Truan et al., 1994), it is important to consider the potential activity of $A$. amatymbica extract in lipid metabolism. Using the HIP-HOP chemogenomics database (Lee et al., 2014), Get5-deficiency was most sensitive to the delta (9) fatty acid desaturase (OLE1) pathway. Delta (9) fatty acid desaturase (OLE1) is required for monounsaturated fatty acid synthesis and for normal distribution of mitochondria by catalysing the double bond formation 
between carbons 9 and 10 of palmitoyl and stearoyl coenzyme A (Stukey et al., 1989). The involvement of Get5 in OLEI pathway complements the phenotype observed with Erg9 and Cyb5 (Fig. 2.20) in relation to a possible function of $A$. amatymbica extract in sterol and lipid biosynthesis

Furthermore, since the diterpene, compound B, elicits similar sensitivity in pdr1 $\Delta p d r 3 \Delta g e t 5 \Delta$ (Fig. 2.14), it is plausible that compound B is involved in lipid metabolism. Although no lipid metabolism studies have been done on A. amatymbica to date, a study of diterpenes, albeit diterpene alkaloids, isolated from the medicinal plant Nigella sativa, found potent lipid metabolism activity in primary mouse hepatocytes (Morikawa et al., 2004). These activities mirror that of clofibrate (Morikawa et al., 2004), a peroxisome proliferator-activated receptor alpha (PPAR- $\alpha$ ) agonist (Pan et al., 2018) known to be neuroprotective against neuroinflammation, neurotoxicity, neuronal damage and axonal injury (Moreno \& Cerù, 2015; Oyagbemi et al., 2020). Interestingly, these neuroprotective effects are associated with antioxidant and anti-inflammatory properties (Gray et al., 2012), reinforcing the antioxidant potential of $A$. amatymbica extract as discussed earlier. Hence, this possibly validates the medicinal use of A. amatymbica (Afolayan \& Lewu, 2009). Further, since kaurene-type diterpenes are a major bioactive component of A. amatymbica (Afolayan \& Lewu, 2009), including compound $\mathrm{B}$, this suggests a potential role of these compounds in lipid metabolism.

\subsubsection{Potential function in protein synthesis}

The sensitivity of yeast cells lacking the Eft2 gene when treated with A. amatymbica suggests a potential function of the extract in protein synthesis (Fig. 2.9). Protein synthesis as performed by ribosome, is well conserved in eukaryotes (von der Haar, 2008). Yeast cells synthesize around 13,000 proteins per second (Shah et al., 2013). In this process, the elongation 
factor 2 (EF2), plays an essential role by catalysing ribosomal translocation (Justice et al., 1998).

The elongation factor 2 is a known target of antifungal drugs (Domínguez \& Martín, 1998). The sordarin family of compounds, is known to block ribosomal translocation by stabilizing the fungal EF2-ribosome (Chiba et al., 2006). Sodarins are diterpene metabolites isolated from the fungus Sordaria araneosa (Pongcharoen et al., 2008). The antifungal drug fusidic acid, a triterpene, isolated from the fungus Fusidium coccineum (Brahmachari, 2019), also targets the elongation factor and inhibits the ribosomal peptide elongation and ribosomal recycling (Borg et al., 2015). With $p d r 1 \Delta p d r 3 \Delta$ eft $2 \Delta$ being sensitive to A. amatymbica (Fig. 2.9), analyses revealing significant enrichment for ribosome biogenesis and tRNA wobble modification (Fig. 2.11), and the involvement of the transcriptional activator- Gen $4 p$ (Fig.2.10), this suggests a potential function of Eft 2 in buffering the effects of A. amatymbica extract in protein synthesis. Further, since diterpenes are known to target the Eft 2 protein, albeit fungal diterpenes, there is potentially a role of compound B in this bioactivity as structurally similar compounds often share biological activities (Martin et al., 2002).

Taken together, the results provide some validation of the traditional use of $A$. amatymbica as an antifungal medicine (Wintola \& Afolayan, 2014), with the mechanism of action targeting protein synthesis, potentially attributable to the diterpenic components such as compound B. This could be the subject of future investigations.

\subsubsection{Potential anti-viral activity of $A$. amatymbica}

The traditional use of $A$. amatymbica extract as an antiviral medicine has not been fully studied (Louvel et al., 2013; Otang et al., 2012). For common respiratory RNA viruses, a suspected mechanism of action for antiviral drugs involves the inhibition of the viral 
pyrimidine biosynthesis pathway (Cheung et al., 2017). This is because to replicate efficiently, viruses not only depend on their hosts for an adequate supply of pyrimidine nucleotides, but also up-regulate pyrimidine nucleotide biosynthesis in infected cells (Okesli et al., 2017). A compound screen, done by Kao et al (2010), revealed FA-613, an inhibitor of de novo pyrimidine biosynthesis, to be potent against various virus strain including SARS and MERS coronavirus (Cheung et al., 2017; Kao et al., 2010). This compound was found to interfere with the de novo pyrimidine synthesis by targeting the dihydroorate dehydrogenase (Kao et al., 2010).

In yeast cells lacking the Ura5 gene, $25 \mu \mathrm{g} / \mathrm{mL}$ of crude $A$. amatymbica extract led to a $60 \%$ growth inhibition, relative to $20 \%$ in wild-type (Fig. 2.9). Interestingly, Ura5 gene is involved in de novo biosynthesis of pyrimidines (Table 2.9). Ura5 encodes the enzyme orotate phosphoribosyltransferase (OPRTase) which catalyses the fifth enzymatic step of the process. The sensitivity of $p d r 1 \Delta p d r 3 \Delta$ ura5 4 to A. amatymbica suggests the Ura5 might be involved in buffering the effects of $A$. amatymbica. This in turn potentially infers bioactivity in de novo pyrimidine biosynthesis. Altogether, this may support the antiviral claims of A. amatymbica in traditional medicine. Further, pyrimidine synthesis inhibition is known to induce host innate immunity (Kao et al., 2010), which might help in potential clinical development of $A$. amatymbica as a potential antiviral drug. However future studies could further investigate the activity A. amatymbica is having on Ura5.

\subsubsection{Potential variation in the bioactivity of $A$. amatymbica}

The bioactivity of $A$. amatymbica could have varied throughout the course of the thesis for several reasons. This may have been due to factors that are known to affect the bioactivity of natural products (Yilmaz \& Karadeniz, 2014). One of these is to do with storage. Studies 
conducted on African medicinal plants have shown noticeable differences in phytochemical properties between fresh and stored samples (Laher et al., 2013; Yilmaz \& Karadeniz, 2014). These differences might be due to stability of compounds. It is plausible that storage of $A$. amatymbica extract at $-20^{\circ} \mathrm{C}$ and continuous thawing and freezing may have had an effect on the bioactivity of the extract with each use. Shelf-life is especially important for natural products with pharmaceutical potential since the potency of these compounds needs to be guaranteed (Cheong et al., 2018). Although the effect of storage on bioactivity of $A$. amatymbica was not specifically monitored in this study, crude extract of A. amatymbica and compound B remained more potent to $p d r 1 \Delta p d r 3 \Delta$ (Fig. 2.3) compared to BY4741, suggesting there was not a significant change in bioactivity.

Another aspect to consider is the plant part from which the extract was obtained and whether the plant is cultivated or grown in the wild (Louvel et al., 2013). It has been observed that $A$. amatymbica grown in the wild were more potent compared to plants that were cultivated (Mangoale \& Afolayan, 2020), while there was little difference in potency between the part of the plant used and the type of extract prepared (Mangoale \& Afolayan, 2020).

\subsection{Conclusion}

To conclude, this thesis investigated the bioactivity of A. amatymbica, a traditional medicine of Eastern and South Africa. Using yeast as a model organism, the project aimed to determine the potential mechanism of action of the A. amatymbica extract. Initial phenotypic screening of the crude extract and the semi purified compound B showed that A. amatymbica extract is a potential substrate of the PDR system in yeast. A genome-wide analysis, using the haploid deletion collection in the $p d r 1 \Delta p d r 3 \Delta$ background, revealed significant enrichment for mitochondrial function, tRNA wobble modification and ribosome biogenesis. We revealed five 
genes that when deleted showed significantly reduced growth in the presence of A. amatymbica extract compared to the untreated control. Of these, $p d r 1 \Delta p d r 3 \Delta$ get $5 \Delta$ was the most sensitive. Since Get5 is a member of the Get complex, the sensitivity of rest of the Get family was evaluated in low-throughput liquid assay. The entire Get family, as well as their interacting the chaperones were found to buffer A. amatymbica extract bioactivity. Further, evaluation of the

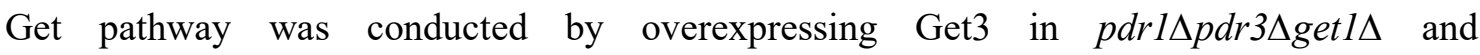
$p d r 1 \Delta p d r 3 \Delta$ get $2 \Delta$ coincident with $A$. amatymbica extract treatment. This was meant to cause cytosolic aggregation of Get3-TA proteins leading to added stress and hence increased sensitivity to A. amatymbica extract. We further conducted a proteomic analysis using an Nterminally tagged GFP library, to investigate the mislocalization of TA protein when the cells are treated with $A$. amatymbica extract. We showed changes in localization of ER proteins (Erg9 and Cyb5), suggesting a potential function in lipid metabolism. This coincides with a potential antioxidant activity given the sensitivity of $\operatorname{din} 7 \Delta$ to $A$. amatymbica extract whereby Din7 is a mitochondrial nuclease which modulates the stability of the mitochondrial genome. Furthermore, this activity may relate to the anti-cancer activity of $A$. amatymbica extract with pdr1 $\Delta p d r 3 \Delta g l o 2 \Delta$ also being sensitive to the extract. Finally two other genes, Eft 2 and Ura5, found to be sensitive to A. amatymbica extract suggests potential functions of A. amatymbica extract in protein synthesis and anti-viral activity. Taken together, the activity of $A$. amatymbica extract encompasses interaction with the Get complex, with potential functions in antioxidant and anti-cancer activity, lipid metabolism, protein synthesis and pyrimidine biogenesis. 


\subsection{Future directions}

Unfortunately, time did not allow for further characterization of the bioactivity of $A$. amatymbica extract. At the end of the thesis, there are questions that remain unanswered. The following assays could be carried out in the future to further study the role of GET complex in the bioactivity of $A$. amatymbica extract. Additionally, the potential antioxidant and lipid metabolism functions of $A$. amatymbica extract could be explored.

\subsection{Genome-wide screen of gene deletion in a PDR-positive background}

Although the study was based on $p d r 1 \Delta p d r 3 \Delta$ strain due to limited amount of $A$. amatymbica extract and compound B, future study could explore the bioactivity in wild-type (BY4741) strain, albeit this will require more extract and compound. Using a yeast deletion library (Giaever \& Nislow, 2014), a genome wide screen could be conducted to determine strains that are sensitive in the presence of the PDR system. Sensitivity of yeast to a functioning PDR system could be compared to sensitivity when the PDR system has been down regulated. This would help understand the antifungal traditional use of A. amatymbica in medicinal applications where the PDR system is functional when the A. amatymbica extract is consumed orally.

\subsection{Localization of TA proteins}

Since SDS was used to mimic the PDR response in the part of the study that monitored localization of TA proteins, it is not known whether the SDS treatment is having a similar effect to a PDR-attenuated strain or whether the master regulators, Pdrlp and Pdr3p, are still functional and actively contributing in drug efflux. The latter would have contributed to less potency in $A$. amatymbica. A GFP screen done in the $p d r 1 \Delta p d r 3 \Delta$ background, would 
determine the changes in TA protein localization in response to A. amatymbica when the PDR system is not functional. If all things equal, the same result will be obtained, which would then inform a change in an experiment condition specifically treatment with A. amatymbica for more than four hours. Also, since yeast membranes permeabilised with SDS are known to affect cell viability by allowing entry of various toxins and leakage of cellular content (Pannunzio et al., 2004), it is unknown how much of an effect this has had on the experiment.

Furthermore, since the study was done using a subset of GFP library where proteins are tagged to the $\mathrm{N}$ terminal, it is not known what the effect of A. amatymbica is in a C-terminally tagged library, suggesting a possible future experiment that monitors localisation of all proteins, not just TA proteins.

\subsection{Characterisation of lipid metabolism}

Further study could be done to investigate the potential lipid metabolism activity of $A$. amatymbica. The Erg9p and Cyb5p proteins are both involved in sterol metabolism of which lipid droplets serve a critical function in sterol esterification. Lipids can be measured in cells treated with $A$. amatymbica (Patel et al., 2019). If $A$. amatymbica affects lipid metabolism, changes in the number of lipid droplet in treatment compared to control will be observed. The

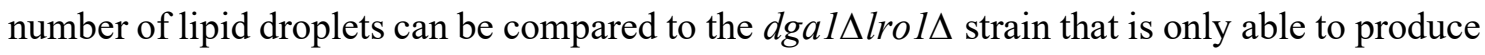
one lipid per cell (Choudhary et al., 2011).

Further, the function of A. amatymbica in ergosterol biosynthesis could be studied in the context of ERG9, which encodes squalene synthase Erg9p, responsible for converting diphosphate to squalene (Jennings et al., 1991). In mutant yeast lacking the ERG9 gene, the amount of squalene could be observed when treated with the extract to confirm if the extract is a substrate at squalene synthase step of ergosterol biosynthesis. 


\subsection{Reactive oxygen species assay}

To confirm the antioxidant activity of $A$. amatymbica, an analysis of reactive oxygen species (ROS) could be done. ROS are highly reactive metabolites of oxygen, such as superoxide, hydrogen peroxide $\left(\mathrm{H}_{2} \mathrm{O}_{2}\right)$, and peroxynitrite (Dikalov \& Harrison, 2014). Since antioxidants can react with ROS to produce stable products, the level of ROS could be used to determine if $A$. amatymbica exhibits an antioxidant effect by reducing the level of ROS. ROS can be measured in the absence of the Tpk3p gene in yeast, which is known to regulate mitochondrial biogenesis and when absent, causes the mitochondria to produce large amounts of ROS (Chevtzoff et al., 2010). Alternatively, studies could be done with yeast cells lacking the Sodl gene that detoxifies superoxide radicals produced during aerobic respiration and its deletion renders yeast hypersensitive to oxygen (Martins \& English, 2014). If in the presence of $A$. amatymbica, the growth of sod1 1 is rescued, this will support the antioxidant activity of the extract.

\subsection{Identifying the target of $\boldsymbol{A}$. amatymbica}

To better understand the bioactivity of $A$. amatymbica extract, other approaches could be taken. One approach is by using a heterozygous deletion library which identifies genes that require one copy to be sensitive to a treatment, i.e. haploinsufficiency. This method was successfully used to identify the target of rapamycin (Gibbons et al., 2009). A proteomic profiling could also be done (Tashiro \& Imoto, 2012). For this, various expression profiles of cells under compound treatment are compared against expression profiles of other known compounds. Since compounds with similar expression profiles have similar modes of action (Cong et al., 2012), a profile that is comparable to A. amatymbica extract would determine potential targets of $A$. amatymbica extract. 


\section{Bibliography}

Abdullahi, A. A. (2011). Trends and challenges of traditional medicine in Africa. African Journal of Traditional, Complementary, and Alternative Medicines : AJTCAM, $8(5$ Suppl), 115-123.

Afolayan, A. J., \& Lewu, F. B. (2009). Antimicrobial activity of Alepidea amatymbica. Pharmaceutical Biology, 47(5), 436-439.

Antognelli, C., Ferri, I., Bellezza, G., Siccu, P., Love, H. D., Talesa, V. N., \& Sidoni, A. (2017). Glyoxalase 2 drives tumorigenesis in human prostate cells in a mechanism involving androgen receptor and p53-p21 axis. Molecular Carcinogenesis, 56(9), 2112-2126.

Antognelli, C., Ferri, I., Bellezza, G., Siccu, P., Love, H. D., Talesa, V. N., \& Sidoni, A. (2017). Glyoxalase 2 drives tumorigenesis in human prostate cells in a mechanism involving androgen receptor and p53-p21 axis. Mol Carcinog, 56(9), 2112-2126.

Arnold, T. H., Prentice, C. A., Hawker, L. C., Snyman, E. E., Tomalin, M., Crouch, N. R., \& Pottas-Bircher, C. (2002). Medicinal and Magical Plants of Southern Africa: An Annotated Checklist. Pretoria: National Botanical Institute.

Arulselvan, P., Fard, M. T., Tan, W. S., Gothai, S., Fakurazi, S., Norhaizan, M. E., \& Kumar, S. S. (2016). Role of Antioxidants and Natural Products in Inflammation. Oxidative medicine and cellular longevity, 2016, 5276130-5276130.

Ashburner, M., Ball, C. A., Blake, J. A., Botstein, D., Butler, H., Cherry, J. M., Sherlock, G. (2000). Gene ontology: Tool for the Unification of Biology. The Gene Ontology Consortium. Nature genetics, 25(1), 25-29.

Ast, T., Cohen, G., \& Schuldiner, M. (2013). A Network of Cytosolic Factors Targets SRPIndependent Proteins to the Endoplasmic Reticulum. Cell, 152(5), 1134-1145.

Atanasov, A. G., Zotchev, S. B., Dirsch, V. M., Orhan, I. E., Banach, M., Rollinger, J. M., the International Natural Product Sciences, T. (2021). Natural products in Drug Discovery: Advances and Opportunities. Nature Reviews Drug Discovery.

Aviram, N., Ast, T., Costa, E. A., Arakel, E. C., Chuartzman, S. G., Jan, C. H., Schuldiner, M. (2016). The SND Proteins Constitute an Alternative Targeting Route To The Endoplasmic Reticulum. Nature, 540(7631), 134-138.

AY, M., Goh, K.-I., Cusick, M. E., Barabasi, A.-L., \& Vidal, M. (2007). Drug Target Network. Nature biotechnology, 25(10), 1119-1127.

Baker Brachmann, C., Davies, A., Cost, G. J., Caputo, E., Li, J., Hieter, P., \& Boeke, J. D. (1998). Designer Deletion Strains Derived From Saccharomyces cerevisiae S288C: A Useful Set of Strains and Plasmids for PCR-mediated Gene Disruption and Other Applications. Yeast, 14(2), 115-132.

Baker, D. D., Chu, M., Oza, U., \& Rajgarhia, V. (2007). The Value of Natural Products to Future Pharmaceutical Discovery. Nat Prod Rep, 24(6), 1225-1244.

Baltz, R. H. (2008). Renaissance in Antibacterial Discovery from Actinomycetes. Curr Opin Pharmacol, 8(5), 557-563.

Baryshnikova, A., Costanzo, M., Dixon, S., Vizeacoumar, F. J., Myers, C. L., Andrews, B., \& Boone, C. (2010). Synthetic Genetic Array (SGA) Analysis in Saccharomyces cerevisiae and Schizosaccharomyces pombe. Methods Enzymol, 470, 145-179.

Baudin, A., Ozier-Kalogeropoulos, O., Denouel, A., Lacroute, F., \& Cullin, C. (1993). A simple and efficient method for direct gene deletion in Saccharomyces cerevisiae. Nucleic Acids Research, 21(14), 3329-3330.

Birnboim, H. C., \& Doly, J. (1979). A rapid alkaline extraction procedure for screening recombinant plasmid DNA. Nucleic Acids Research, 7(6), 1513-1523.

Boone, C., Bussey, H., \& Andrews, B. J. (2007). Exploring genetic interactions and networks with yeast. Nature Reviews Genetics, 8(6), 437-449. 
Borg, A., Holm, M., Shiroyama, I., Hauryliuk, V., Pavlov, M., Sanyal, S., \& Ehrenberg, M. (2015). Fusidic acid targets elongation factor $\mathrm{G}$ in several stages of translocation on the bacterial ribosome. The Journal of Biological Chemistry, $290(6), 3440-3454$.

Bozkurt, G., Stjepanovic, G., Vilardi, F., Amlacher, S., Wild, K., Bange, G., Sinning, I. (2009). Structural insights into tail-anchored protein binding and membrane insertion by Get3. Proceedings of the National Academy of Sciences, 106(50), 21131.

Bracegirdle, J., Stevenson, L. J., Page, M. J., Owen, J. G., \& Keyzers, R. A. (2020). Targeted Isolation of Rubrolides from the New Zealand Marine Tunicate Synoicum kuranui. Marine drugs, 18(7), 337.

Brahmachari, G. (2019). 1 - Therapeutics from natural products against neglected tropical diseases: an overview. In G. Brahmachari (Ed.), Discovery and Development of Therapeutics from Natural Products Against Neglected Tropical Diseases (pp. 1-6): Elsevier.

Busia, K. (2005). Medical provision in africa - past and present. Phytotherapy Research, 19(11), 919-923.

Butler, M. S. (2005). Natural products to drugs: natural product derived compounds in clinical trials. Natural Product Reports, 22(2), 162-195.

Buwa, L. V., \& van Staden, J. (2006). Antibacterial and antifungal activity of traditional medicinal plants used against venereal diseases in South Africa. J Ethnopharmacol, 103(1), 139-142.

Chang, Y.-W., Chuang, Y.-C., Ho, Y.-C., Cheng, M.-Y., Sun, Y.-J., Hsiao, C.-D., \& Wang, C. (2010). Crystal Structure of Get4-Get5 Complex and Its Interactions with Sgt2, Get3, and Ydj1. The Journal of biological chemistry, 285, 9962-9970.

Chang, Y.-W., Lin, T.-W., Li, Y.-C., Huang, Y.-S., Sun, Y.-J., \& Hsiao, C.-D. (2012). Interaction surface and topology of Get3-Get4-Get5 protein complex, involved in targeting tail-anchored proteins to endoplasmic reticulum. The Journal of Biological Chemistry, 287(7), 4783-4789.

Cheong, A. M., Tan, C. P., \& Nyam, K. L. (2018). Stability of Bioactive Compounds and Antioxidant Activities of Kenaf Seed Oil-in-Water Nanoemulsions under Different Storage Temperatures. J Food Sci, 83(10), 2457-2465.

Cheung, N. N., Lai, K. K., Dai, J., Kok, K. H., Chen, H., Chan, K. H., Kao, R. Y. T. (2017). Broad-spectrum inhibition of common respiratory RNA viruses by a pyrimidine synthesis inhibitor with involvement of the host antiviral response. J Gen Virol, 98(5), 946-954.

Chevtzoff, C., Yoboue, E. D., Galinier, A., Casteilla, L., Daignan-Fornier, B., Rigoulet, M., \& Devin, A. (2010). Reactive oxygen species-mediated regulation of mitochondrial biogenesis in the yeast Saccharomyces cerevisiae. The Journal of Biological Chemistry, 285(3), 1733-1742.

Chiba, S., Kitamura, M., \& Narasaka, K. (2006). Synthesis of (-)-Sordarin. Journal of the American Chemical Society, 128(21), 6931-6937.

Choudhary, V., Jacquier, N., \& Schneiter, R. (2011). The topology of the triacylglycerol synthesizing enzyme Lro1 indicates that neutral lipids can be produced within the luminal compartment of the endoplasmatic reticulum: Implications for the biogenesis of lipid droplets. Communicative \& Integrative Biology, 4(6), 781-784.

Clardy, J., \& Walsh, C. (2004). Lessons from natural molecules. Nature, 432(7019), 829-837.

Clemons, P. A. (2004). Complex phenotypic assays in high-throughput screening. Curr Opin Chem Biol, 8(3), 334-338.

Colombo, S. F., Cardani, S., Maroli, A., Vitiello, A., Soffientini, P., Crespi, A., Borgese, N. (2016). Tail-anchored Protein Insertion in Mammals: Function and reciprocal 
interactions of the two subunits of the TRC40 receptor. The Journal of Biological Chemistry, 291(29), 15292-15306.

Cong, F., Cheung, A. K., \& Huang, S. M. (2012). Chemical genetics-based target identification in drug discovery. Annu Rev Pharmacol Toxicol, 52, 57-78. doi:10.1146/annurevpharmtox-010611-134639

Coorey, N. V., Matthews, J. H., Bellows, D. S., \& Atkinson, P. H. (2015). Pleiotropic drugresistance attenuated genomic library improves elucidation of drug mechanisms. Mol Biosyst, 11(11), 3129-3136. doi:10.1039/c5mb00406c

Coorey, N. V. C., Matthews, J. H., Bellows, D. S., \& Atkinson, P. H. (2015). Pleiotropic drugresistance attenuated genomic library improves elucidation of drug mechanisms. Molecular BioSystems, 11(11), 3129-3136.

Cross, B. C. S., McKibbin, C., Callan, A. C., Roboti, P., Piacenti, M., Rabu, C., Swanton, E. (2009). Eeyarestatin I inhibits Sec61-mediated protein translocation at the endoplasmic reticulum. Journal of Cell Science, 122(Pt 23), 4393-4400.

Cunningham, A. B., University of, N., \& Institute of Natural, R. (1988). An investigation of the herbal medicine trade in Natal/Kwazulu. Pietermaritzburg: Institute of Natural Resources, University of Natal.

Dambatta, S. H., \& Aliyu, B. S. (2012). A Survey of Major Ethno Medicinal Plants of Kano North, Nigeria, Their Knowledge and Uses by Traditional Healers (Vol. 4).

de Bari, L., Scirè, A., Minnelli, C., Cianfruglia, L., Kalapos, M. P., \& Armeni, T. (2021). Interplay among Oxidative Stress, Methylglyoxal Pathway and S-Glutathionylation. Antioxidants, 10(1), 19. Retrieved from https://www.mdpi.com/2076-3921/10/1/19

DeRisi, J., van den Hazel, B., Marc, P., Balzi, E., Brown, P., Jacq, C., \& Goffeau, A. (2000). Genome microarray analysis of transcriptional activation in multidrug resistance yeast mutants. FEBS Lett, 470(2), 156-160.

Dikalov, S. I., \& Harrison, D. G. (2014). Methods for detection of mitochondrial and cellular reactive oxygen species. Antioxidants \& redox signaling, 20(2), 372-382.

Domínguez, J. M., \& Martín, J. J. (1998). Identification of Elongation Factor 2 as the Essential Protein Targeted by Sordarins in $<\mathrm{em}>$ Candida albicans $</ \mathrm{em}>$. Antimicrobial Agents and Chemotherapy, 42(9), 2279-2283.

Dvorkin-Camiel, L., \& Whelan, J. S. (2008). Tropical American Plants in the Treatment of Infectious Diseases. Journal of Dietary Supplements, 5(4), 349-372.

Eloff, J. N., Katerere, D. R., \& McGaw, L. J. (2008). The Biological Activity and Chemistry of the Southern African Combretaceae. J Ethnopharmacol, 119(3), 686-699.

Fabricant, D. S., \& Farnsworth, N. R. (2001). The value of plants used in traditional medicine for drug discovery. Environmental Health Perspectives, 109 Suppl 1(Suppl 1), 69-75.

Fagone, P., \& Jackowski, S. (2009). Membrane phospholipid synthesis and endoplasmic reticulum function. Journal of Lipid Research, 50 Suppl(Suppl), S311-S316.

Fischli, A. E., Pandit, U. K., \& Black, D. S. (2002). Pure Appl. Chem., 74, 697.

Fokunang, C. N., Ndikum, V., Tabi, O. Y., Jiofack, R. B., Ngameni, B., Guedje, N. M., . . . Kamsu, K. (2011). Traditional Medicine: Past, Present and Future Research and Development Prospects and Integration in the National Health System of Cameroon. African Journal of Traditional, Complementary, And Alternative Medicines : AJTCAM, 8(3), 284-295.

Geldenhuys, C., \& Wyk, B. E. (2002). Indigenous Biological Resources of Africa. In (pp. pp. 116-132).

Giaever, G., Flaherty, P., Kumm, J., Proctor, M., Nislow, C., Jaramillo, D. F., Davis, R. W. (2004). Chemogenomic Profiling: Identifying the Functional Interactions of Small Molecules in Yeast. Proc Natl Acad Sci US A, 101(3), 793-798. 
Giaever, G., \& Nislow, C. (2014). The Yeast Deletion Collection: A Decade of Functional Genomics. Genetics, 197(2), 451-465.

Gibbons, J. J., Abraham, R. T., \& Yu, K. (2009). Mammalian Target of Rapamycin: Discovery of Rapamycin Reveals a Signaling Pathway Important for Normal and Cancer Cell Growth. Semin Oncol, 36 Suppl 3, S3-s17.

Gietz, R. D., \& Schiestl, R. H. (2007). High-efficiency Yeast Transformation Using the LiAc/SS carrier DNA/PEG method. Nat Protoc, 2(1), 31-34.

Gqaleni, N., Ngcobo, M., Parboosing, R., \& Naidoo, A. (2012). In vitro testing of African traditional medicines for cytotoxic, immune modulatory and anti-HIV activities. Afr $J$ Tradit Complement Altern Med, 9 (3 Suppl), 2-11.

Gray, E., Ginty, M., Kemp, K., Scolding, N., \& Wilkins, A. (2012). The PPAR-gamma agonist pioglitazone protects cortical neurons from inflammatory mediators via improvement in peroxisomal function. Journal of Neuroinflammation, 9(1), 63.

Grotzke, J. E., Kozik, P., Morel, J.-D., Impens, F., Pietrosemoli, N., Cresswell, P., Demangel, C. (2017). Sec61 blockade by mycolactone inhibits antigen cross-presentation independently of endosome-to-cytosol export. Proceedings of the National Academy of Sciences, 114(29), E5910. doi:10.1073/pnas.1705242114

Harrison, C. (2014). Patenting natural products just got harder. Nat Biotechnol, 32(5), 403-404.

Harvey, A. L. (2008). Natural products in drug discovery. Drug Discovery Today, 13(19), 894901.

Harvey, A. L., Edrada-Ebel, R., \& Quinn, R. J. (2015). The re-emergence of natural products for drug discovery in the genomics era. Nature Reviews Drug Discovery, 14(2), 111129.

He, Y., Zhou, C., Huang, M., Tang, C., Liu, X., Yue, Y., Liu, D. (2020). Glyoxalase system: A systematic review of its biological activity, related-diseases, screening methods and small molecule regulators. Biomedicine \& Pharmacotherapy, 131, 110663.

Henneberry, A. L., \& Sturley, S. L. (2005). Sterol homeostasis in the budding yeast, Saccharomyces cerevisiae. Semin Cell Dev Biol, 16(2), 155-161.

Hosoda, F., Arai, Y., Okada, N., Shimizu, H., Miyamoto, M., Kitagawa, N., Shibata, T. (2015). Integrated Genomic and Functional Analyses Reveal Glyoxalase I as a Novel Metabolic Oncogene in Human Gastric Cancer. Oncogene, 34(9), 1196-1206.

Huang, J., Wu, S., Barrera, J., Matthews, K., \& Pan, D. (2005). The Hippo Signaling Pathway Coordinately Regulates Cell Proliferation and Apoptosis by Inactivating Yorkie, the Drosophila Homolog of YAP. Cell, 122(3), 421-434.

Jennings, S. M., Tsay, Y. H., Fisch, T. M., \& Robinson, G. W. (1991). Molecular cloning and characterization of the yeast gene for squalene synthetase. Proc Natl Acad Sci U S A, 88(14), 6038-6042.

Jonikas, M. C., Collins, S. R., Denic, V., Oh, E., Quan, E. M., Schmid, V., Schuldiner, M. (2009). Comprehensive Characterization of Genes Required for Protein Folding in the Endoplasmic Reticulum. Science, 323(5922), 1693.

Joo, Y. E. (2014). Natural product-derived drugs for the treatment of inflammatory bowel diseases. Intest Res, 12(2), 103-109. doi:10.5217/ir.2014.12.2.103

Jordá, T., \& Puig, S. (2020). Regulation of ergosterol biosynthesis in saccharomyces cerevisiae. Genes, 11(7), 795.

Justice, M. C., Hsu, M.-J., Tse, B., Ku, T., Balkovec, J., Schmatz, D., \& Nielsen, J. (1998). Elongation Factor 2 as a Novel Target for Selective Inhibition of Fungal Protein Synthesis. Journal of Biological Chemistry, 273(6), 3148-3151.

Kaiser, R. B., \& White, R. P. (2008). Strength test: Debunking an unbalanced approach to development. Leadership in Action, 28(5), 8-12. 
Kao, R. Y., Yang, D., Lau, L. S., Tsui, W. H., Hu, L., Dai, J., Yuen, K. Y. (2010). Identification of influenza A nucleoprotein as an antiviral target. Nat Biotechnol, 28(6), 600-605.

Karst, F., \& Lacroute, F. (1977). Ergosterol biosynthesis inSaccharomyces cerevisiae. Molecular and General Genetics MGG, 154(3), 269-277.

Karst, F., \& Lacroute, F. (1977). Ertosterol biosynthesis in Saccharomyces cerevisiae: mutants deficient in the early steps of the pathway. Mol Gen Genet, 154(3), 269-277.

Karunamoorthi, K., Jegajeevanram, K., Vijayalakshmi, J., \& Mengistie, E. (2013). Traditional Medicinal Plants:A Source of Phytotherapeutic Modality in Resource-Constrained Health Care Settings. J Evid Based Complementary Altern Med, 18(1), 67-74.

Katz, L., \& Baltz, R. H. (2016). Natural product discovery: past, present, and future. $J$ Ind Microbiol Biotechnol, 43(2-3), 155-176.

Kingston, D. G. I., \& Newman, D. (2002). J. Curr. Opin. Drug Discovery Dev., 5, 304.

Klein, W., Westendorf, C., Schmidt, A., Conill-Cortés, M., Rutz, C., Blohs, M., Schülein, R. (2015). Defining a Conformational Consensus Motif in Cotransin-Sensitive Signal Sequences: A Proteomic and Site-Directed Mutagenesis Study. PLOS ONE, 10(3), e0120886.

Klug, L., \& Daum, G. (2014). Yeast lipid metabolism at a glance. FEMS Yeast Research, 14(3), 369-388.

Kolaczkowska, A., \& Goffeau, A. (1999). Regulation of pleiotropic drug resistance in yeast. Drug Resistance Updates, 2(6), 403-414.

Kolaczkowska, A., \& Goffeau, A. (1999). Regulation of pleiotropic drug resistance in yeast. Drug Resist Updat, 2(6), 403-414.

Krikler, D. M. (1985). Withering and the foxglove: the making of a myth. Br Heart J, 54(3), 256-257.

Kuete, V., Fankam, A. G., Wiench, B., \& Efferth, T. (2013). Cytotoxicity and Modes of Action of the Methanol Extracts of Six Cameroonian Medicinal Plants against MultidrugResistant Tumor Cells. Evid Based Complement Alternat Med, 2013, 285903.

Laher, F., Aremu, A. O., Van Staden, J., \& Finnie, J. F. (2013). Evaluating the effect of storage on the biological activity and chemical composition of three South African medicinal plants. South African Journal of Botany, 88, 414-418.

Lahlou, M. (2013). The Success of Natural Products in Drug Discovery. Pharmacology \&amp; Pharmacy, Vol.04No.03, 15.

Lamb, D. C., Kelly, D. E., Manning, N. J., Kaderbhai, M. A., \& Kelly, S. L. (1999). Biodiversity of the P450 catalytic cycle: yeast cytochrome b 5/NADH cytochrome b 5 reductase complex efficiently drives the entire sterol 14-demethylation (CYP51) reaction. FEBS Letters, 462(3), 283-288.

Lee, A. Y., St Onge, R. P., Proctor, M. J., Wallace, I. M., Nile, A. H., Spagnuolo, P. A., Giaever, G. (2014). Mapping the cellular response to small molecules using chemogenomic fitness signatures. Science, 344(6180), 208-211.

Lee, J. A., Uhlik, M. T., Moxham, C. M., Tomandl, D., \& Sall, D. J. (2012). Modern Phenotypic Drug Discovery Is a Viable, Neoclassic Pharma Strategy. Journal of Medicinal Chemistry, 55(10), 4527-4538.

Lenci, E., Innocenti, R., Menchi, G., \& Trabocchi, A. (2018). Diversity-Oriented Synthesis and Chemoinformatic Analysis of the Molecular Diversity of $\mathrm{sp}(3)$-Rich Morpholine Peptidomimetics. Frontiers in chemistry, 6, 522-522.

Li, F., Wang, Y., Li, D., Chen, Y., \& Dou, Q. P. (2019). Are we seeing a resurgence in the use of natural products for new drug discovery? Expert Opinion on Drug Discovery, 14(5), 417-420.

Li, F., Wang, Y., Li, D., Chen, Y., \& Dou, Q. P. (2019). Are we seeing a resurgence in the use of natural products for new drug discovery? Expert Opin Drug Discov, 14(5), 417-420. 
Li, J., Yuan, Z., \& Zhang, Z. (2010). The cellular robustness by genetic redundancy in budding yeast. PLoS genetics, 6(11), e1001187-e1001187. doi:10.1371/journal.pgen.1001187

Li, J. W. H., \& Vederas, J. C. (2009). Drug Discovery and Natural Products: End of an Era or an Endless Frontier? Science, 325(5937), 161.

Liu, C., Apodaca, J., Davis, L. E., \& Rao, H. (2007). Proteasome inhibition in wild-type yeast Saccharomyces cerevisiae cells. BioTechniques, 42(2), 158-162.

Liu, W., Li, L., Ye, H., Chen, H., Shen, W., Zhong, Y., He, H. (2017). From Saccharomyces cerevisiae to human: The important gene co-expression modules. Biomed Rep, 7(2), 153-158.

Liu, Y., Law, B. K., \& Luesch, H. (2009). Apratoxin A Reversibly Inhibits the Secretory Pathway by Preventing Cotranslational Translocation. Molecular Pharmacology, $76(1), 91$.

Louvel, S., Moodley, N., Seibert, I., Steenkamp, P., Nthambeleni, R., Vidal, V., Klimkait, T. (2013). Identification of compounds from the plant species Alepidea amatymbica active against HIV. South African Journal of Botany, 86, 9-14.

Madikizela, B., Ndhlala, A. R., Rengasamy, K. R. R., McGaw, L. J., \& Van Staden, J. (2017). Pharmacological evaluation of two South African commercial herbal remedies and their plant constituents. South African Journal of Botany, 111, 291-298.

Mangoale, R. M., \& Afolayan, A. J. (2020). Comparative Phytochemical Constituents and Antioxidant Activity of Wild and Cultivated Alepidea amatymbica Eckl \& Zeyh. BioMed research international, 2020, 5808624-5808624.

Mangoale, R. M., \& Afolayan, A. J. (2020). Comparative Phytochemical Constituents and Antioxidant Activity of Wild and Cultivated Alepidea amatymbica Eckl \& Zeyh. BioMed Research International, 2020.

Maroyi, A. (2008). Ethnobotanical study of two threatened medicinal plants in Zimbabwe. International Journal of Biodiversity Science \& Management, 4(3), 148-153.

Martin, Y. C., Kofron, J. L., \& Traphagen, L. M. (2002). Do Structurally Similar Molecules Have Similar Biological Activity? Journal of Medicinal Chemistry, 45(19), 4350-4358.

Martins, D., \& English, A. M. (2014). SOD1 oxidation and formation of soluble aggregates in yeast: relevance to sporadic ALS development. Redox biology, 2, 632-639.

Mateja, A., \& Keenan, R. J. (2018). A structural perspective on tail-anchored protein biogenesis by the GET pathway. Current Opinion in Structural Biology, 51, 195-202.

Mathur, S., \& Hoskins, C. (2017). Drug development: Lessons from nature. Biomed Rep, 6(6), 612-614.

Mbaveng, A. T., Kuete, V., \& Efferth, T. (2017). Potential of Central, Eastern and Western Africa Medicinal Plants for Cancer Therapy: Spotlight on Resistant Cells and Molecular Targets. Front Pharmacol, 8, 343.

McKenna, M., Simmonds, R. E., \& High, S. (2016). Mechanistic insights into the inhibition of Sec61-dependent co- and post-translational translocation by mycolactone. Journal of Cell Science, 129(7), 1404.

Mohs, R. C., \& Greig, N. H. (2017). Drug discovery and development: Role of Basic Biological Research. Alzheimers Dement (N Y), 3(4), 651-657.

Monciardini, P., Iorio, M., Maffioli, S., Sosio, M., \& Donadio, S. (2014). Discovering new Bioactive Molecules from Microbial Sources. Microb Biotechnol, 7(3), 209-220.

Monteiro, P. T., Oliveira, J., Pais, P., Antunes, M., Palma, M., Cavalheiro, M., Teixeira, M. C. (2019). YEASTRACT+: a portal for cross-species comparative genomics of transcription regulation in yeasts. Nucleic Acids Research, 48(D1), D642-D649.

Morales, F., Padilla, S., \& Falconi, F. (2017). MEDICINAL PLANTS USED IN TRADITIONAL HERBAL MEDICINE IN THE PROVINCE OF CHIMBORAZO, ECUADOR. Afr J Tradit Complement Altern Med, 14(1), 10-15. 
Moreno, S., \& Cerù, M. (2015). In search for novel strategies towards neuroprotection and neuroregeneration: is PPAR\&\#945; a promising therapeutic target? Neural Regeneration Research, 10(9), 1409-1412.

Morikawa, T., Xu, F., Kashima, Y., Matsuda, H., Ninomiya, K., \& Yoshikawa, M. (2004). Novel Dolabellane-Type Diterpene Alkaloids with Lipid Metabolism Promoting Activities from the Seeds of Nigella sativa. Organic Letters, 6(6), 869-872.

Mulaudzi, R. B., Ndhlala, A. R., Finnie, J. F., \& Van Staden, J. (2009). Antimicrobial, antiinflammatory and genotoxicity activity of Alepidea amatymbica and Alepidea natalensis (Apiaceae). South African Journal of Botany, 75(3), 584-587.

Muleya, E., Joseph, O., Mtunzi, F., \& Sekomeng, M. (2017). Diterpenoids of Alepidea amatymbica eckl. \& zeyh: studies of their cytotoxic, antimicrobial and lipoxygenase inhibitory activities. MOJ Biorg Org Chem, 1(3), 103-111.

Muleya, E., Joseph, O. B., Mtunzi, F., \& Sekomeng, M. J. (2017). Diterpenoids of alepidea amatymbica eckl. \& zeyh: Studies of Their Cytotoxic, Antimicrobial, And Lipoxygenase Inhibitory Activities.

Neuwinger, H. D. (2000). African Traditional Medicine. A Dictionary of Plant Use and Applications.

Newman, D. J., \& Cragg, G. M. (2007). Natural Products as Sources of New Drugs over the last 25 years. $J$ Nat Prod, 70(3), 461-477.

Newman, D. J., \& Cragg, G. M. (2016). Natural Products as Sources of New Drugs from 1981 to 2014. J Nat Prod, 79(3), 629-661.

Newman, D. J., \& Cragg, G. M. (2020). Natural Products as Sources of New Drugs over the Nearly Four Decades from 01/1981 to 09/2019. J Nat Prod, 83(3), 770-803.

Ngouana, V., Fokou, P. V., Foudjo, B. U., Ngouela, S. A., Boyom, F. F., \& Zollo, P. H. (2011). Antifungal activity and acute toxicity of stem bark extracts of Drypetes gossweileri S. Moore-euphorbiaceae from Cameroon. Afr J Tradit Complement Altern Med, 8(3), 328333.

O' Connor, C. J., Laraia, L., \& Spring, D. R. (2011). Chemical genetics. Chemical Society Reviews, 40(8), 4332-4345.

Ocloo, A., \& Dongdem, J. T. (2011). Mitochondria as pharmacological targets: the discovery of novel anti-obesity mitochondrial uncouplers from Africa's Medicinal plants. African Journal of Traditional, Complementary, and Alternative Medicines : AJTCAM, 9(2), 256-259.

Odeyemi, S., \& Bradley, G. (2018). Medicinal Plants Used for the Traditional Management of Diabetes in the Eastern Cape, South Africa: Pharmacology and Toxicology. Molecules (Basel, Switzerland), 23(11), 2759.

Okesli, A., Khosla, C., \& Bassik, M. C. (2017). Human Pyrimidine Nucleotide Biosynthesis as a Target for Antiviral Chemotherapy. Current Opinion in Biotechnology, 48, 127-134.

Okoli, B., \& Mtunzi, F. (2017). Diterpenoids of Alepidea Amatymbica Eckl. \& Zeyh: Studies of Their Cytotoxic, Antimicrobial, and Lipoxygenase Inhibitory Activities (Vol. 1).

Otang, W. M., Grierson, D. S., \& Ndip, R. N. (2012). Phytochemical studies and antioxidant activity of two South African medicinal Plants Traditionally used for the management of opportunistic Fungal infections in HIV/AIDS patients. BMC Complementary and Alternative Medicine, 12(1), 43.

Otang, W. M., Grierson, D. S., \& Ndip, R. N. (2014). Cytotoxicity of Three South African Medicinal Plants using the Chang liver cell line. Afr J Tradit Complement Altern Med, 11(2), 324-329.

Oyagbemi, A. A., Adebiyi, O. E., Adigun, K. O., Ogunpolu, B. S., Falayi, O. O., Hassan, F. O., Yakubu, M. A. (2020). Clofibrate, a PPAR- $\alpha$ agonist, abrogates sodium fluoride- 
induced neuroinflammation, oxidative stress, and motor incoordination via modulation of GFAP/Iba-1/anti-calbindin signaling pathways. Environ Toxicol, 35(2), 242-253.

Oyedemi, S., Bradley, G., \& Afolayan, A. (2010). In-vitro and-vivo antioxidant activities of aqueous extract of Strychnos henningsii Gilg. African Journal of Pharmacy and Pharmacology, 4(2), 070-078.

Pan, M., Jiao, S., Reinach, P. S., Yan, J., Yang, Y., Li, Q., . . Zhou, X. (2018). Opposing Effects of PPAR $\alpha$ Agonism and Antagonism on Refractive Development and Form Deprivation Myopia in Guinea Pigs. Investigative Ophthalmology \& Visual Science, 59(15), 5803-5815.

Pannunzio, V. G., Burgos, H. I., Alonso, M., Mattoon, J. R., Ramos, E. H., \& Stella, C. A. (2004). A Simple Chemical Method for Rendering Wild-Type Yeast Permeable to Brefeldin A That Does Not Require the Presence of an Erg6 Mutation. Journal of Biomedicine \& Biotechnology, 2004(3), 150-155.

Papagiannidis, D., Bircham, P. W., Luechtenborg, C., Ruffini, G., Bruegger, B., \& Schuck, S. (2021). Ice 2 promotes ER membrane biogenesis in yeast by inhibiting the conserved lipin phosphatase complex. BioRxiv, 2020.2002.2023.961722.

Parsons, A. B., Brost, R. L., Ding, H., Li, Z., Zhang, C., Sheikh, B., Boone, C. (2004). Integration of Chemical-Genetic and Genetic Interaction data links bioactive Compounds to Cellular Target Pathways. Nat Biotechnol, 22(1), 62-69.

Parsons, A. B., Lopez, A., Givoni, I. E., Williams, D. E., Gray, C. A., Porter, J., Boone, C. (2006). Exploring the mode-of-action of bioactive compounds by chemical-genetic profiling in yeast. Cell, 126(3), 611-625.

Patel, A., Antonopoulou, I., Enman, J., Rova, U., Christakopoulos, P., \& Matsakas, L. (2019). Lipids detection and quantification in oleaginous microorganisms: An Overview of the Current State of the Art. BMC Chemical Engineering, 1(1), 13.

Patel, S. S., Raghuwanshi, R., Masood, M., Acharya, A., \& Jain, S. K. (2018). Medicinal plants with Acetylcholinesterase Inhibitory Activity. Rev Neurosci, 29(5), 491-529.

Patridge, E., Gareiss, P., Kinch, M. S., \& Hoyer, D. (2016). An Analysis of FDA-approved Drugs: Natural Products and their Derivatives. Drug Discovery Today, 21(2), 204-207.

Peretti, D., Dahan, N., Shimoni, E., Hirschberg, K., \& Lev, S. (2008). Coordinated lipid transfer between the Endoplasmic Reticulum and the Golgi complex requires the VAP proteins and is essential for Golgi-mediated transport. Mol Biol Cell, 19(9), 3871-3884.

Permin, H., Norn, S., Kruse, E., \& Kruse, P. R. (2016). On the history of Cinchona bark in the treatment of Malaria. Dan Medicinhist Arbog, 44, 9-30.

Piotrowski, J. S., Li, S. C., Deshpande, R., Simpkins, S. W., Nelson, J., Yashiroda, Y., Boone, C. (2017). Functional annotation of chemical libraries across diverse biological processes. Nat Chem Biol, 13(9), 982-993.

Piotrowski, J. S., Li, S. C., Deshpande, R., Simpkins, S. W., Nelson, J., Yashiroda, Y., Boone, C. (2017). Functional annotation of chemical libraries across diverse biological processes. Nature Chemical Biology, 13(9), 982-993.

Pongcharoen, W., Rukachaisirikul, V., Phongpaichit, S., Kühn, T., Pelzing, M., Sakayaroj, J., \& Taylor, W. C. (2008). Metabolites from the Endophytic Fungus Xylaria sp. PSUD14. Phytochemistry, 69(9), 1900-1902.

Potenza, M., Bowser, R., Müller, H., \& Novick, P. (1992). SEC6 encodes an 85 kDa soluble protein required for exocytosis in yeast. Yeast, 8(7), 549-558.

Rabu, C., Schmid, V., Schwappach, B., \& High, S. (2009). Biogenesis of tail-anchored proteins: the beginning for the end? Journal of Cell Science, 122(20), 3605-3612.

Ravishankar, B., \& Shukla, V. J. (2007). Indian systems of medicine: a brief profile. Afr $J$ Tradit Complement Altern Med, 4(3), 319-337. 
Reynolds, A., Lundblad, V., Dorris, D., \& Keaveney, M. (1997). Yeast Vectors and Assays for Expression of Cloned Genes. Current Protocols in Molecular Biology, 39(1), 13.16.1113.16.16.

Rosén, J., Gottfries, J., Muresan, S., Backlund, A., \& Oprea, T. I. (2009). Novel chemical space exploration via natural products. Journal of Medicinal Chemistry, 52(7), 1953-1962.

Rustaiyan, A., \& Sadjadi, A. S. (1987). Kaurene derivatives from Alepidea amatynsia. Phytochemistry.

Schmidt, R. M., Schessner, J. P., Borner, G. H., \& Schuck, S. (2019). The proteasome biogenesis regulator Rpn4 cooperates with the unfolded protein response to promote ER stress resistance. Elife, 8.

Schuck, S., Prinz, W. A., Thorn, K. S., Voss, C., \& Walter, P. (2009). Membrane expansion alleviates endoplasmic reticulum stress independently of the unfolded protein response. J Cell Biol, 187(4), 525-536.

Schuldiner, M., Metz, J., Schmid, V., Denic, V., Rakwalska, M., Schmitt, H. D., Weissman, J. S. (2008). The GET Complex Mediates Insertion of Tail-Anchored Proteins into the ER membrane. Cell, 134(4), 634-645.

Shah, P., Ding, Y., Niemczyk, M., Kudla, G., \& Plotkin, Joshua B. (2013). Rate-Limiting Steps in Yeast Protein Translation. Cell, 153(7), 1589-1601.

Simpkins, S. W., Nelson, J., Deshpande, R., Li, S. C., Piotrowski, J. S., Wilson, E. H., Myers, C. L. (2018). Predicting bioprocess targets of chemical compounds through integration of chemical-genetic and genetic interactions. PLOS Computational Biology, 14(10), e1006532.

Simpson, P. J., Schwappach, B., Dohlman, H. G., \& Isaacson, R. L. (2010). Structures of Get3, Get4, and Get5 Provide New Models for TA Membrane Protein Targeting. Structure, $18(8), 897-902$.

Sinha, S., \& Vohora, D. (2018). Chapter 2 Drug Discovery and Development: An Overview.

Snapka, R. M., Woo, S. H., Blokhin, A. V., \& Witiak, D. T. (1996). Inhibition of topoisomerase II by ICRF-193, the meso isomer of 2,3-bis(2,6-dioxopiperazin-4-yl)butane. Critical dependence on 2,3-butanediyl linker absolute configuration. Biochem Pharmacol, $52(4), 543-549$.

Sobanski, M. A., \& Dickinson, J. R. (1995). A simple method for the direct extraction of plasmid DNA from yeast. Biotechnology Techniques, 9(3), 225-230.

Stafford, G. I., Jager, A. K., \& van Staden, J. (2005). Activity of traditional South African sedative and potentially CNS-acting plants in the GABA-benzodiazepine receptor assay. J Ethnopharmacol, 100(1-2), 210-215.

Street, R. A., \& Prinsloo, G. (2013). Commercially Important Medicinal Plants of South Africa: A Review. Journal of Chemistry, 2013, 1-16.

Stukey, J. E., McDonough, V. M., \& Martin, C. E. (1989). Isolation and characterization of OLE1, a gene affecting fatty acid desaturation from Saccharomyces cerevisiae. J Biol Chem, 264(28), 16537-16544.

Sunday Uko, M., Usman, A., Toma, I., E Okhale, S., T Magili, S., \& Adzu, B. (2019). Evaluation of Active Phytochemical Constituents Linked to the Analgesic and AntiInflammatory Property of Cassia Singueana Del. Root Bark.

Tashiro, E., \& Imoto, M. (2012). Target identification of bioactive compounds. Bioorganic \& Medicinal Chemistry, 20(6), 1910-1921.

Thayer, P. W., \& Austin, J. T. (1992). Harold E. Burtt (1890-1991): Obituary. American Psychologist, 47(12), 1677-1677.

Thirugnanasampandan, R., Jayakumar, R., Narmatha Bai, V., Martin, E., \& Rajendra Prasad, K. J. (2008). Antiacetylcholinesterase and antioxidant ent -Kaurene diterpenoid, 
melissoidesin from Isodon wightii (Bentham) H. Hara. Natural Product Research, 22(8), 681-688.

Thomford, N. E., Senthebane, D. A., Rowe, A., Munro, D., Seele, P., Maroyi, A., \& Dzobo, K. (2018). Natural Products for Drug Discovery in the 21 st Century: Innovations for Novel Drug Discovery. Int J Mol Sci, 19(6).

Thomford, N. E., Senthebane, D. A., Rowe, A., Munro, D., Seele, P., Maroyi, A., \& Dzobo, K. (2018). Natural Products for Drug Discovery in the 21 st Century: Innovations for Novel Drug Discovery. International Journal of Molecular Sciences, 19(6), 1578.

Tkach, J. M., Yimit, A., Lee, A. Y., Riffle, M., Costanzo, M., Jaschob, D., Brown, G. W. (2012). Dissecting DNA damage response pathways by analysing protein localization and abundance changes during DNA replication stress. Nature Cell Biology, 14(9), 966976.

Tong, A. H. Y., \& Boone, C. (2007). 16 high-throughput strain construction and systematic synthetic lethal screening in Saccharomycescerevisiae. Methods in Microbiology, 36, 369-707.

Treco, D. A., \& Winston, F. (2008). Growth and Manipulation of Yeast. Current Protocols in Molecular Biology, 82(1), 13.12.11-13.12.12.

Truan, G., Epinat, J.-C., Rougeulle, C., Cullin, C., \& Pompon, D. (1994). Cloning and characterization of a yeast cytochrome b5-encoding gene which suppresses ketoconazole hypersensitivity in a NADPH-P-450 reductase-deficient strain. Gene, 142(1), 123-127.

Tshikalange, T. E., Mophuting, B. C., Mahore, J., Winterboer, S., \& Lall, N. (2016). An Ethnobotanical Study of Medicinal plants used in Villages under Jongilanga Tribal Council Mpumalanga, South Africa. Afr J Tradit Complement Altern Med, 13(6), 8389.

Usaj, M., Tan, Y., Wang, W., VanderSluis, B., Zou, A., Myers, C. L., Boone, C. (2017). TheCellMap.org: A Web-Accessible Database for Visualizing and Mining the Global Yeast Genetic Interaction Network. G3 (Bethesda, Md.), 7(5), 1539-1549.

Usaj, M., Tan, Y., Wang, W., VanderSluis, B., Zou, A., Myers, C. L., Boone, C. (2017). TheCellMap.org: A Web-Accessible Database for Visualizing and Mining the Global Yeast Genetic Interaction Network. G3 (Bethesda), 7(5), 1539-1549.

Van Puyenbroeck, V., \& Vermeire, K. (2018). Inhibitors of Protein Translocation Across Membranes of the Secretory Pathway: Novel Antimicrobial and Anticancer Agents. Cell Mol Life Sci, 75(9), 1541-1558.

van Wyk, B. E. (2008). A broad Review of Commercially Important Southern African Medicinal Plants. J Ethnopharmacol, $119(3), 342-355$.

Vitali, D. G., Sinzel, M., Bulthuis, E. P., Kolb, A., Zabel, S., Mehlhorn, D. G., Rapaport, D. (2018). The GET pathway can increase the risk of mitochondrial outer membrane proteins to be mistargeted to the ER. J Cell Sci, 131(10).

von der Haar, T. (2008). A quantitative estimation of the global translational activity in logarithmically growing yeast cells. BMC Syst Biol, 2, 87.

Wach, A., Brachat, A., Pöhlmann, R., \& Philippsen, P. (1994). New heterologous modules for classical or PCR-based gene disruptions in Saccharomyces cerevisiae. Yeast, 10(13), 1793-1808.

Wagih, O., Usaj, M., Baryshnikova, A., VanderSluis, B., Kuzmin, E., Costanzo, M., Parts, L. (2013). SGAtools: one-stop analysis and visualization of array-based genetic interaction screens. Nucleic acids research, 41(W1), W591-W596.

Wagih, O., Usaj, M., Baryshnikova, A., VanderSluis, B., Kuzmin, E., Costanzo, M., Parts, L. (2013). SGAtools: one-stop analysis and visualization of array-based genetic interaction screens. Nucleic Acids Research, 41(Web Server issue), W591-596. 
Wang, W.-Y., Zhou, H., Wang, Y.-F., Sang, B.-S., \& Liu, L. (2020). Current Policies and Measures on the Development of Traditional Chinese Medicine in China. Pharmacological Research, 105187-105187.

Weill, U., Yofe, I., Sass, E., Stynen, B., Davidi, D., Natarajan, J., Schuldiner, M. (2018). Genome-wide SWAp-Tag yeast libraries for proteome exploration. Nature methods, 15(8), 617-622.

Wintola, O., \& Afolayan, A. (2014). Alepidea amatymbica Eckl. \& Zeyh.: A Review of Its Traditional Uses, Phytochemistry, Pharmacology, and Toxicology (Vol. 2014).

Wintola, O. A., \& Afolayan, A. J. (2014). Alepidea amatymbica Eckl. \& Zeyh.: A Review of Its Traditional Uses, Phytochemistry, Pharmacology, and Toxicology. Evid Based Complement Alternat Med, 2014, 284517.

Wintola, O. A., \& Afolayan, A. J. (2014). $<\mathrm{i}>$ Alepidea amatymbica $</ \mathrm{i}>$ Eckl. \& Zeyh.: A Review of Its Traditional Uses, Phytochemistry, Pharmacology, and Toxicology. Evidence-Based Complementary and Alternative Medicine, 2014, 284517.

Wirth, A., Jung, M., Bies, C., Frien, M., Tyedmers, J., Zimmermann, R., \& Wagner, R. (2003). The Sec61p complex is a dynamic precursor activated channel. Mol Cell, 12(1), 261268.

Wohlleben, W., Mast, Y., Stegmann, E., \& Ziemert, N. (2016). Antibiotic drug discovery. Microb Biotechnol, 9(5), 541-548.

Wohlleben, W., Mast, Y., Stegmann, E., \& Ziemert, N. (2016). Antibiotic drug discovery. Microb Biotechnol, 9(5), 541-548.

Wyk, B. E. v., \& Gericke, N. (2000). People's Plants: A Guide to Useful Plants of Southern Africa. Pretoria: Briza Publications.

Xu, Y., \& Chen, X. (2006). Glyoxalase II, a detoxifying enzyme of glycolysis byproduct methylglyoxal and a target of p63 and p73, is a pro-survival factor of the p53 family. The Journal of Biological Chemistry, 281(36), 26702-26713.

Yilmaz, E., \& Karadeniz, F. (2014). Effect of storage on the bioactive compounds and Antioxidant Activity of Quince Nectar. International Journal of Food Science \& Technology, 49(3), 718-725.

Yuan, H., Ma, Q., Ye, L., \& Piao, G. (2016). The Traditional Medicine and Modern Medicine from Natural Products. Molecules, 21(5), 559.

Zarins-Tutt, J. S., Barberi, T. T., Gao, H., Mearns-Spragg, A., Zhang, L., Newman, D. J., \& Goss, R. J. M. (2016). Prospecting for new bacterial metabolites: A Glossary of Approaches for Inducing, Activating and Upregulating the Biosynthesis of Bacterial Cryptic or Silent Natural Products. Nat Prod Rep, 33(1), 54-72.

Zhang, Y., De Laurentiis, E., Bohnsack, K. E., Wahlig, M., Ranjan, N., Gruseck, S., Rospert, S. (2021). Ribosome-bound Get $4 / 5$ facilitates the Capture of Tail-Anchored Proteins by Sgt2 in yeast. Nat Commun, 12(1), 782. 